Geology and Fuel

Resources of the

Green River Formation

Southeastern Uinta Basin

Utah and Colorado

By W. B. CASHION

GEOLOGICAL SURVEY PROFESSIONAL PAPER 548

$A$ study of the Green River Formation in

a 2,300-square-mile area in northeastern

Utah and northwestern Colorado

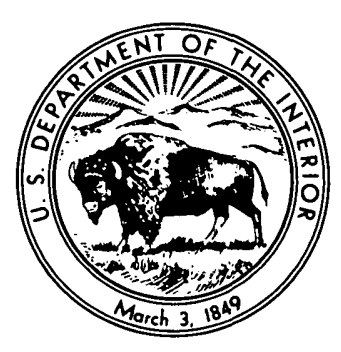

UNITED STATES GOVERNMENT PRINTING OFFICE, WASHINGTON : 1967 


\section{UNITED STATES DEPARTMENT OF THE INTERIOR \\ STEWART L. UDALL, Secretary \\ GEOLOGIGAL SURVEY \\ William T. Pecora, Director}

Library of Congress catulog-card No. GS 67-162

For sale by the Superintendent of Documents, U.S. Government Printing Office Washington, D.C. 20402 


\section{CONTENTS}

Abstract.

Introduction . . . . . .

Locality and regional relations..................

Purpose of investigation . . .

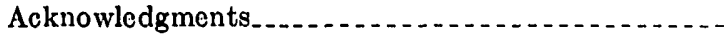

Previous investigations . . .

Present investigation .........

Geography

Topography

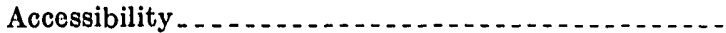

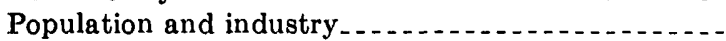

Drainage and water supply . Vegetation

Stratigraphy ...............

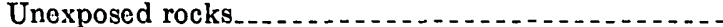

Tertiary System . . . . . . . . . .

Wasatch Formation..............................

Green River Formation

Douglas Creek Member.................

Garden Gulch Member...............

Parachute Creek Member............

Evacuation Creek Member................

Tuff beds in the Green River Formation...

Tuffaceous dikes of the Green River For-

mation.
Stratigraphy-Continued

Tertiary System-Continued Page

Uinta Formation.

Duchesne River Formation _............ 21

Quaternary System

Structure . .

Economic geology

Oil shale $\ldots \ldots \ldots$

Composition and physical characteristics._..... 24

Development.......................... 24

Potential reserves......... 24

Gilsonite

Description and geologic setting .......... 30

Major veins....... 34

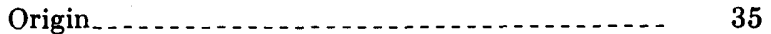

Development

Reserves............ 37

Bituminous sandstones.

Oil and gas. .

Development

Possibilities . .

References.

Index

\section{ILLUSTRATIONS}

[Plates are in pocket]

Plate 1. Geologic map and section of the southeastern part of Uinta Basin.

2. Fence diagram of the Green River Formation and the upper part of the Wasatch Formation in the southeastern part of the Uinta Basin.

3. Stratigraphic sections of the Green River and adjacent formations in the southeastern part of the Uinta Basin.

4. Stratigraphic sections of the Mahogany ledge.

5. Maps showing thickness of selected oil-shale zones.

Figure 1. Map showing area of this report and some adjacent structural and physiographic features.

2-7. Photographs of-

2. Thin beds typical of much of the Green River Formation

3. Green River-Uinta contact near Willow Creek

4. Green River Formation in Hells Hole Canyon and along Hill Creek . . . . . . . . . . . . . . . .

5. Tuffaceous dikes in the Parachute Creek and Evacuation Creek Members...

6. Jointing in the Horse Bench Sandstone Bed of Evacuation Creek Member.....

7. A minor fold in a siltstone bed of the Parachute Creek Member

8. Map showing thickness of oil-shale beds in the Uinta Basin .

9. Map showing location and width of gilsonite veins .

10. Photographs of gilsonite veins..

11. Longitudinal sections of gilsonite veins . .

12. Map showing outcrop of zone containing bituminous sandstone beds 


\section{TABLES}

TABLE 1. Estimated tonnage and potential oil yield of that part of the Mahogany zone and adjacent beds occurring in a continuous sequence at least 15 feet thick and yielding an average of 30 gallons oil per ton............

2. Estimated tonnage and potential oil yield of that part of the Mahogany zone and adjacent beds occurring in a continuous sequence at least 15 feet thick and yielding an average of 25 gallons oil per ton..................

3. Estimated tonnage and potential oil yield of that part of the Mahogany zone and adjacent beds occurring in a continuous sequence at least 15 feet thick and yielding an average of 15 gallons oil per ton...........

4. Estimated original reserves of gilsonite in the mapped area.

5. Exploratory wells drilled within the mapped area $\ldots$

Page 


\title{
GEOLOGY AND FUEL RESOURGES OF THE GREEN RIVER FORMATION SOUTHEASTERN UINTA BASIN, UTAH AND COLORADO
}

\author{
By W. B. Cashion
}

\begin{abstract}
The area of this report is the southeastern part of the Uinta Basin and constitutes about 2,300 square miles in northeastern Utah and northwestern Colorado. The major topographic feature is a north-sloping plateau that is highly dissected by steepwalled canyons. The topography along the southern margin is dominated by the rugged south-facing Roan Cliffs.

Bedrock exposed in the area is of fluvial and lacustrine origin and of Eocene and Oligocene age. The oldest rocks exposed are the massive sandstone and variegated shale of the Wasatch Formation of Eocene age. The Wasatch Formation is divided into the main body and the Renegade Tongue (new name). The Wasatch Formation interfingers with and is overlain by the Green River Formation, also of Eocene age.
\end{abstract}

The Green River Formation has been divided, in ascending order, into the Douglas Creek, Garden Gulch, Parachute Creek, and Evacuation Creek Members. The Douglas Creek Member is composed chiefly of sandstone, siltstone, and algal and oolitic limestone deposited in a nearshore-lacustrine environment. It interfingers with the underlying Wasatch Formation toward the former shore and interfingers with the overlying Garden Gulch and Parachute Creek Members toward the former basin. The Garden Gulch, Parachute Creek, and Evacuation Creek Members are composed chiefly of thin-bedded marlstone, siltstone, and oil shale deposited in a lacustrine environment. The Parachute Creek Member contains the principal oil-shale beds of the Green River Formation. The richest of these beds is the Mahogany oil-shale bed, which lies within a group of rich oil-shale beds that are designated as the Mahogany ledge at the surface and as the Mahogany zone in the subsurface. The Evacuation Creek Member of the Green River Formation is overlain by and interfingers with the Uinta Formation of Eocene age.

The Uinta Formation is composed of massive sandstone and arenaceous shale deposited mainly in a fluvial environment. It contains abundant vertebrate fossils. The Uinta is overlain by the red and gray fluvial sandstones and shales of the Duchesne River Formation of Eocene or Oligocene age.

Most of the mapped area is on the south flank of the Uinta Basin and is underlain by rocks that dip gently north. Steep dips are confined to the northeastern part of the area, where the beds are tilted southwest or west. Neither the density nor the displacements of faults are great. The Green River strata are cut by a prominent system of joints. One joint set trends northwest and the other northeast.

Hydrocarbons, in various forms, are abundant in the mapped area. Oll shale in the Mahogany zone and adjacent beds that yields an average of 15 gallons of oil per ton from a continuous sequence 15 feet or more thick contains an estimated 53 billion barrels of oil. The original reserves of gilsonite in the area are estimated to be about 27 million tons. Oil and gas are produced from Jurassic, Cretaceous, and Tertiary rocks. In the southern part of the area, the Douglas Creek Member contains several sandstones that are impregnated with bitumen.

\section{INTRODUCTION}

\section{LOCALITY AND REGIONAL RELATIONS}

The area described in this report is the southeastern part of the Uinta Basin of northeastern Utah and northwestern Colorado (fig. 1). About 2,150 square miles of the area is in Uintah, Grand, and Carbon Counties, Utah, and about 150 square miles is in Rio Blanco County, Colo. Boundaries of the irregularly shaped area are controlled chiefly by the outcrop of the Green River Formation.

The Uinta Basin, which can be classified as a structural, a depositional, or a topographic basin, has an area of approximately 7,000 square miles, 95 percent of which is in Utah. The maximum dimensions of the basin are about 130 miles from east to west and about 100 miles from north to south. As considered in this report, the basin is bounded on the north by the Uinta Mountains, on the west by the Wasatch Range, on the south by the Roan Cliffs, and on the east by the Douglas Creek arch. The Piceance Creek basin, considered by some geologists to be part of the Uinta Basin, is treated herein as an individual geomorphic subdivision.

Structurally the Uinta Basin is a sharply asymmetric feature that was produced by Laramide orogeny. The axis lies in the northern part of the basin near the Uinta Mountains. On the north flank of the basin, strata of Mesozoic and early Tertiary age dip steeply south and are truncated by more gently dipping strata of late Tertiary age. On the south flank of the basin Mesozoic and lower Tertiary rocks dip gently north, and no upper Tertiary rocks are present.

During Eocene time large amounts of sediment from adjacent topographically high areas were deposited in various types of lacustrine and fluvial environments in the basin. These sediments, which are assigned to the Wasatch, Green River, and Uinta Formations, are perhaps more than 15,000 feet thick near the center of the basin. Although the mapped area is marginal to 


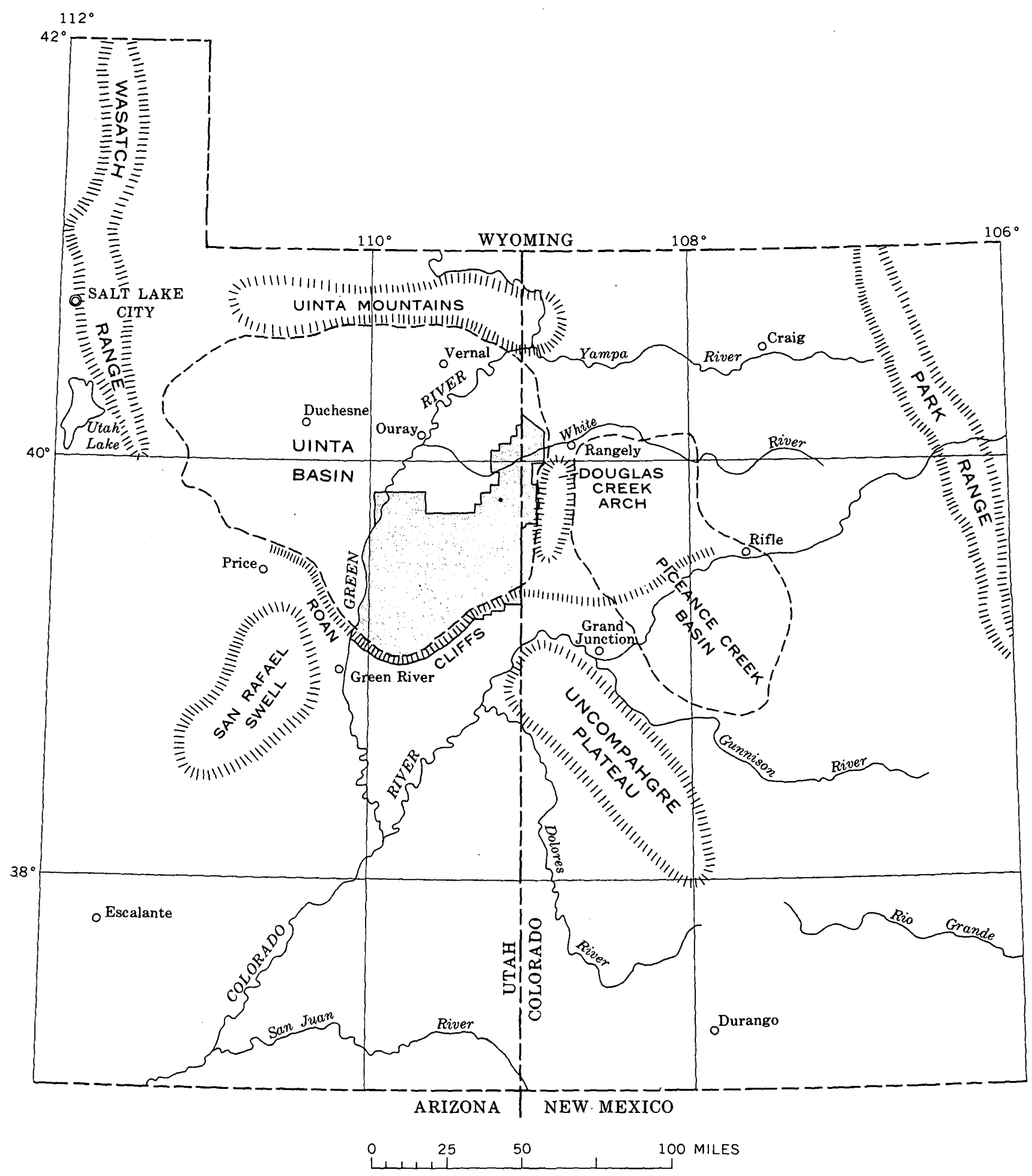

Fraure 1.-Area of this report and some adjacent structural and physiographic features. 
the area of thickest lacustrine deposits, it displays most of the lithologies and stratigraphic relations believed to be present in the deeper part of the lake, as well as beds deposited in nearshore-lacustrine and fluvial environments.

\section{PURPOSE OF INVESTIGATION}

The primary purpose of this investigation was to obtain data on the stratigraphic distribution, continuity, areal extent, thickness, oil content, and attitude of oil-shale beds of the area, in order to estimate the potential oil-shale resources. The occurrence and extent of gilsonite and bituminous sandstones and those factors useful in evaluation of oil and gas possibilities of the area were also studied.

\section{ACKNOWLEDGMENTS}

The author is indebted to the many exploration companies that furnished oil-shale samples from cores and rotary cuttings to the U.S. Bureau of Mines for oilyield assay, and to Mr. K. E. Stanfield, U.S. Bureau of Mines, for furnishing the results of these assays. These data greatly facilitated computation of the potential oilshale resources of the area. Mr. Charles Neal of Vernal, Utah, gave information concerning the gilsonite mining operations, past and present, in the Uinta Basin. R. L. Griggs, U.S. Geological Survey, examined and described the thin sections of the tuffaceous rocks. The hospitality of the residents of the area facilitated the work of the field parties.

\section{PREVIOUS INVESTIGATIONS}

Geologic maps and descriptions of the Tertiary strata in the eastern Uinta Basin were first published in 1878 (Endlich, 1878, p. 78-86; Peale, 1878, p. 174-175, pl. 11; White, 1878, p. 34-39, pl. 2). Eldridge (1896, 1901) investigated the occurrences of gilsonite in the Uinta Basin and also pointed out that the Green River Formation contains "bituminous limestones" having potential economic value $(1896$, p. 923 , table $4 ; 1901$, p. 334, table 4). In 1913 a reconnaissance study of the oil-shale deposits of part of Utah and Colorado was conducted by Woodruff and Day (1915). Winchester, during 1914-18, sampled and analyzed oil-shale beds of the Green River Formation in Colorado and Utah $(1916,1918)$. During 1922-25 W. H. Bradley (1931) made a detailed study of the lithology and paleontology of the Green River Formation in Utah and Colorado. Published studies of the Green River Formation made by Bradley $(1926,1929,1930,1964)$ in Colorado and Wyoming have also led to a better understanding of the formation in the Uinta Basin. Dane $(1954,1955)$ investigated the stratigraphic relations of the Green River and Uinta Formations in part of the western Uinta Basin. Dane's study was made in conjunction with a photogeologic mapping project (Ray and others, 1956). Picard $(1955,1957)$ described the regional subsurface lithology of the Green River Formation.

\section{PRESENT INVESTIGATION}

Geologic investigations of the area described in this report, and shown on the accompanying geologic map (pl. 1), started in June 1951 and continued intermittently until June 1959. About 500 square miles in the northeastern part of the area (areas 1 and 2 of index map on pl. 2) was mapped in 1951 by J. H. Brown, Jr., W. B. Cashion, C. R. Lewis, and J. L. Snider and was described in the text of U.S. Geological Survey Oil and Gas Investigations Map OM-153 (Cashion and Brown, 1956). In 1952, 750 square miles in the central part of the area was mapped by Cashion, L. W. Camp, C. R. Lewis, and R. M. Finks. During 1953 an area of 450 square miles, including part of Naval Oil-Shale Reserve No. 2, was studied by Cashion, Camp, Lewis, J. R. Donnell, H. J. Hyden, R. G. Miller, P. P. Orkild, C. T. Sumsion, and J. C. Benson. A core-drilling program in Naval Oil-Shale Reserve No. 2, supervised by Camp, Cashion, and Donnell, and the geologic mapping were completed in 1954. The report on Naval Oil-Shale Reserve No. 2 was published as U.S. Geological Survey Bulletin 1072-O (Cashion, 1959). In the southernmost part of the Uinta Basin a 400 -square-mile area was investigated by Cashion and A. D. Zapp in 1955, and in 1956 Cashion, assisted by J. M. Baldessari, studied the intertonguing relations between the Green River and Wasatch Formations along the east and southeast edges of the Uinta Basin. During 1957-59 Cashion gathered some additional stratigraphic and structural data.

In addition to the geologic mapping, a major phase of the investigation was the collection and evaluation of subsurface data on potential oil yield of the oil-shale beds. Oil-shale resources of the mapped area have been described in preliminary reports (Cashion, 1957, 1961). These resources are described in detail herein and the oil-shale resources of the entire basin are preliminarily appraised.

Fieldwork consisted of geologic mapping of the report area by use of aerial photographs (scale $1: 31,680$ ), measurement of detailed stratigraphic sections, estimation of potential oil yield, and collection of samples from the oil-shale beds for oil-yield assay. Stratigraphic sections were measured by use of hand level and a 6-foot steel tape. Parts of oil-shale and marlstone beds were chipped clean and examined critically so that the potential oil yield could be estimated. Composite channel samples were subsequently collected from 
GREEN RIVER FORMATION, UTAH AND COLORADO

kerogen-rich oil-shale beds in some of the sections and unweathered samples were obtained from the Naval Oil-Shale Reserve No. 2 by means of core drilling.

Altitudes of key beds in the Green River Formation were determined, for structural control, by use of aneroid barometer or planetable and telescopic alidade. Most distances used in computation of differences in altitude were measured on aerial-photograph mosaics. More precise methods of measurement were used in Naval Oil-Shale Reserve No. 2 and in establishment of a triangulation net for the mapped area. Because considerable error may have been introduced by measurement of distances from aerial mosaics (even though the use of vertical angles was kept to a minimum) the structure-contour map-except for that part in the reserve-is classed as reconnaissance.

The geologic map was compiled on a mosaic of parts of three Army Map Service quadrangle maps $\left(1^{\circ} \times 2^{\circ}\right)$.

\section{GEOGRAPHY \\ TOPOGRAPHY}

Most of the mapped area is on a north-sloping highly dissected plateau, the surface of which generally conforms to gentle dip slopes. Along the northeast side of the area the strata dip more steeply than on the plateau surface and form cuestas and hogbacks. The south edge of the plateau is delineated by the southfacing Roan Cliffs, a prominent topographic feature of eastern Utah and western Colorado formed on exposures of the lower part of the Green River Formation and of the upper part of the Wasatch Formation.

The numerous stream valleys, which dissect the plateau, are narrow and steep-walled and commonly have a relief of several hundred feet. The Green River, which forms much of the western boundary of the mapped area, has cut a canyon that has a maximum relief of about 4,000 feet. Interstream divides between major drainages are broad and generally have benchlike or mesalike shapes that give form to the plateau. These divides trend north and thus facilitate travel in a north-south direction. Rugged canyon walls hinder east-west travel.

The maximum altitude, about 9,500 feet, is on the southernmost part of the plateau, and the minimum altitude, about 4,300 feet, is along the Green River approximately 18 miles northwest of the highest area.

\section{ACCESSIBILITY}

Principal access to the eastern part of the area is Utah State Highway 45, which intersects U.S. Highway 40 about 24 miles east of Vernal, Utah, and extends southeastward to the Colorado-Utah border. State Highway 45 is paved from U.S. Highway 40 southward to Bonanza; the rest is unpaved. Access to the western part of the area is afforded by a secondary road that extends south from Ouray, Utah, to the edge of the plateau. In the mapped area this road and State Highway 45 are connected by only one good secondary road. The small part of the area west of the Green River is accessible by fair to poor secondary roads that roughly parallel Minnie Maud Creek. Although the numerous secondary roads are of fair to good quality, much of the area is accessible only on horseback or on foot.

\section{POPULATION AND INDUSTRY}

The estimated population of the mapped area is 225250 persons, which indicates a density of 1 person for each 10 square miles. About 200 people live in Bonanza, the only settlement, and the rest live on ranches in valleys drained by perennial streams. The nowabandoned mine camps of Dragon, Rainbow, and Watson were inhabited when gilsonite was mined nearby. Rainbow, the last to be abandoned, was intermittently inhabited until about 1952.

Much of the population is employed by the American Gilsonite Co. at Bonanza. The rest of the population is occupied mainly by stockraising and farming. Stockraising is the more prevalent because of low rainfall and the very small amount of irrigable land.

\section{DRAINAGE AND WATER SUPPLY}

The Green River, the master drainage of the Uinta Basin, heads in west-central Wyoming and flows southward to its confluence with the Colorado River, about 60 miles south of the mapped area. The Green River and its tributaries drain the entire basin. The White River, which is second in size to the Green River, heads in northwestern Colorado and flows westward to its confluence with the Green River, near Ouray, Utah. During wet climatic cycles the major creeks, such as Bitter, Willow, and Hill Creeks are perennial. During dry cycles, parts of these streams become intermittent. In general, water in these streams is suitable for drinking where the streams are above an altitude of 6,500 feet. Along the lower courses, however, the water is alkaline, and much of it is not potable. No observations were made of the streams that drain southward into the Colorado River.

Most of the springs occur in the southern part of the area at altitudes above 6,000 feet; in the southwestern part the principal aquifer is the Horse Bench Sandstone Bed of the Green River Formation or from adjacent sandstone beds. Commonly, the sandstone beds in the Douglas Creek Member of the Green River Formation and in the Renegade Tongue of the Wasatch Formation are the aquifers for springs in the southeastern part of the area. 


\section{VEGETATION}

The most common shrubs in the area are sagebrush, rabbitbrush, greasewood, and serviceberry. The trees are cottonwood, willow, aspen, juniper, piñon, and fir.

The area can be roughly divided into three zones, according to the predominant vegetation as follows:

1. A zone 4,500-6,000 feet in altitude that supports mostly sagebrush, rabbitbrush, and greasewood and has cottonwood and willow along the perennial streams.

2. A zone 6,000-7,500 feet in altitude that contains mostly juniper, piñon, and sagebrush.

3. A zone 7,500-9,500 feet in altitude that supports mostly fir, aspen, serviceberry, and sagebrush.

The flora of the Uinta Basin was described in detail by Graham (1937).

\section{STRATIGRAPHY UNEXPOSED ROCKS}

Rocks of pre-Tertiary age are not exposed in the area, but rocks ranging in age from Precambrian to Cretaceous lie in the subsurface and are exposed a short distance north of the area. Kinney (1955) presented detailed stratigraphic sections and showed a general section of rocks exposed along the south flank of the Uinta Mountains near Vernal. His general section $(1955, \mathrm{pl} .6)$ has been updated as follows:

\begin{tabular}{|c|c|c|c|}
\hline System & Unit & $\underset{\text { (feet) }}{\text { Thickness }}$ & Dominant lithology \\
\hline \multirow{3}{*}{ Cretacoous } & Mesaverde Formation & 1,100 & Sandstone and shale. \\
\hline & Mancos Shale & $5,070-5,290$ & $\begin{array}{l}\text { Shale, siltstone, and } \\
\text { sandstone. }\end{array}$ \\
\hline & Dakota Sandstone & $85-135$ & Sandstone and shale. \\
\hline \multirow{4}{*}{ Jurassic } & Morrison Formation & $830-930$ & $\begin{array}{l}\text { Sandstone, mudstone, } \\
\text { and shale. }\end{array}$ \\
\hline & Curtis Formation & $150-270$ & $\begin{array}{l}\text { Sandstone, shale, and } \\
\text { limestone. }\end{array}$ \\
\hline & Entrada Sandstone & $105-215$ & Sandstone. \\
\hline & Carmel Formation & $125-390$ & Shale and sandstone. \\
\hline $\begin{array}{l}\text { Jurassic and } \\
\text { Triasslc }\end{array}$ & $\begin{array}{l}\text { Glon Canyon Sand- } \\
\text { stono }\end{array}$ & $720-1,030$ & Sandstone. \\
\hline \multirow{2}{*}{ Trinssic } & Chinlo Formation & $230-355$ & $\begin{array}{l}\text { Shale, sandstone, and } \\
\text { conglomerate. }\end{array}$ \\
\hline & Mocnkopi Formation & $820-1,120$ & Sandstone and siltstone. \\
\hline Permian & Park City Formation & $70-195$ & Limestone and shale. \\
\hline $\begin{array}{l}\text { Permian and } \\
\text { Ponnsylvanian }\end{array}$ & Weber Sandstone & $1,015-1,275$ & Sandstone. \\
\hline Pennsylvanian & Morgan Formation & $1,035-1,450$ & Limestone and sandstone. \\
\hline \multirow{2}{*}{ Mississipplan } & Black shale unit & $0-265$ & Shale and sandstone. \\
\hline & Limestone unit & $965-1,220$ & Limestone. \\
\hline Cambrian & Lodore Formation & $G-155$ & Sandstone. \\
\hline Precambrian & Uinta Mountain Group & $3,000-4,000$ & Shale and sandstone. \\
\hline
\end{tabular}

If maximum thicknesses of the units just described are totaled, the entire section is more than 19,000 feet thick. The formations in the lower part of this rock sequence thin and pinch out southward toward the Uncompahgre Uplift owing to truncation and nondeposition. Because of their great depth, these pinchouts have not been delineated by drilling. In the mapped area the Carter Oil Co. Minton-State 1 well, center of the NE1/4 SE $1 / 4$ sec. 32, T. 14 S., R. 20 E., penetrated about 8,100 feet of pre-Tertiary sedimentary rocks in which the Triassic beds rest on Precambrian granite (Miller, 1956).

\section{TERTIARY SYSTEM}

All bedrock exposed in the mapped area is of fluvial and lacustrine origin, and almost all is of Eocene age. The only exception is the Duchesne River Formation of Eocene or Oligocene age, which underlies less than 1 square mile in the northernmost part.

During much of Eocene time a large lake was present in the area now occupied by the Piceance Creek basin and the Uinta Basin in Colorado and Utah. Bradley $(1930$, p. 88$)$ proposed the name Lake Uinta for this former body of water. The size and position of the lake varied greatly, and during its earliest and latest stages it was probably divided into two or more parts. Lacustrine marlstone, oil shale, limestone, siltstone, and sandstone of the Green River Formation were deposited in Lake Uinta. During the period of expansion of Lake Uinta, fluvial beds were deposited that are now beneath and peripheral to the lake deposits. These fluvial deposits became the shale, sandstone, and conglomerate beds of the Wasatch Formation. During the waning period of the lake, fluvial beds were deposited peripheral to it and, when the lake dried up, finally blanketed the area. These beds are assigned to the Uinta Formation. The relation of Wasatch, Green River, and Uinta Formations in the mapped area is shown on plate 2, and the measured stratigraphic sections of these formations are graphically shown on plate 3 . In the mapped area the Duchesne River Formation, composed of red and gray fluvial sandstone and shale, may lie unconformably on the Uinta and Green River Formations. The relationship is not clear, however, due to poor exposures. In the central part of the Uinta Basin, however, the Duchesne River Formation occurs in contact with only the Uinta Formation and is conformable with it.

\section{WASATCH FORMATION}

The name Wasatch was first applied by Hayden $(1869$, p. 191) to a sequence of variegated sand, clay, and conglomerate exposed on the east side of the Wasatch Mountains. The Wasatch Formation (Eocene) in the mapped area is composed predominantly of red and gray shale and siltstone, and massive, irregularly bedded fine- to medium-grained gray to brown sand- 
stone containing a few thin lenticular conglomerates. The sandstones are predominantly quartz but contain some feldspar and other minerals. Individually, most Wasatch strata are irregular and discontinuous, but some zones of sandstone or shale within the formation can be traced for several miles. The formation is exposed around the east, south, and west edges of the area and in the upper reaches of the deep canyons. The sandstones weather to buff, brown, and reddish-brown ledges, and the shales weather to steep red and gray slopes. Only the upper part of the Wasatch was studied in detail, and the thickness of the entire formation was measured at only one locality-near Florence Creek.

The Wasatch Formation, in general, thickens westward from the Douglas Creek arch toward the Uinta Basin and eastward from the arch toward the Piceance Creek basin. According to G. H. Horn, U.S. Geological Survey (oral commun., 1961), the red beds and basal conglomerate, which are characteristic of the Wasatch Formation in much of the area near the south end of the Douglas Creek arch, are absent in the northeastern part of T. 4 S., R. 101 W., Colo. (just east of mapped area), and in this area an oolitic limestone unit of the Green River Formation rests on massive sandstone. The Wasatch Formation is more than 4,100 feet thick in the west-central part of the Uinta Basin (Abbott, 1957, enclosure 3) and is 5,500 feet thick in the eastern part of the Piceance Creek basin .(Donnell, 1961, p. 846). The thickness of Wasatch ranges from about 700 feet in wells in the northeastern part of the mapped area to about 3,000 feet on the outcrop near Florence Creek in the southwestern part.

In the area of this report the Wasatch Formation is divided into two major units: the main body of the Wasatch and the overlying Renegade Tongue (new name). Both units intertongue with the Douglas Creek Member of the Green River Formation.

\section{Main body of formation}

The upper part of the main body of the Wasatch Formation is composed of massive, irregularly bedded fineto medium-grained buff, gray, and brown sandstone, red and gray shale and siltstone, and some thin beds of conglomerate. The lower part was not studied in this investigation. The upper part of the Wasatch weathers to buff and reddish-brown ledges and steep variegated slopes. The main body of the Wasatch Formation crops out along the eastern, southern, and southwestern margins of the mapped area and in a structurally high area along Rat Hole Canyon in T. 14 S., R. 25 E., Utah.

In Desolation Canyon the upper part of the main body of the Wasatch intertongues with nearshore-lacustrine beds of the Douglas Creek Member of the Green
River Formation. This part of the Wasatch is designated as tongues $Z$ and $Y$ and has the same lithology as the main body elsewhere. Tongue $Z$ is 270 feet thick and tongue Y 110 feet thick near the junction of Wild Horse Canyon and the Green River. Throughout the mapped area the main body of the Wasatch is conformably overlain by tongue D of the Douglas Creek Member of the Green River Formation.

\section{Renegade Tongue}

The name Renegade Tongue is herein given to the sequence of massive, irregularly bedded brown and gray sandstones and red and gray shales and siltstones that constitute the upper part of the Wasatch Formation and intertongue with the Douglas Creek Member of the Green River Formation. The type section is on a ridge just north of Renegade Canyon, from which the name was derived, in T. 19 S., R. 20 E. (pl. 3, section E.) Renegade Canyon, a tributary of Thompson Canyon, is just south of the mapped area. The Renegade Tongue is 1,000 feet thick at the type locality and thins to the north and northeast owing to its intertonguing relation with the Douglas Creek Member of the Green River Formation. Northeast of a line projected approximately parallel to Tenmile Canyon (T. 16 S., R. $21 \mathrm{E}$.), the Renegade Tongue is divided into units $\mathrm{X}$ and $W$, which are separated by the lacustrine beds of the Green River Formation. Unit X, a predominantly red and gray shale, can be traced beyond the northeast edge of the area. The minimum measured thickness of unit $\mathbf{X}$ is 7 feet, at White River; north and southwest of this locality the unit thickens. Unit $W$, predominantly massive, poorly bedded sandstone, can be traced northeastward to the vicinity of Park Canyon (T. 11 S., R. 25 E.).

The Renegade Tongue conformably overlies Tongue D of the Douglas Creek Member of the Green River and is conformably overlain by tongue $\mathbf{A}$ of the Douglas Creek Member. The contact between the Renegade Tongue and the Douglas Creek Member separates gross lithologic units-predominantly fluvial Renegade Tongue from predominantly lacustrine Douglas Creek Member-but both units contain fluvial and lacustrine sediments.

\section{Source, environment, and age of the formation}

Most of the sediments which make up the upper part of the Wasatch Formation in the mapped area were derived from a region to the southwest and south. Wasatch beds composed of sediments derived from the Uinta Mountain region occur mainly outside the mapped area, although some occur in the northeastern part of the area.

The Wasatch Formation was deposited on flood plains and in streambeds and deltas near the edge of Lake 
Uinta. Little of the Wasatch sediments studied were deposited in a reducing environment, and the few coals or carbonaceous shales are very thin and extremely lenticular.

No diagnostic fossils were found in the Wasatch Formation, only fragments of vertebrate bones and plants. Tongues B and C of the Douglas Creek Member of the Green River Formation, which interfinger with the Renegade Tongue of the Wasatch, contain middle Eocene fossils. Thus, part (and perhaps all) of the Renegade Tongue is of middle Eocene age. That part of the main body of the Wasatch Formation exposed in the mapped area is assigned to early Eocene, as it is in most other areas. The lowermost part, exposed east and south of the mapped area, is probably Paleocene.

The Colton Formation is a fluvial sequence underlying the Green River Formation and is equivalent to all or part of the Wasatch Formation. It was named for exposures near Colton, Utah, in the western Uinta Basin (Spieker, 1946). The Colton Formation has not been mapped east of its type locality; thus, its exact relation to the Wasatch Formation of this report is not known.

\section{GREEN RIVER FORMATION}

The name Green River Shales (which was later changed to Green River Formation) was first used by Hayden $(1869$, p. 190) in describing excellent exposures along the Green River in Wyoming. The Green River Formation is composed of beds of oil shale, marlstone, shale, siltstone, sandstone, and oolitic, algal and ostracodal limestone and tuff deposited in a lacustrine environment. Thin, even, notably continuous beds (fig. 2) characterize the formation, particularly the marlstone, oil shale, siltstone, and tuff that were deposited in water

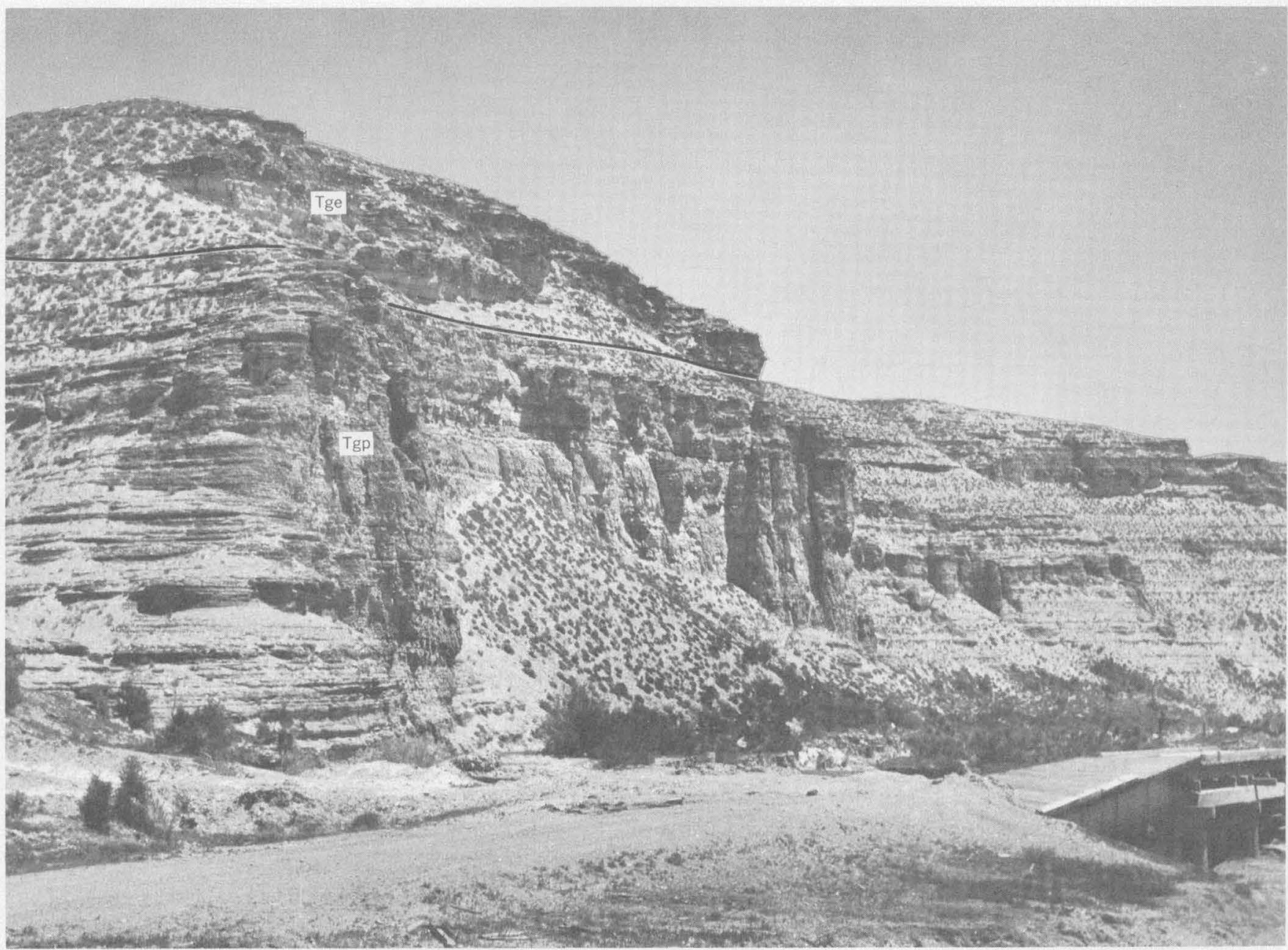

Figure 2.-Thin beds typical of much of the Green River Formation. Tge, Evacuation Creek Member; Tgp, Parachute Creek Member. View near Watson, Utah. 
GREEN RIVER FORMATION, UTAF AND COLORADO

deep enough to protect them from wave and current action. Some thin beds of sandstone and algal and oolitic limestone that were deposited in shallow water also display these characteristics; however, most of the shallow-water beds are more massive and are not laterally persistent. The lithology of the Green River Formation was first described in detail by Bradley (1931). Milton and Eugster (1959) described the mineral assemblages of the formation.

The Green River Formation is exposed in about 75 percent of the mapped area. It crops out everywhere except around the periphery of the mapped area and along some of the deep canyons. Thus, the Green River Formation controls the overall topography of the areaa north-sloping plateau that is highly dissected by steepwalled canyons.

Rocks of the Green River Formation described in this report are marginal to the area of maximum Green River deposition in the Uinta Basin, and the formation, as a whole, thickens toward a trough northwest of the mapped area. There are few localities where the entire thickness of the Green River can be measured in a small surface area, and total thicknesses obtained from composite sections are often suspect because of the abrupt lateral changes in thickness and lithology. The intertonguing of Green River and Wasatch Formations impedes the determination of cumulative thicknesses in exploratory wells, as well as impeding the selection of formation boundaries.

The maximum total thickness of the Green River Formation measured within a small surface area is about 1,900 feet at Raven Ridge (pl. 3, section O). The maximum total thickness obtained from partial sections (pl. 3, sections A, H) by extrapolation, excluding those intertonguing units of the Wasatch Formation, is at least 2,100 feet. Exploratory well data indicate that the total cumulative thickness in the northwestern part of the area is 2,500-3,000 feet. Outside the mapped area the thickness of the Green River Formation, including the Green River-Uinta transition zone, is more than 7,000 feet near Duchesne, Utah (Abbott, 1957, enclosure 4).

The Green River Formation can be visualized as a jagged-edged lens of lacustrine strata enveloped in a shell of fluvial strata. The upper part of the formation interfingers with fluvial beds of the Uinta Formation, and the lower part interfingers with fluvial beds of the Wasatch Formation. During part of geologic time the Uinta and Wasatch Formations probably formed a continuous fluvial sequence in the area peripheral to Lake Uinta. If such a continuous sequence existed, however, it has since been removed by erosion or hidden by younger Tertiary strata.
Intertonguing of the Green River and the Wasatch Formations is complex, and in many localities the contacts between shallow-water lacustrine rocks of the Green River Formation and fluvial rocks of the Wasatch are subtle and difficult to determine. Selection of contacts was therefore an attempt to delineate the rock sequences of predominantly shallow-water lacustrine origin from those of predominantly fluvial origin, but each tongue may contain both types of lithology. Intertonguing between the Green River and the Uinta Formations is less problematic, for the differences between these lacustrine and fluvial rocks are more obvious (fig. 3).

The major source area for most detrital sediments in the Green River Formation in the mapped area lay to the southwest and is denoted by the increase southwestward in grain size and in number of sandstone beds. Part of the basin received a large amount of sediment from the Uinta Mountain area during Green River time; that part is north and northwest of the mapped area. A slight increase in thickness of the nearshore-lacustrine deposits toward the southern part of the Douglas Creek arch indicates that this area was topographically high during early Green River time; however, this area probably did not contribute a large amount of sediment to the Green River lake.

Member names applied by Bradley (1931) to the Green River Formation in the Piceance Creek basin and in the eastern Uinta Basin are used in this report, but the boundaries of some of these members have since been somewhat modified. The members of the Green River Formation are, in ascending order, the Douglas Creek, Garden Gulch, Parachute Creek, and Evacuation Creek Members.

Precise correlation of the Green River Formation in the Piceance Creek basin and in the Uinta Basin has been established through the use of key beds in the Parachute Creek Member. Correlation of the Green River Formation in the Uinta Basin with the Green River Formation of the Washakie and Green River basins of southwestern Wyoming is as yet uncertain.

\section{DOUGLAS CREEK MEMBER}

The Douglas Creek Member, named by Bradley (1931, p. 10), is composed mainly of sandstone, siltstone, shale, and oolitic, algal, and ostracodal limestones; locally it contains a few oil-shale beds. The sandstone beds are composed mostly of fine- to medium-grained quartz and weather to gray and brown ledges. They are predominantly even bedded, although some are crossbedded, and their upper surfaces are more planar than the upper surfaces of the sandstone beds assigned to the Wasatch Formation. In part of the area the upper sandstone beds of the Douglas Creek Member contain 


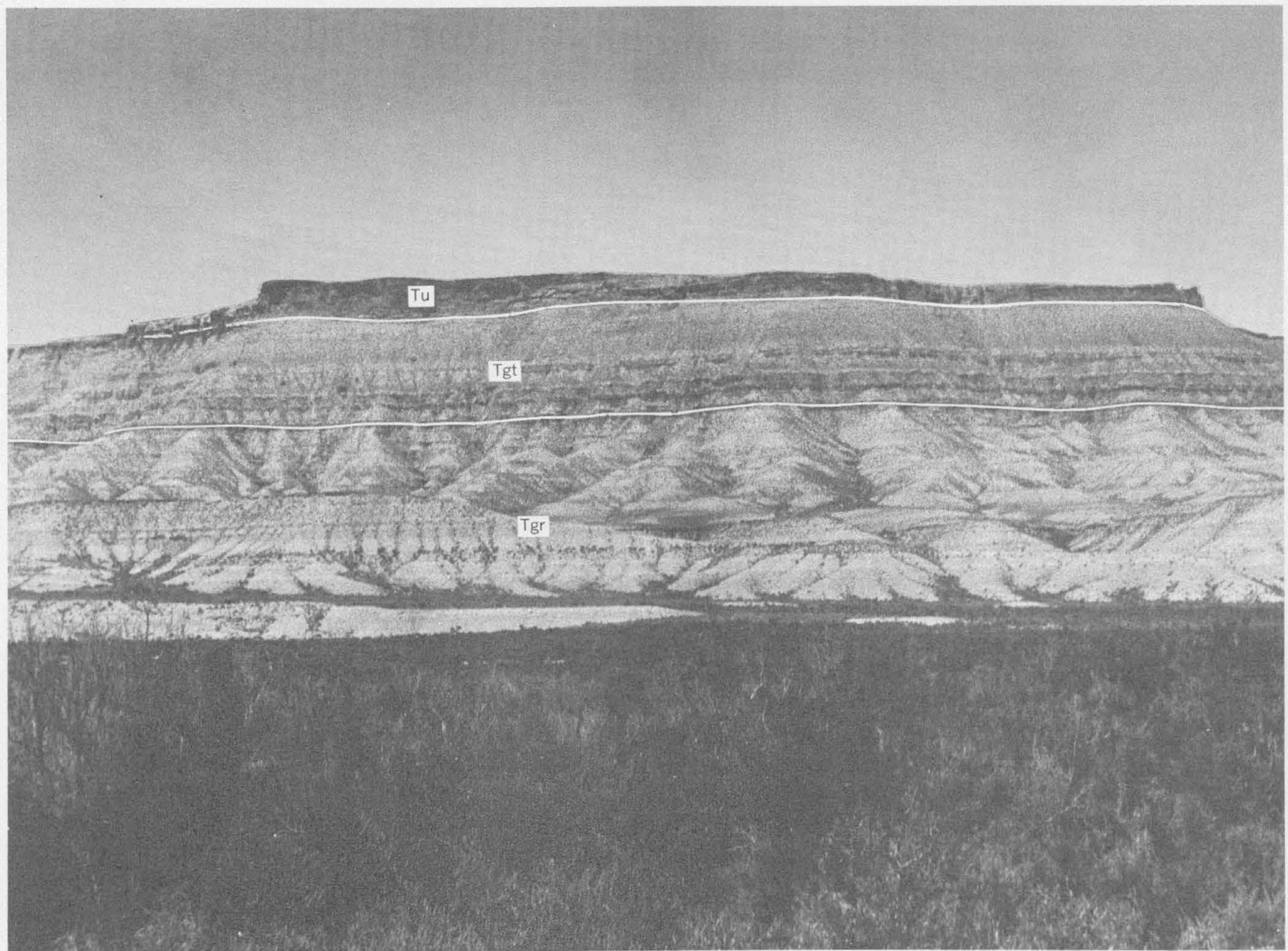

FIGURE 3.-Contact relation between the Green River Formation and the Uinta Formation, near Willow Creek in the northeastern part of T. 12 S., R. 20 E. Tu, Uinta Formation; Tgt, unmapped transition zone (included with the Green River Formation on pl. 1) ; and Tgr, Green River Formation.

appreciable amounts of bituminous material. These beds are described in section "Economic Geology" of this report. The siltstone is predominantly gray to tan and weathers to tan or reddish-brown ledges and steep slopes. The shale is gray, tan, and green and weathers to green or gray slopes. Oolitic, algal, and ostracodal limestones of this unit are thin bedded to massive and are commonly gray. These limestones weather to distinct orange-brown ledges on many outcrops. Oil-shale beds of the Douglas Creek Member are thin and are less widespread than those of the Parachute Creek Member and-except for the uppermost oil-shale beds in the northwestern part of the area-have little economic significance.

Principal outcrops of the Douglas Creek Member occur along the walls of deep canyons and along the Roan Cliff's. This member is characterized by a rugged topography, displaying many cliffs and ledges dissected by numerous gullies.

The Douglas Creek Member is probably thickest along a west-northwest-trending strip that is several miles wide and extends from the northwest corner of the area to the northeast corner of T. 13 S., R. 25 E. Northeast of this strip the member grades into and interfingers with the Parachute Creek and Garden Gulch Members, and southwest of this strip it grades into and interfingers with the Wasatch Formation. The Douglas Creek Member is about 1,060 feet thick at Raven Ridge, T. 2 N., R. 104 W., and about 870 feet thick at Hells Hole Canyon, T. 10 S., R. 25 E., indicating that the Raven Ridge area lay on the northern edge of the lake. The maximum measured thickness of the member, exclusive of intertonguing units, is 1,180 feet, along Evacuation Creek in Tps. 11 and 12 S., R. 25 E. The thick- 
ness is probably greater, however, in the northwestern part of the area, where the basal part of the member is not exposed. The Douglas Creek may be at least 2,000 feet thick in the subsurface beneath T. 11 S., R. $19 \mathrm{E}$. The member is thinnest in the southern part of the area. A cumulative thickness of 220 feet was measured in Renegade Canyon (pl. 3, section E).

The Douglas Creek Member grades laterally into and intertongues with the Parachute Creek and Garden Gulch Members of the Green River Formation in a basinward direction. Douglas Creek sandstone grades laterally into siltstone, which in turn grades laterally into marlstone; and Douglas Creek limestone intertongues with marlstone and oil shale of the Parachute Creek and Garden Gulch Members. Sandstone, siltstone, and algal and oolitic limestone in the Douglas Creek Member occur close to the Mahogany oil-shale bed in the southern part of the area (fig. $4 B$ ), but near the White River the uppermost beds of these lithologies are separated from the Mahogany oil-shale bed by 450 feet of Garden Gulch and Parachute Creek strata (fig. $4 A$ ). This separation is the result of contemporaneous deposition of the shallow-water lacustrine Douglas Creek sediments near the edge of Lake Uinta and the deep-water lacustrine Garden Gulch and Parachute Creek sediments along the trough of the lake, which trended west near the present course of the White River.

The Douglas Creek Member also grades laterally into, and intertongues with, the Wasatch Formation in a shoreward direction. Evenly bedded sandstone of the Douglas Creek Member grades laterally into irregularly bedded coarser grained sandstone of the Wasatch, and the algal and oolitic limestone and other shallow-water lacustrine strata intertongue with sandstone and shale of the Wasatch.

Many thin nearshore-lacustrine units extend laterally from the main part of the Douglas Creek Member. Only six units, containing most of the nearshoredeposited beds, were considered to be tongues of the Douglas Creek Member. Other tongues are present but are too thin to be recognized consistently or mapped separately.

\section{Tongues of member}

In the mapped area six lacustrine tongues of the Douglas Creek Member, designated in descending order as tongues $\mathbf{A}$ through $\mathbf{F}$, have been differentiated from the intercalated Wasatch strata. Lithologic composition of these tongues is virtually the same as that of the main part of the Douglas Creek Member. Tongue B was mapped with unit $W$ of the Renegade Tongue of the Wasatch Formation, however, and tongue $\mathrm{D}$ was mapped with the basal part of the Renegade Tongue. All other tongues are shown individually on plate 1 .
Tongues $\mathrm{F}$ and $\mathrm{E}$ of the Douglas Creek Member interfinger with the main body of the Wasatch Formation and crop out only along the Green River. The southeastern and eastern limits are not known. These tongues contain many beds that are characteristic of nearshore-lacustrine deposition; also, they contain a larger proportion of beds associated with fluvial deposition than the other tongues of the Douglas Creek Member. This sequence, deposited during times of lake-level fluctuation, is difficult to subdivide. The algal and oolitic limestones and the relatively even bedding in tongues $\mathrm{F}$ and $\mathrm{E}$ relate these tongues more closely to the Douglas Creek Member than to the main body of the Wasatch Formation. In Wild Horse Canyon, tongue $\mathrm{F}$ is 85 feet thick and tongue $\mathrm{E}$ is 230 feet thick; they are separated by 270 feet of the Wasatch Formation (pl. 3, section B). Tongues F and E may be shoreward equivalents of the upper part of the "black shale facies" of Picard (1955, p. 83-87).

The "black shale facies" is a dominantly lacustrine unit that presumably is confined to the subsurface of the Uinta Basin. It is characterized by dark-gray or black thinly laminated shale and has a maximum thickness of approximately 1,100 feet in an exploratory well near Duchesne, Utah (Picard, 1955, p. 84).

Tongue D of the Douglas Creek Member crops out in the mapped area as a thin band around the eastern, southern, and southwestern margins of the basin. It is composed mostly of shale and algal and oolitic limestone and crops out as a series of orange-brown ledges and gray slopes. Measured thickness of the tongue ranges from 6 feet in the Renegade Canyon section in the southern part of the area to 150 feet in the Evacuation Creek section in the northeastern part. Tongue $D$ is less than 50 feet thick throughout much of the area and was therefore mapped with the Renegade Tongue of the Wasatch Formation. In the northeast half of the area, it was mapped with the overlying unit $\mathrm{X}$ of the Renegade Tongue, and in the southwest half, with the undivided Renegade Tongue. Tongue $\mathrm{D}$ probably underlies the entire mapped area.

Tongue $\mathrm{C}$ of the Douglas Creek is composed of gray and green shale and siltstone, gray and brown algal, oolitic, and ostracodal limestone, and gray and brown sandstone, as well as a few thin beds of dark-gray and brown oil shale and marlstone. The tongue crops out in a narrow band extending along the eastern and southeastern margins of the area. Tongue $\mathrm{C}$ weathers to green, gray, and brown ledges and steep slopes. Measured thickness of tongue $\mathrm{C}$ ranges from 200 feet at Hay Canyon to 560 feet on Evacuation Creek (pl. 3, sections $\mathrm{F}, \mathrm{L})$. Tongue $\mathrm{C}$ presumably pinches out to the southwest along a northwest-trending line projected from the 


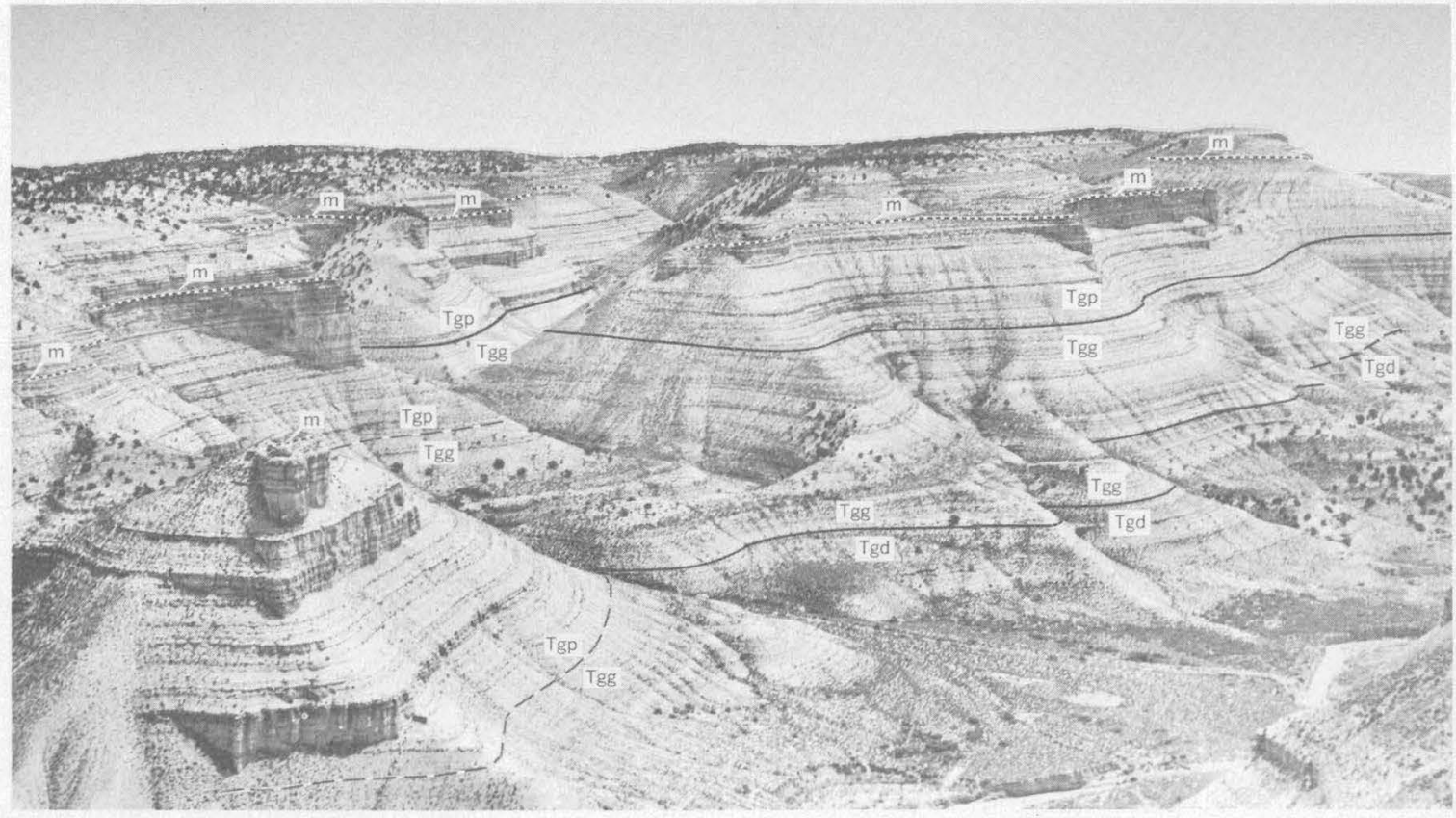

A

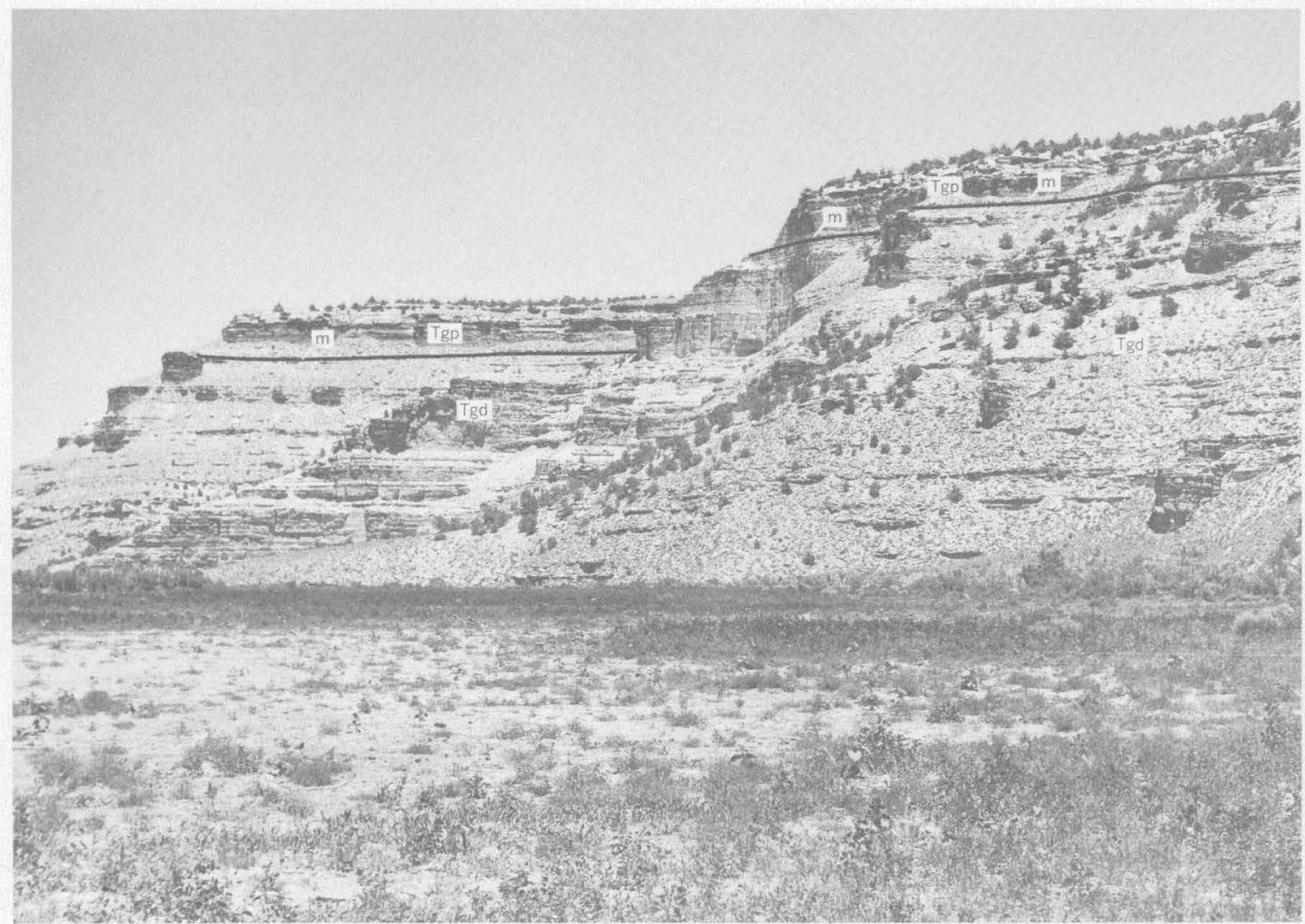

$B$

Figure 4.-Members of the Green Member Formation, as viewed $(A)$ east across Hells Hole Canyon from sec. 17, T. 10 S., R. 25 E., and $(B)$ north along Hill Creek, sec. 1, T. 14 S., R. 19 E., Uintah County, Utah. Tgp, Parachute Creek Member, including the Mahogany oil-shale bed, m, Tgg, Garden Gulch Member; and Tgd, Douglas Creek Member. 
middle of T. 17 S., R. 22 E., to the northwest corner of T. 11 S., R. $19 \mathrm{E}$; it is underlain by unit X of the Renegade Tongue and is overlain by unit $\mathrm{W}$ of the Renegade Tongue.

Tongue B of the Douglas Creek is composed of gray and green siltstone and shale, gray and brown sandstone, and gray and brown algal, oolitic, and ostracodal limestone. This tongue crops out in the deeply incised parts of Hill Creek, Willow Creek, and Main Canyons, and along the southeastern margin of the mapped area. It forms a thin series of ledges and steep slopes and is both overlain and underlain by the massive fluvial sandstones of unit $W$ of the Renegade Tongue, with which it is mapped. Tongue B is 70-95 feet thick. It pinches out to the south and southwest and probably merges with the basal part of tongue $A$ in the subsurface in the northwestern part of the mapped area.

Tongue $\mathbf{A}$ is composed of gray and green siltstone and shale, gray and brown sandstone, and gray and brown algal, oolitic, and ostracodal limestone, as well as a few thin beds of dark-gray and brown oil shale and marlstone. This tongue contains almost all the oil-shale beds of the Douglas Creek Member, but these beds are much less extensive than those of the Parachute Creek Member. Most oil-shale beds of the tongue occur in its upper 50 feet in an area bounded on the northeast by a line projected parallel to Main Canyon and on the south by the Uintah County line. Tongue $A$ crops out throughout much of the area, either in broad strips, as in the southeast, or in narrow bands, as in the west. Outcrops of this tongue commonly weather to gray, reddish-brown, and green ledges and steep slopes. Much of the limestone weathers a distinctive orangebrown. Measured thickness of tongue A ranges from 210 feet in the Renegade Canyon section to 455 feet in Evacuation Creek (pl. 3). Tongue A conformably overlies and interfingers with unit $W$ of the Renegade Tongue of the Wasatch Formation and in much of the area is conformably overlain by, and interfingers with, the Parachute Creek Member of the Green River Formation. South of White River and east of Evacuation Creek, however, tongue $\mathbf{A}$ is overlain by, and interfingers with, the Garden Gulch Member; southwest of Main Canyon it is overlain by the Mahogany oil-shale bed.

Source, environment, and fossils

The source area for most sediments of the Douglas Creek Member was south and southwest of the mapped area. In the northeastern part of the area, however, the member contains sediments derived from a source north or northeast of the mapped area. The presence of thick algal and oolitic limestone beds in tongue A of the Douglas Creek Member in the southeastern part of the area indicates that much of the region now occupied by the southern part of the Douglas Creek arch was topographically high during part of Douglas Creek time but was not subjected to subaerial erosion.

Beds of the Douglas Creek Member were deposited near the lakeshore in shallow water that had an abundant supply of lime. This conclusion is substantiated by the presence of ripple marks, mudcracks, and crossbedding, and the numerous beds of oolitic and algal limestone. Bradley (1929, p. 223) stated that probably most of (and certainly some of) the algal reefs were formed in water less than 6 feet deep, although a few may have formed in water as much as 15 feet or more deep. The lower part of the Douglas Creek Member was deposited during a period of rapid water-level fluctuation in Lake Uinta. The upper part of the member was laid down during a phase in which the lake was predominantly transgressive.

Fossils found in the Douglas Creek Member include mollusks, ostracodes, turtle and fish bones, and gar-pike scales. The mollusks, identified by John B. Reeside, Jr., are Australorbis spectabilis Meek, Australorbis sp., Lymnae? sp., Physa bridgerensis Meek, Physa pleromatis White, Physa sp., and "Planorbis" sp. in tongues $\mathrm{B}$ and $\mathrm{C}$ of the Douglas Creek Member along the Roan Cliffs. An age determination more restrictive than middle Eocene cannot be given to these forms. Swain (1956) described several ostracode zones of the lower part of the Green River Formation, but he designated the age only as early Tertiary. Bones and scales found in the report area were too fragmentary to be useful in age determinations.

\section{GARDEN GULCH MEMBER}

The Garden Gulch Member was named by Bradley (1931, p. 10) for exposures along Garden Gulch, in the Piceance Creek basin. In the report area the member is composed chiefly of marlstone containing appreciable amounts of organic matter, oil shale, and siltstone. The Garden Gulch Member is characterized by thin- and even-bedded gray and brown marlstone and contains less oil shale than the overlying Parachute Creek Member. Most beds are less than 1 inch thick, and some outcrops contain layers which are paper thin. The member forms steep slopes that are broken by small ledges of resistant oil-shale beds.

The outcrop of the Garden Gulch in the mapped area is restricted to a narrow strip of land south of the White River and east of Evacuation Creek. Northeast and southwest of the strip, the member is absent because of gradation into the Douglas Creek and Parachute Creek Members. Oil-yield assays of rotary cuttings from exploratory wells west of the Garden Gulch outcrop indicate that the oil-shale sequence below the 
Mahogany bed assigned to the Parachute Creek Member is thicker in the subsurface than on the outcrop. Thus, the upper part of the Garden Gulch Member probably grades laterally westward into the lower part of the oil-shale-bearing Parachute Creek Member. Maximum measured thickness of the Garden Gulch Member is 230 feet, in Hells Hole Canyon; to the northeast and southwest, the member thins.

The gray slope-forming beds of the Garden Gulch Member are markedly different from the underlying brown ledge-forming beds of the Douglas Creek Member. The upper part of the Garden Gulch and the lower part of the Parachute Creek members are lithologically similar, however, and the two members can be distinguished mainly by the larger number of oil-shale beds in the Parachute Creek (Bradley, 1931, p. 11). The Parachute Creek Member is predominantly a cliffforming unit in that part of the basin where the Garden Gulch Member is exposed. Topographic break between these two member's, however, does not occur at the same horizon everywhere and is not significant enough to be used in making a precise correlation. Oil-shale beds in the lower part of the Parachute Creek are lower grade and less abundant than oil-shale beds in the middle part and the choice of a contact between the Garden Gulch and Parachute Creek members is rather arbitrary. At some localities the two could be considered as one unit. If the reader compares the contacts of the Garden Gulch Member as shown by Cashion and Brown (1956, fig. 1) and the contacts of the Garden Gulch Member as shown in this report (pl. 3), he will find that these contacts have been changed. In reexamining the White River and Hells Hole stratigraphic sections, the author found that the contacts shown in the carlier report did not correspond to those originally designated by Bradley. The contacts have been changed to conform more closely to those of Bradley, even though the author believes that the Garden Gulch Member in the mapped area is the lateral equivalent of the lower part of the Parachute Creek Member in the Piceance Creek basin.

source, environment, and fossils

The Garden Gulch Member was deposited along the trough of Lake Uinta in water that was probably less than 75 feet deep. The member contains only a small amount of coarse sediment and consists mostly of lime, clay, and organic matter.

Fossils found in the Garden Gulch Member consist of fly larvae, ostracodes, fish scales, and plant fragments. No age assignment can be made on the basis of these fossils.

$236-4860-60-3$

\section{PARACHUTE CREEK MEMBER}

The Parachute Creek Member, named by Bradley (1931, p. 11) for exposures near Parachute Creek in the Piceance Creek basin, is composed mainly of marlstone, oil shale, siltstone, sandstone, and tuff. It contains the principal kerogen-rich beds in the Green River Formation. Lithologic units of the Parachute Creek Member are predominantly thin and even bedded and are laterally continuous. Most strata are less than 1 inch thick, and some of the oil shales are paper thin. Key tuff beds less than 5 inches thick can be traced over thousands of square miles in the Piceance Creek basin and Uinta Basin.

The Parachute Creek Member in the northeastern part of the mapped area is lithologically unlike that in in the southwestern part. Line $B-B^{\prime}$ (pl. 3, index map) is the approximate boundary between these two lithologies. In the northeastern part of the area, the Parachute Creek Member is composed mostly of thinbedded marlstone, oil shale, and tuff, all deposited in a deep-water lacustrine environment. This lithology is typical of the Parachute Creek Member. In the southwestern part of the area the member is composed mostly of siltstone and sandstone deposited in a shallowwater lacustrine environment, and it contains few beds of oil shale or tuff.

Oil shale has been defined in various ways (Bradley, 1931, p. 7). In this report, however, the term "oil shale" is used for marlstone that will yield 15 gallons or more of oil per ton when subjected to destructive distillation. The physical and mineralogic characteristics of the oil shale in the Green River Formation were described in detail by Bradley (1931, p. 22-32). These oil-shale beds consist of magnesian marlstone having a high content of organic matter in the form of kerogen. Unweathered oil shale ranges from brown to very dark gray owing to differences in its kerogen content. Beds that contain the most kerogen are thus the darkest in color, as well as the most resistant to erosion. The beds having a high content of organic matter weather to distinctive blue-gray ledges. The bedding of weathered oil shale is thin to very thinly laminated, but it may appear massive in fresh exposures.

Beds containing the most kerogen crop out in a resistant dark-gray unit called the Mahogany ledge. In the mapped area it is 2-60 feet thick. This unit was so named by Bradley $(1931$, p. 23) because polished surfaces of the shale resemble old mahogany. Its subsurface correlative is called the Mahogany zone. The thick oil-shale bed containing the most kerogen-the Mahogany bed-occurs near the top of the Mahogany ledge. Other groups of kerogen-rich oil-shale beds that weather to dark-gray ledges occur above and below the 
Mahogany ledge but are not as thick nor as rich in kerogen content as the Mahogany ledge. Near the depositional axis of the lake in the mapped area, the Mahogany zone and the adjacent groups of kerogenrich beds just mentioned occur in a sequence about 400 feet thick that is made up predominantly of oil shale, as indicated by oil-yield assays of cores. The Mahogany oil-shale bed lies approximately in the middle of the 400 -foot-thick sequence. The thickness is estimated to be at least 700 feet in an area a few miles to the west. In general, all units of this sequence are thickest near the depositional axis of the basin and thinnest away from this axis, which trends approximately east near the confluence of the White River and Evacuation Creek. Thus the axis lies north of the western part of the mapped area. Position of the axis within the mapped area was relatively stable during Garden Gulch and early Parachute Creek time but may have shifted slightly southward during late Parachute Creek time. Near the depositional axis, the Mahogany ledge is about 60 feet thick and the Mahogany oil-shale bed is about 9 feet thick. Along the southern part of the Raven Ridge and in the area southwest of line $B-B^{\prime}$ (pl. 3, index map), however, the Mahogany ledge consists mainly of the Mahogany oil-shale bed, which is 2-5 feet thick in these areas. Variations in thickness and in kerogen content of the Mahogany bed and adjacent beds are shown on plate 4 .

The thick oil-shale sequence grades laterally into, or interfingers with, beds of marlstone and siltstone in any shoreward direction. In turn, the marlstone and siltstone grade into or interfinger with beds of siltstone and sandstone. Near Hells Hole Canyon the oil-shale sequence of the Parachute Creek Member extends downward 250 feet from the Mahogany oil-shale bed. Along Raven Ridge and southwest of Main Canyon, however, rocks below the Mahogany oil-shale bed contain few or no oil-shale beds, and much of the 250 -foot-thick interval immediately below the Mahogany oil-shale bed is occupied by sandstone of the Douglas Creek Member. Also, the Parachute Creek rocks above the Mahogany oil-shale bed contain fewer and thinner oil-shale beds in these two areas than at Hells Hole Canyon.

The marlstone and silty marlstone beds of the Parachute Creek Member are mostly thin bedded, although they may appear to be massive on a surface that has not been deeply weathered. Many of these marlstones contain organic material that imparts a brown hue to the unweathered surfaces. Units containing only small amounts of organic material are light gray or tan. Weathered marlstone and silty marlstone are gray to buff, are commonly fissile, and form ledges and steep slopes.

The siltstone is calcareous and commonly contains tuffaceous material and minor amounts of organic matter. Although beds of siltstone occur northeast of line $B-B^{\prime}$ (pl. 3, index map), they are much more common in the area southwest of this line.

Many tuff beds occur in the Parachute Creek Member in the area northeast of line $B-B^{\prime}$. They occur in a stratigraphic sequence that was deposited in lake water deep enough that the sediments were undisturbed by current or wave action. Southwest of line $B-B^{\prime}$ there are few tuff beds, and only one tuff (which is at the base of the Mahogany bed and is thin and undulating) has great areal extent. This paucity of tuff beds in the southwestern part of the area is seemingly due to wave or current action in shallow water. The ash that fell on the lake surface over shallow water was greatly diluted by other sediment while settling to the lake bottom and thus did not form distinctive layers.

Sandstone in the Parachute Creek Member is composed of quartz and a lesser amount of feldspar and contains such accessory minerals as biotite, muscovite, and zircon. The grain size is very fine to medium, and carbonate is the most common cementing material. The sandstone bedding is thin to massive, the massive beds being most prevalent in the southernmost part of the area. The sandstone is gray to brown and weathers to gray or brown ledges and cliffs.

The thickness and number of sandstone beds in the Parachute Creek Member increase from northeast to southwest. Along the Hill Creek anticline, and for about 10 miles north of it, one prominent resistant sandstone and siltstone sequence occurs between the Mahogany bed and the Horse Bench Sandstone Bed. This sequence, ranging in thickness from 10 to 50 feet, forms extensive mesa tops in many areas where the Horse Bench Sandstone Bed has been removed by erosion. It grades into siltstone to the north and northeast and in the southernmost part of the area is associated with several other ledge-forming sandstones.

Lenticular sandstones locally occur near the Mahogany oil-shale bed in the west-central part of the mapped area. These massive sandstone lenses range in width from a few tens of feet to a few hundred feet and are as much as 50 feet thick. Oil-shale and marlstone just below the main mass of each sandstone lens are commonly downwarped and thinned but do not seem to be eroded. Contorted bedding is evident in all of these lenses. At several localities a sequence of oil shale and marlstone 10-20 feet thick, which includes the Mahog- 
any oil-shale bed, overlaps itself for a distance of a few hundred feet, and a sandstone lens occurs between the overlapping parts. Evidence of faulting is not visible in this sequence, and the overlying and underlying strata are continuous. The author believes that plastic flowage within the sandstone lenses was the cause of these bedding irregularities. The sandstones are very tuffaceous, as are the sedimentary dikes in the Green River Formation, and conditions that produced the dikes could also have produced plastic flowage in the lenticular sandstone bodies. No explanation can be offered for the localized accumulation of these coarser sediments that are enclosed in finer grained sediments. The general character and stratigraphic position of the sandstones do not indicate deposition in channels or bars; however, to conclusively determine their origin, a detailed study of those deposits would have to be made.

Near the Colorado-Utah border the measured thickness of the Parachute Creek Member ranges from about 365 feet along Evacuation Creek to about 615 feet along the White River. Oil-yield assays show that the thickness of oil shale in the member increases westward along the depositional axis of the basin.

In most of the mapped area the Parachute Creek Member overlies and.interfingers with the Douglas Creek Member. East of Hells Hole Canyon and south of the White River, however, the Parachute Creek overlies and interfingers with the Garden Gulch, which pinches out to the northeast and southwest and is absent along Raven Ridge and southwest of Hells Hole Canyon. The Parachute Creek-Douglas Creek contact from Evacuation Creek southwestward to Main Canyon was arbitrarily placed at the top of the uppermost sandstone bed. However, coarse-grained beds in this sequence become stratigraphically higher from northeast to southwest; in the area southwest of Main Canyon, sandstones occur above the Mahogany oil-shale bed. The Parachute Creek-Douglas Creek contact in this area was mapped as the base of the Mahogany oil-shale bed instead of the top of the uppermost sandstone because, by definition (Bradley, 1931, p. 11), the Parachute Creek Member contains the principal oil-shale beds of the Green River Formation.

The Parachute Creek Member underlies the Evacuation Creek Member. The boundary between these two members was selected on the basis of its mappability throughout the entire area and differs somewhat in stratigraphic position from the boundary as originally determined by Bradley $(1931, \mathrm{pl} .8$ ) in the easternmost part of the Uinta Basin and more recently by Dane $(1954,1955)$ in an area west of the Green River. Bradley (1931) did not define this boundary, but he described the Parachute Creek Member as being distinguishable from other parts of the Green River Formation by its content of oil-shale beds. In a stratigraphic section measured by Bradley in Hells Hole Canyon (1931, pl. 8 , section D), the boundary between the Parachute Creek and Evacuation Creek Members was placed a few feet above the Mahogany oil-shale bed. Dane (1954, p. $413 ; 1955$, columnar section 4 ), in a section near the head of Avintaquin Canyon (west of the mapped area), placed the boundary at the top of the oil-shale facies, as measured by Bradley (1931, pl. 11). Near the Duchesne County-Uintah County line just west of the mapped area, Dane (1955, columnar section 11) placed the boundary 315 feet above the Mahogany oil-shale bed. In the area southwest of the Rainbow and Black Dragon gilsonite veins the boundary between the Parachute Creek Member and the overlying Evacuation Creek Member is placed at the base of the Horse Bench Sandstone Bed. The top of the Horse Bench Sandstone Bed was not mapped because the unit is less than 20 feet thick in much of the area. This bed characteristically forms a prominent buff or brown ledge among gray slopeforming marlstones. South of T. 16 S., however, this sandstone occurs with other sandstones of similar appearance, and the Parachute Creek-Evacuation Creek boundary is difficult to determine. In general the rocks between the Horse Bench Sandstone Bed and the Mahogany oil-shale bed thicken westward. These rocks are 300 feet thick on Asphalt Wash, in T. 12 S., R. 24 E.; 390 feet thick along Willow Creek in T. 12 S., R. 21 E.; 400 feet thick along Willow Creek in T. 16 S., R. 21 E.; and 490 feet thick just west of the mapped area, in T. 11 S., R. 17 E. (Dane, 1955, columnar section 11). The Horse Bench Sandstone Bed pinches out northeastward a short distance northeast of the Rainbow and Black Dragon gilstonite veins, and where it is absent, selection of the Parachute Creek-Evacuation Creek contact was made on the basis of a color change that occurs at about the same stratigraphic position as the Horse Bench Sandstone Bed. The beds above this contact are predominantly brown or buff; those below, predominantly gray.

\section{Key beds of the Parachute Creek Member}

The Mahogany bed is the most useful and most widespread key bed in the Green River Formation. Its dark-blue-gray weathering color and ledge-forming character make it a distinctive unit throughout much of the area. It crops out either as a darker horizontal rib in the dark-gray Mahogany ledge or, where it constitutes the entire ledge, in a light-gray or tan sequence of marlstone and siltstone. Where the Mahogany oilshale bed is thin and covered by considerable vegetation and soil, such as south of the Uinta County-Grand 
County line, identification of it is more difficult. Identification at some localities in this southern part of the area must be made after the measurement of stratigraphic sections rather than before as can be done in the northern area.

Throughout its known extent the Mahogany oil-shale bed can be regarded as a time plane owing to its stratigraphic relation to tuff beds. Because the bed represents a time plane and crops out over a large area, it was used as a datum for the structure-contour map on plate 1.

The Mahogany marker, the best-known tuff bed in the Green River Formation, is 9-20 feet above the Mahogany oil-shale bed. It is a gray fine-grained unit which weathers to orange-brown rectangular blocks. On many outcrops the marker has the physical appearance of a sandstone and is commonly saturated with oil. It has very planar upper and lower surfaces, but there are no bedding planes within the unit. Evidence of the postdepositional flowage that is characteristic of many tuff beds in the Green River Formation was noted in the Mahogany marker at only one localitythat in the central part of T. 10 S., R. 25 E.

The Mahogany marker is present in that part of the area northeast of line $C-C^{\prime}$ (pl. 3, index map). The thickness is $0.3-0.6$ foot, averaging about 0.4 foot thick. Uniformity of thickness and appearance over a very large area distinguish the marker. The Mahogany marker also occurs in a large area in the Piceance Creek basin of Colorado (Donnell, 1961, p. 856) and, though not yet recognized, may be present in parts of the Green River and Washakie basins of Wyoming.

A distinctive contorted tuff bed occurs below the Mahogany oil-shale bed in the area northeast of line $C-C^{\prime}$ and in a narrow strip just southwest of this line. It occurs 25-85 feet below the Mahogany oil-shale bed and, commonly, in a recess at or near the base of the Mahogany ledge. The tuff is gray where unweathered and gray to brown where weathered. The most outstanding compositional feature of the bed is the large amount of megascopic analcite crystals. Outstanding physical features of this unit are extremely undulatory upper and lower surfaces and contorted bedding. The undulatory nature of the contacts causes great differences in thickness within short distances. Thicknesses ranging from 1 inch to 18 inches within a horizontal distance of 20 feet have been noted. The contorted, undulatory character is typical of this tuff throughout its extent, which includes a large part of the Piceance Creek basin (Donnell, 1961, p. 856).

Another distinctive tuff bed is present 55-85 feet above the Mahogany marker in virtually the same area as the contorted tuff bed. This bed is distinctive be- cause in most localities it contains thin intercalated stringers of marlstone that accentuate the wavy bedding surfaces formed by plastic flowage or differential compaction. The tuff is light gray to tan and weathers to gray and orange-brown outcrops, which are commonly not well exposed because of their nonresistance to erosion. This tuff also occurs in the Piceance Creek basin (Donnell, 1961, p. 856).

\section{source, environment, and rossils}

The Parachute Creek Member is composed predominantly of fine-grained precipitate from the lake water and various amounts of organic matter. It also contains coarser sediment, most of which was derived from a southwestern or southern source or from ash falls. Some sediment deposited in the northern part of the mapped area was derived from the Uinta Mountain area. The Parachute Creek Member was deposited in very shallow to deep lakes. The shallow-water, or shoreward, facies is mainly in the southern part of the area. These predominantly fine-grained strata, despite their appreciable content of coarse-grained material, are even bedded and were probably laid down on a gently sloping surface in calm water. The deep-water deposits, in the northern part of the area, were laid down on a nearly flat surface, as shown by the great continuity and uniform thickness of some beds, and were seldom subjected to wave or current action. Chemical or thermal stratification of the lake water greatly affected this environment, especially in the deposition and diagenesis of the oil shales (Bradley, 1948, p. 644). Some oil-shale beds display brecciation and mudcracks, and some occur in stratigraphic proximity to beds of algal limestone. These features and this relation indicate that the oil-shale was deposited in water so shallow that the shale was sometimes exposed.

During much of Green River time, Lake Uinta was presumably a single body of water occupying the area now included in the Piceance Creek basin and Uinta Basin. During most of Parachute Creek time, conditions varied uniformly throughout much of the lake. This uniformity can be demonstrated by the correlation of kerogen-rich zones and lean zones of oil shale, as well as beds within these zones, over large areas.

Fossils found in the Parachute Creek Member consist of insects, insect larvae, plant fragments, and fish scales. These remains, which were found at many horizons in the fine-grained facies, were of no value for correlation or age designation.

\section{EVACUATION CREEK MEMBER}

The Evacuation Creek Member, uppermost member of the Green River Formation, was named by Bradley (1931, p. 14) for excellent exposures along Evacuation 
Creek in eastern Utah. The member crops out as a narrow band across the northern part of the area and caps the plateau in much of the western third of the area.

Rounded hills and steep slopes are the topographic features common to the Evacuation Creek Member. At many localities in the western part of the area, the member is represented by only its lowermost unit-the Horse Bench Sandstone Bed-which forms the resistant caps on numerous mesas.

The Evacuation Creek Member is composed chiefly of marlstone and siltstone but.also contains some sandstone, tuff, oil shale, and oolitic limestone. The marlstone and siltstone are gray and brown, thin bedded, and fissile; they weather light gray and brown. These finer grained beds make up most of the Evacuation Creek rocks in the northern part of the area, but many sandstone beds are intercalated with them in the southern part. Some marlstone beds in the northeastern part of the area contain appreciable amounts of organic matter, but the member has no thick oil-shale sequences.

In the northwestern part of the area, the upper 250 feet of the Evacuation Creek contains several beds of fine-grained sandstone. The rocks in this interval are transitional from Green River to Uinta lithology (fig. 3), but they are mostly lacustrine. Eastward these rocks intertongue with and grade into predominantly fluvial rocks of the lower part of the Uinta Formation.

Sandstone beds in the Evacuation Creek Member are composed chiefly of very fine to medium-grained quartz. The bedding is thin to massive, and some units are cross laminated and ripple marked. In the southern part of the area, grain size and thickness of bedding of the sandstones increase to the southwest. The sandstone beds are. gray and brown and weather to gray and brown ledges and steep slopes.

The Horse Bench Sandstone Bed is a resistant ledgeforming unit that occurs at the base of the Evacuation Creek Member throughout much of the mapped area (pl. 3). In the southwestern part of the area it is a fine- to medium-grained sandstone having a maximum thickness of about 50 feet. Grain size and thickness decrease northeastward, and northeast of Main Canyon the bed has a maximum thickness of about 5 feet and is siltstone rather than sandstone. The bed pinches out near Evacuation Creek. Northeast of line $B-B^{\prime}$ (pl. 3 ; index map) the Horse Bench Sandstone Bed is underlain and overlain by light-gray marlstone and siltstone sequences that are less resistant to erosion than the Horse Bench, which weathers to a prominent buff or brown ledge and caps many mesas and benches. Southwest of line $B-B^{\prime}$ the Horse Bench Bed is associated with other resistant sandstones and is not as topographically conspicuous.
The Evacuation Creek Member in the northern part of the mapped area contains many tuff beds, most of which are less than 6 inches thick, are fine grained, and have planar upper and lower surfaces. All the tuff beds contain some biotite, and a few contain enough biotite to be dark gray. In general, however, the tuff beds are light gray to tan and weather to minor reddish-brown ledges.

The thickest tuff bed in the mapped area occurs in the lower part of the Evacuation Creek Member. Exposures of this bed occur mainly within an area bounded on the north by the White River and on the west by Evacuation Creek. The bed is as much as 20 feet thick at several localities along Evacuation Creek; in general; it thins northward, eastward, and southward from this area. Westward, it is not exposed, and its thickness is: not known. The very irregular upper and lower surfaces of this bed, as well as inclusions of marlstone, contorted bedding, and orientation of mica flakes, are indications of plastic flowage. In sec. 18, T. 11 S., R. 25 E., Utah, at a locality first called to the attention of the author by H. D. Curry of the Shell Oil Co., several square feet of the underside of the tuff bed can be seen. There the surface is marked with minute ridges and grooves which were seemingly caused by the slippage of the tuff over the surface below it.

Where the Evacuation Creek Member crops out near the junction of Evacuation Creek and the White River, a zone of marlstone and siltstone containing many ellipsoidal cavities occurs in the basal part of the member. These cavities are the result of the leaching of a soluble mineral. Milton and Eugster (1959) stated that the mineral was nahcolite, which occurred as nodules. In some places the nahcolite has been replaced by calcite. The cavities are about 6-24 inches long in their greatest dimension and are in a stratigraphic zone that has a maximum thickness of approximately 50 feet. The zone is informally called the "bird's-nest zone" because its outcrop commonly has the appearance of a wall supporting many swallows' nests.

The measured thickness of the Evacuation Creek Member ranges from 135 feet at Evacuation Creek to 545 feet at Willow Creek. South of T. 14 S., the upper part of the Evacuation Creek Member has been removed by erosion, and a total thickness cannot be measured.

The Evacuation Creek Member is overlain by and: interfingers with the Uinta Formation. In much of the area northeast of Bitter Creek, the contact between these two units, though mainly at one stratigraphic horizon, is undulatory, as a result of contortion of the sandstone beds in the basal part of the Uinta Formation. Near Bitter Creek the contorted sandstone beds and some sandstone beds above them pinch out to the west. Here, 
also, stratigraphically higher beds of massive sandstone: rest with normal contact on marlstone which is the lateral equivalent of the contorted basal sandstone northeast of Evacuation Creek. Westward from Bitter Creek there is an abrupt lateral change from a predominance of sandy beds, which make up the basal part of the Uinta Formation northeast of Bitter Creek, to a predominance of marly beds, which are included in the Evacuation Creek Member. West of Willow Creek the upper part of the Evacuation Creek Member contains a transition zone (fig. 3 ) of interbedded marlstone, siltstone, and sandstone, and the upper boundary of the member is 500 feet stratigraphically higher than at Bitter Creek. The transition zone was not mapped separately.

Source, environment, and fossils

The Evacuation Creek Member in most of the mapped area was deposited by the precipitation of lime from lake water and by ash falls. In the southern part of the area, however, the member contains coarser grained sediment derived from a source area to the south or southwest.

Most strata of the Evacuation Creek Member were deposited in quiet water that was seemingly deeper than the water in which the Douglas Creek Member was deposited and shallower than that in which the Parachute Creek Member was deposited.

During deposition of the Evacuation Creek Member, Lake Uinta was decreasing in size, and at the end of Evacuation Creek time the lake ceased to exist; the area was then blanketed by fluvial sediments. The lake retreated northwestward from the area, so that lacustrine deposition continued much later in the northwestern part of the area than in the northeastern part.

Lake Uinta evidently was not characterized by long periods of extreme desiccation, as was the lake that lay north of the Uinta Mountains. The lake deposits of the Green River Basin in Wyoming contain thick beds of saline minerals intercalated with nonsaline beds, whereas lake deposits in the mapped area contain saline minerals only as nodules or small crystals. The deepest part of Lake Uinta, however, lay outside the mapped area, and the sediments deposited there are now deeply buried and possibly contain beds of saline minerals.

Numerous beds of algal and oolitic limestone were deposited near the shore of the lake during its predominantly transgressive period (Douglas Creek time). During the predominantly regressive period (Evacuation Creek time) few beds of algal and oolitic limestone were formed. Bradley (1929, p. 223) stated that the scarcity of algal reefs may be ascribed to one or more of three possible causes: (1) increased concentration of sulfates in the lake, (2) a lessened quantity of lime in solution available for the formation of algal reefs, and (3) periodic evaporation of the lake during the normal growing season of the algae.

Fossils found in the Evacuation Creek Member consist of insects, insect larvae, leaves, and plant fragments. The age of the Evacuation Creek is generally considered to be middle Eocene; however, the upper part interfingers with beds considered to be late Eocene.

\section{TUFF BEDS IN THE GREEN RIVER FORMATION}

The marlstone and oil-shale sequence of the Parachute Creek and Evacuation Creek Members of the Green River Formation contains numerous beds of tuff and altered tuff. R. L. Griggs (written commun., 1961) stated, after studying thin sections of several tuff beds in the Uinta Basin, that -

the rocks examined were originally quartz latite or rhyolite tuffs composed chiefly of crystals and crystal fragments and interstitial glass. The crystalline portion generally makes up 10-80 percent of the rocks and is mainly quartz, sanidine, and sodic plagioclase, but some beds in the Evacuation Creek Member contain significant amounts of biotite and hornblende. The crystals and crystal fragments are not appreciably altered, but the interstitial glass has been altered to analcite and chalcedony or calcium carbonate.

The tuff beds range in thickness from a fraction of an inch to 20 feet and probably average less than 6 inches thick. Most of the tuffs are gray and weather tan to orange brown. The shades of gray range from light to dark, the intensity depending on the biotite content. The tuff beds vary greatly in resistance to erosion, and their topographic expression accordingly ranges from that of extensive benches to grooves in cliff faces.

The tuff beds have two general types of physical appearance. In one type the upper and lower surfaces of the beds are relatively smooth, and the beds show little or no internal bedding or grain orientation. In the second type, the beds have undulatory upper and lower surfaces, the undulations commonly being a few inches in amplitude; a maximum amplitude of 2 feet has been measured. The second type shows evidence of plastic flowage, such as contorted bedding and oriented crystals, and some beds contain inclusions of marlstone or oil shale. The irregular beds are a fraction of an inch to 20 feet thick, and most of them are less than 1 foot thick. The regularly bedded tuffs are a fraction of an inch to about 12 inches thick. Many evenly bedded tuffs have the appearance of fine-grained sandstone and have been described in some reports as sandstone. Tuff beds in and adjacent to the Mahogany ledge are locally saturated with a tarry substance that gives them the appearance of a bituminous sandstone.

TUFFACEOUS DIKES OF THE GREEN RIVER FORMATION

Sedimentary dikes containing large amounts of tuffaceous material were observed at several localities 
in the northwestern part of the area but were not mapped. They are associated with tuff beds in a stratigraphic sequence that extends 200 feet above and 200 feet below the Horse Bench Sandstone Bed.

R. I. Griggs examined seven thin sections from six dikes and three thin sections from two tuff beds associated with the dikes. He stated (written commun., 1961) that-

all the specimens are from altered quartz latite or rhyolite tuffs that originally consisted predominantly of crystals, and crystal fragments, of quartz, sanidine, and sodic plagioclase in a matrix of fine glass. Biotite and hornblende occur in all the rocks and, in some rocks, make up as much as 15 percent of an individual sumple. Apatite and zircon occur as accessory minerals in all the thin sections. The crystalline part of the sample has undergone only minor alteration. Virtually all the glass has been altered to analcite, chalcedony, and calcite or dolomite. In some thin sections of dike material the hornblende and biotite show the effects of solid flowage. The biotite crystals are bent around other grains, and the hornblende crystals are broken. However, it appears that some of the tuff was altered after the dikes were injected, because the analcite and chalcedony in the dike rock show no evidence of having been sheared after these minerals crystallized.

Small dikes a few inches high in cross section, that extend upward or downward from thin tuff beds into enclosing marlstone or siltstone can be seen at numerous localities. At three localities dikes cut several tens of feet of stratigraphic section: (1) the northwestern part of T. 14 S., R. 21 E., (2) the southwestern part of T. 11 S., R. 19 E., and (3) the southwestern part of T. 11 S., R. 21 E. Several dikes are exposed at each locality, and the following descriptions are based on studies of these dikes.

The rock in the dikes is more resistant to erosion than the wallrock and commonly projects a few inches above the surface of the less resistant marlstone that makes up most of the stratigraphic sequence into which the tuffaceous material was injected (fig. $5 B$ ). At one locality (fig. $5 A$ ) a dike projects 3 feet above the surface of the ground for a lateral distance of approximately 50 feet. Weathered dike rock is gray to dark reddish brown, and pieces of the the dark-colored contorted material can easily be identified on the light-colored marlstone slopes.

The dikes studied range in length from approximately 50 to 600 feet; most are 50-100 feet long. The 600-footlong dike occurs near Chimney Rock, in sec. 6, T. 14 S., R. $21 \mathrm{E}$. The dikes are a fraction of an inch to 20 inches wide, but most are less than 5 inches wide. Parts of individual dikes are relatively uniform in width and show little variation except for closely spaced parallel ridges and grooves formed by flowage against the bedding edges of fractured wallrock. Other parts of the dikes show extensive pinching and swelling, as well as small offshoots from the main dike. The width was apparently controlled by the amount of induration of the rock into which the dike was injected rather than by differences in the viscosity of the dike material. In no place were both the upper and lower terminations of a single dike exposed. A dike half a mile south of Chimney Rock was traced upward along a steep slope a vertical distance of 150 feet to a point where it merges with a contorted tuff bed. The lower limit could not be seen. This tuffaceous dike has the greatest vertical length of the dikes studied, and its intersection with a tuff bed is the only one clearly exposed. This intersection occurs about 20 feet below the Horse Bench Sandstone Bed on a hillside about half a mile south-southwest of Chimney Rock.

The trace of each dike is not a straight line either in plan or in cross section, but it is commonly more nearly linear in plan than in cross section. The dikes have randomly oriented strikes and are completely unrelated to the prominent joint system that was formed later than the fractures into which the dike material flowed and that cuts across the dikes. Also, the walls of the joints are extremely smooth and planar; their regularity indicates a greater degree of lithification at the time of their formation than at the time of the formation of the irregularly walled fractures which contain the dike material.

The conditions that produced the flowage of the tuff beds could not be conclusively established on the basis of information obtained in this study. It seems probable, however, that an appreciable amount of water was entrapped in the porous tuff beds by the overlying and underlying less permeable layers and that the water was a key factor in producing proper conditions for flowage. Water-saturated ash could have moved into incipient fractures either as a result of the increasing weight of overburden caused by continuing deposition or as a result of an increase in the volume of the tuff bed. Such a volume change might have been effected by the crystallization of analcite from a gel that formed from the original ash. Absence of shearing or distortion of the analcite crystals in the dike rock indicates, however, that the crystals were formed after the injection of the dikes. Possibly enough pressure was generated as the analcite crystallized in the bedded tuff to force a residue of gel into incipient fractures, where additional analcite then crystallized to form the groundmass of the dike rock.

\section{UINTA FORMATION}

Peterson (quoted in Osborn, 1895, p. 72-74) divided the sequence overlying the Green River Formation in the eastern Uinta Basin into three "horizons" which are, in ascending order: Horizon A, 800 feet of hard brown sandstone alternating with greenish-gray claystone; 


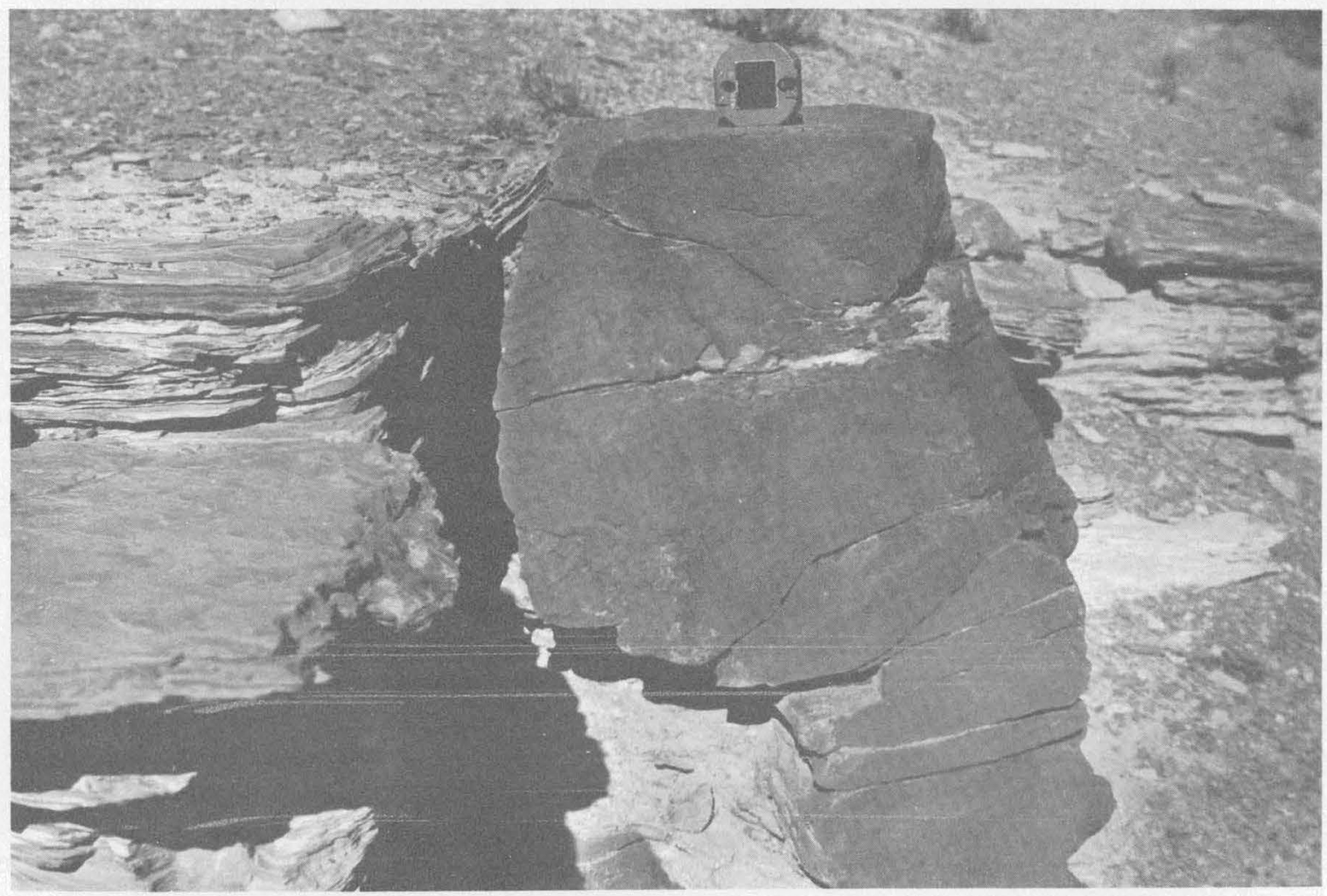

$A$

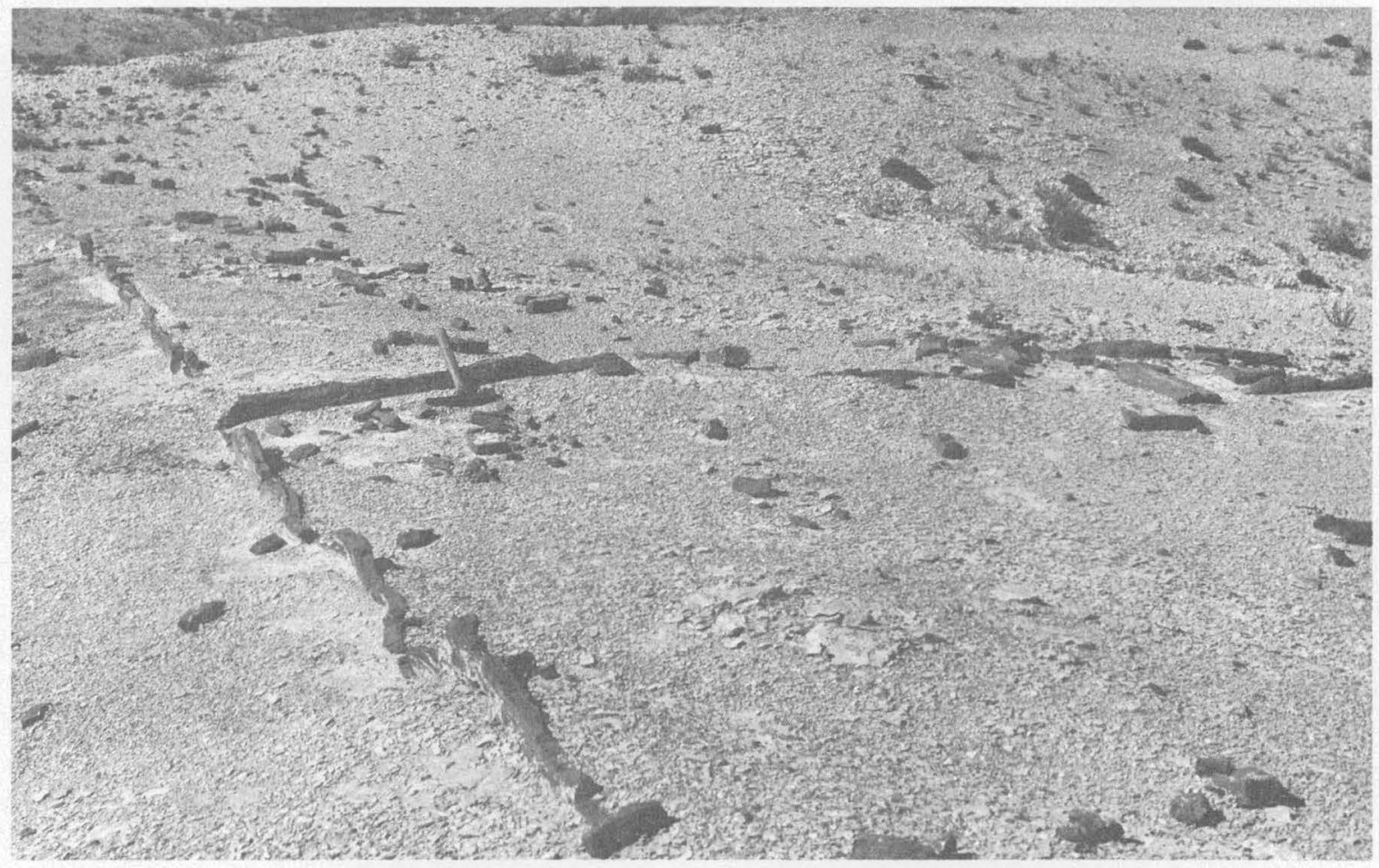

$B$

Figure 5.-Tuffaceous dikes. A, In the Parachute Creek Member near Chimney Rock, NE1/4NE1/4 sec. 6, T. 14 S., R. 21 E., Uintah County, Utah. Note inclusions of siltstone near center of photograph. $B$, In the Evacuation Oreek Member near Hatch Ranch, SW1/4NE1/4 sec. 31, T. 11 S., R. 21 E., Uintah County, Utah. 
horizon B, 350 feet of soft coarse sandstone and claystone; and horizon C, 600 feet of brown and red ferruginous sandstones and claystone. Peterson assigned horizon $\mathrm{A}$ to the Bridger Formation, horizon $\mathrm{B}$ to the Bridger and Uinta Formations, and horizon $\mathrm{C}$ to the Uinta Formation. In recent usage, however, the entire sequence has been referred to the Uinta Formation, and this usage is followed in this report.

Forizon $A$ and the lower part of horizon $B$ of the Uinta Formation are exposed along the northern margin. of the area. The formation commonly crops out in cliffs and broad resistant benches between drainages. In isolated outcrops it weathers to towerlike forms.

No complete stratigraphic section of the Uinta Formation was measured, and thickness estimates are based on that part of the formation which occurs within the mapped area. Maximum thickness of the part exposed within the mapped area is an estimated 1,000 feet in the northeastern part of the area and an estimated 400 feet in the northwestern part.

The Uinta Formation conformably overlies and interfingers with the Green River Formation. The Green River-Uinta contact is drawn at the base of the lowermost massive resistant fluvial sandstone bed in the Uinta. Owing to the westward pinchout of sandstone beds in the lower part of the Uinta Formation, the base of the formation along the Green River is 500 feet higher stratigraphically than it is along the White River. In much of the area northeast of Bitter Creek, the contact between the Uinta and Green River Formations though undulatory lies mainly at one stratigraphic horizon. This undulatory boundary is apparently the result of differential compaction or of plastic flowage of the massive contorted tuffaceous sandstone sequence in the basal part of the Uinta Formation. The character of this contorted sandstone sequence in the Uinta Basin is very similar to that described by Culbertson (1962) and by Rapp (1962) for certain sandstone lentils and beds in the Laney Shale Member of the Green River Formation in the Green River basin, Wyoming. The age relation of the two sequences is not known. To the east and west, the contorted sandstone pinches out, and stratigraphically higher massive fluvial sandstone rest conformably on marlstone of the Green River Formation.

The Uinta Formation is overlain by the Duchesne River Formation. In the central part of the Uinta Basin the contact between the two formations is conformable. Along the northern margin of the basin, however, the Duchesne River Formation rests unconformably on the Uinta Formation and older rocks. In the area of this report, the Duchesne River Formation may rest unconformably on the Uinta Formation and the upper part of the Green River Formation. The relationship is not clear, however, owing to poor exposures.

Source, environment, and fossils

Sourees of the Uinta Formation lay to the east and to the north of the Uinta Basin. Surface studies of facies changes in the mapped area indicate a northern or northeastern source for the basal part of the Uinta Formation. Stagner (1941, p. 284-297), who made a detailed study of stream channels in the "Uinta B member," presented several types of evidence which showed that most of the sediments in the "Uinta B member" were derived from an eastern source, and he postulated, on the basis of reconnaissance studies, that much of the sediment in the "Uinta A member" was derived from an eastern source. Stagner (1941, p. 295) concluded that the mineralogy of pebbles and sand which he found in the stream deposits implied a source that may have been as far east as the Park Range, Colo.

Most sediments in the Uinta Formation were deposited in streams and on flood plains that formed during (and after) the major waning phase of the lake that lay just south of the Uinta Mountains. The lower part of the Uinta Formation in the eastern part of the mapped area contains some thin shaly units that were deposited in a lacustrine environment and the massive contorted basal sandstone may have been laid down in a delta along the margin of the lake.

The Uinta Formation has yielded numerous key fossils, especially vertebrates. Kay (1957, p. 111-114), who termed the Uinta Formation a "classical collecting ground" for late Eocene fossil vertebrates, discussed the fauna of the formation and listed many of its fossil vertebrates.

\section{DUCHESNE RIVER FORMATION}

The Duchesne River Formation was named by Kay (1934, p. 358-359) for exposures in the north-central part of the Uinta Basin. The formation underlies less than 1 square mile in the northernmost part of the mapped area. Here the formation is composed of red and gray poorly cemented sandstone and arenaceous shale. The Duchesne River Formation weathers to a badlands topography. In the mapped area the Duchesne River Formation may rest unconformably on the Green River and Uinta Formations, but in the central part of the Uinta Basin it rests conformably on the Uinta Formation. The sediments of the fluvially deposited Duchesne River were derived from the Uinta Mountain area. The Duchesne River Formation is considered to be Eocene or Oligocene in age. 


\section{QUATERNARY SYSTEM}

Quaternary rocks in the mapped area consist chiefly of alluvial deposits along all the major stream valleys. These deposits are composed of silt- to boulder-sized pieces of marlstone, siltstone, and sandstone.

Sparse patches of cemented colluvial deposits were noted in canyons near the Green River. These patches, seen at a few scattered localities, are too small to be shown on the geologic map, plate 1 . The colluvium is composed of sandstone and marlstone that are well cemented by calcium carbonate and are also cemented to the steep canyon walls. The colluvial deposits are a few tens of feet in diameter and have a maximum thickness of about 10 feet.

\section{STRUCTURE}

The Uinta Basin is a structurally asymmetric depression having steeply inclined rocks along its north flank. Most of the mapped area lies on the south flank of the basin. Within the mapped area the basin axis is just southwest of Raven Ridge. The inclination of the beds is greatest in the northeastern part of the area and decreases to the south and southwest. Angles of dip range from about $35^{\circ}$ at Raven Ridge to about $1^{\circ}$ at several localities in the west half of the area. Northeast of Bitter Creek the strata have moderate to steep dips, and several anticlinal noses interrupt the predominant structural trend. These structural noses, which plunge westward from the Douglas Creek arch, are most conspicuous in the northern part of the area, for the magnitude of folding decreases southward. Southwest of Bitter Creek the beds have gentle dips, and the structure is mainly that of a north-dipping homocline. The only major interruption in this northward dip is the Hill Creek anticline, which is mainly a northwest-plunging fold that has about 75 feet of surface closure in a small area near the southwest corner of T. 14 S., R. 20 E.

Faulting is minor in the area. Neither the density of faults nor the displacement of individual faults is of appreciable magnitude. The greatest density of faults occurs northeast of Evacuation Creek in the area having the most folds. The predominant strike of these faults is northeast. The maximum displacement along individual faults is $10-200$ feet, and the fault planes are vertical, or nearly so. The density of faults is very low southwest of Evacuation Creek, where most faults trend northwest and bound small grabens. Displacement is $15-50$ feet, and the fault planes are vertical, or nearly so. At two localities near Sand Wash Ferry, the lower ends of the faults can be seen. At each locality a fault terminates downward in a fold in the thinbedded marlstone of the Parachute Creek Member. On the basis of observations at these two localities and of the relatively small displacements of the faults, no fault in the mapped area is assumed to extend to a great depth. Because some groups of grabens in the area southwest of Evacuation Creek are parallel to the Uncompahgre uplift, however, the grabens are postulated to be related to deep-seated faults or folds that resulted from movement along the flank of the uplift.

A prominent system of joints is present in the Green River strata. This system consists of two sets of vertical joints, whose character is shown in figure 6 . The strike of these northwest- and northeast-trending sets differs in various parts of the area. The most numerous and the most closely spaced joints occur in the thinbedded marlstone and siltstone, although some also occur in the coarser grained strata. The orientation of many small stream valleys in the area is controlled by the joint system. Gilsonite veins occur along some

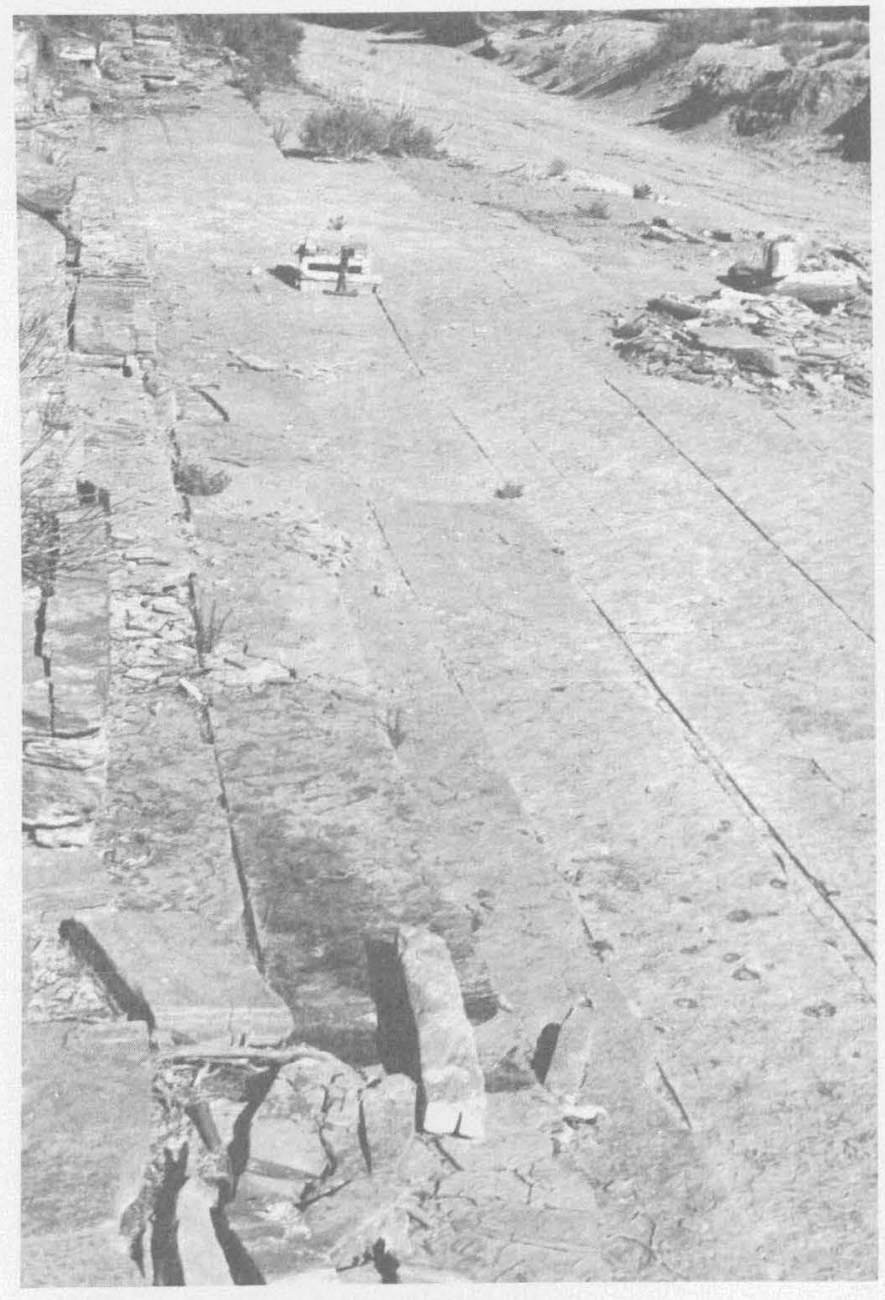

Frgure 6.-Jointing in the Horse Bench Sandstone Bed of the Evacuation Creek Member, sec. 9, T. 13 S., R. 20 E., Uintah County, Utah. Note ripple marks (lower left). 
northwest-trending joints in part of the area. At several localities walls of the joints containing the gilsonite veins are offset $2-3$ feet.

The joint system is evidently the result of forces that developed at some time after the deposition of the Uinta Formation and during the downwarping of the basin. The opening of the joints to allow the entry of gilsonite probably occurred during a later period of folding.

Several minor folds are present in T. 13 S., Rs. 20 and $21 \mathrm{E}$, and similar folds are probably present elsewhere in the northwestern part of the area. One of the folds examined is shown in figure 7 . The folding is most evident in a thin resistant tuffaceous siltstone bed that is overlain and underlain by thin-bedded nonresistant marlstone. The siltstone bed, about 1 foot thick, forms an extensive bench about 100 feet above the Mahogany oil-shale bed. Throughout most of their length the folds have been breached, and the nature of their crests cannot be determined. Near the ends of the doubly plunging folds, where the heights and widths can be measured in inches, the apexes are visible. At some of these exposures, one limb appears to have been thrust a few inches over the other. The folds have steeply dipping limbs, and a cross section of a restored fold would probably have the appearance of an inverted V. The bedding of the nonresistant marlstone above the folded siltstone bed could not be seen and rocks below the bed were seen at only one locality. There, the rocks below the folded siltstone were not folded. The axes are slightly sinuous. Maximum width of a single fold is about 8 feet, and maximum length is about 200 feet.

Folds similar to those just described have been attributed to (1) glacial action, (2) downslope creep of surface rocks, (3) recrystallization of the rock, (4) water freezing in joints, and $(5)$ increase in volume of the rock due to weathering. Because of the symmetry of the folds and the absence of evidence of glaciation, possible causes 1 and 2 are rejected by the author. The folds were apparently the result of a change in the volume of the rock or of the material adjacent to the rock and thus could have been caused by either 3,4 , or 5 .

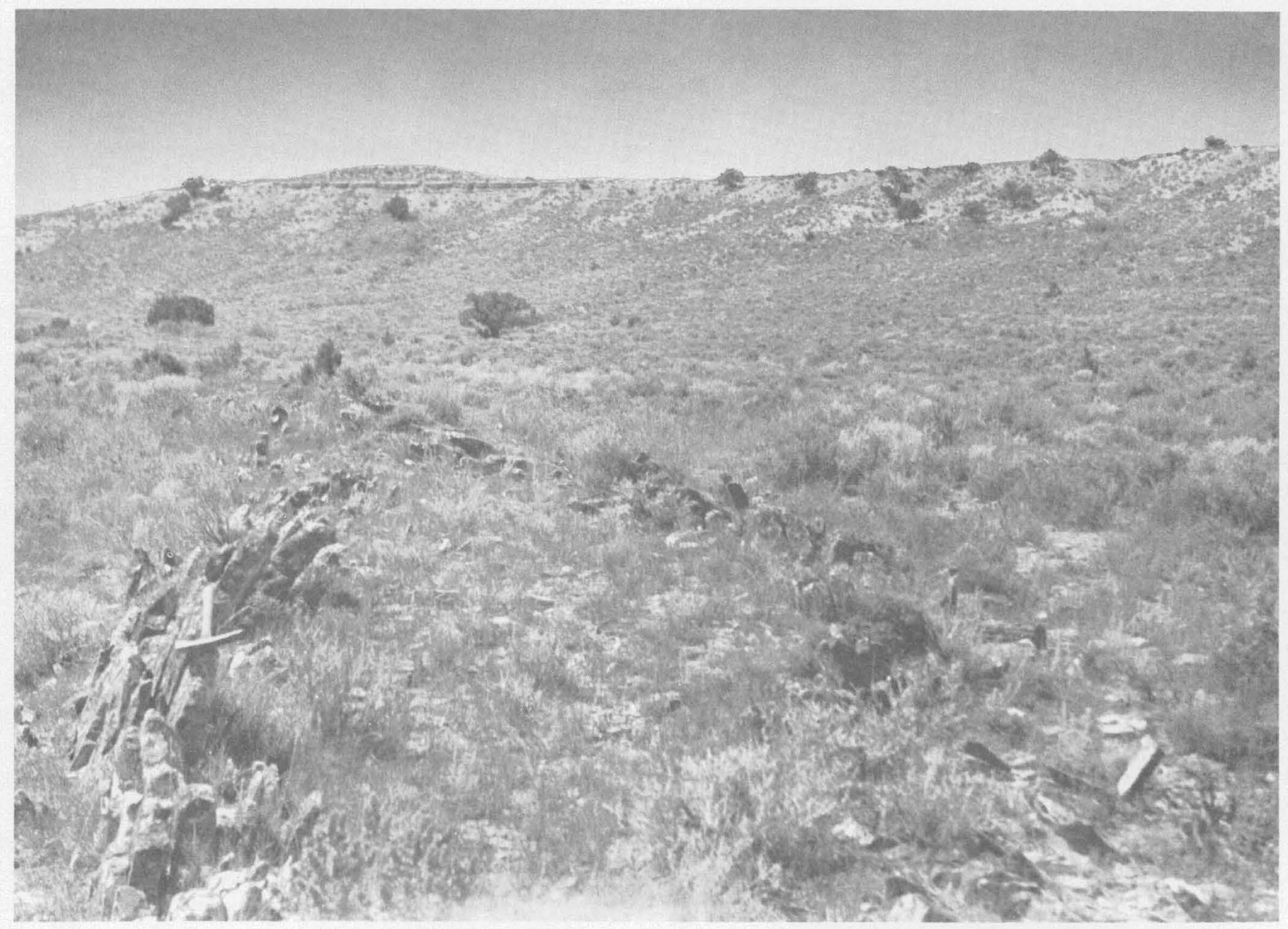

FIGURE 7.-Minor fold in a siltstone bed of the Parachute Creek Member, NE1/4 sec. 7, T. 13 S., R. 21 E., Uintah County, Utah. 


\section{ECONOMIC GEOLOGY}

OIL SHALE

\section{COMPOSITION AND PHYSICAL CHARACTERISTICS}

Oil shale has been defined in various ways (Bradley, 1931 , p. 7-8). In this report, however, the term "oil shale" is used for marlstone that, when distilled, will yield 15 gallons or more of oil per ton. This usage is based on present oil-shale technology.

The physical and mineralogic characteristics of the oil shale of the Green River Formation were described in detail by Bradley (1931, p. 22-37, 39-40). Some salient characteristics of the oil shales are as follows:

1. The oil shales are composed of magnesian marlstone having a high content of organic matter.

2. The predominant inorganic constituents are dolomite, calcite, and clay minerals.

3. Clastic minerals such as quartz, sanidine, feldspar, muscovite, zircon, and apatite occur in minor amounts and are partly of volcanic origin.

4. Syngenetic analcite in crystalline form and pyrite in disseminated form occur in many of the oil-shale beds.

5 . The organic matter is of two types. One type is structureless, translucent, and lemon yellow to reddish brown. The other type consists of complete or fragmentary organisms such as algae, protozoa, and insects, and parts of higher plants-spores, pollen grains, and minute pieces of tissue.

The oil-shale beds are generally thin and regular. Many of the moderately rich oil-shale sequences are varved, consisting of alternating laminae of dark organic-rich material and light mineral-rich material. Kerogen-rich oil-shale beds weather to distinctive bluish-gray ledges. The degree of resistance to erosion and the darkness of color of the outcrop are in direct proportion to the content of organic matter. Unweathered oil shale ranges from tan or brown in the low-grade oil shale to very dark gray in the high-grade oil shale. Kerogen-rich beds are tough and resilient, whereas beds containing only a small amount of kerogen are brittle. A sliver of the oil shale that yields more than 35 gallons of oil per ton will burn for a short period of time when heated with a match. The specific gravity of oil shale is inversely proportional to the potential shale-oil yield. Oil shale that will yield 15 gallons of oil per ton has an average specific gravity of about 2.38, and oil shale that will yield 100 gallons of oil per ton has an average specific gravity of about 1.40 (Stanfield and others, 1957, p. 5-6). Oil shale will yield free shale oil when heated in a closed system. Part of the organic matter changes from a solid to a gas, most of which, upon cooling, condenses to form oil.

\section{DEVELOPMENT}

Shale oil has not been produced on a large commercial scale in this country. However, since World War I there has been fluctuating interest in oil shale as a possible source of liquid fuel. Early activities involved the construction of a few experimental retorts, small-scale open-pit mining, and the digging of many evaluation pits. In recent years the oil-production activity in the Uinta Basin has consisted of core-drilling operations and the leasing or buying of available oilshale land, whereas advances made in oil-shale mining and in retorting technology have resulted mainly from activities in the Piceance Creek basin of Colorado. From 1945 through 1956 the U.S. Bureau of Mines operated an experimental oil-shale mine and retort near Rifle, Colo. In the same general area, Union Oil Co. of California conducted experimental mining and retorting operations, and Sinclair Oil Co. investigated the feasibility of retorting oil shale in place. The Denver Research Inst., under contract to the Oil Shale Corp., has operated a pilot plant to perfect a retorting procedure known as the Aspeco Process. In 1960 a small chemical explosive experiment was conducted at the U.S. Bureau of Mines underground workings near Rifle. This experiment was a part of a study made by the Lawrence Radiation Laboratory of the problems associated with the recovery of petroleum products from oil shale by means of nuclear explosive energy. The results of the experiment were described by Adelman, Bacigalupi, and Momyer (1960).

\section{POTENTIAL RESERVES}

Because' oil-shale deposits in the United States are not being commercially developed at present but perhaps will be developed in the future, they can be considered as potential reserves or resources. At present, the average grade of oil shale that will eventually prove most suitable for retorting and the minimum minable thickness are not assuredly predictable. For the processes used in research at the U.S. Bureau of Mines plant near Rifle, oil shale ranging in grade from 25 to 33 gallons of oil per ton seemed to be best suited for retorting, and a minimum thickness of 25 feet appeared necessary for the most effective mining. However, other types of retorts and mining equipment require different grades and thicknesses of oil shale. Advancements in the technology of mining and processing oil shale and changes in certain economic factors may alter these requirements; therefore, three grades of oil shale (yielding 15, 25, and 30 gallons per ton) and a minimum thickness of 15 feet are discussed in this report. 
Methods used in computing estimates of potential reserves Reserve computations in this report are based on oilyield assays of cores, drill cuttings, and outcrop samples, and on oil-yield estimates of outcrop samples. Most of the assayed samples were processed by the U.S. Bureau of Mines by use of the modified Fischer method, as described by Stanfield, Frost, McAuley, and Smith (1951). For each locality where samples of the oilshale sequence were obtained, the gallons-per-ton assays and the thickness of the bed represented by the simple were used to calculate the maximum thicknesses of the continuous sequence that has an average oil yield of (1) 30 gallons of oil per ton, (2) 25 gallons per ton, and (3) 15 gallons of oil per ton. Sequence 2 includes the rocks that make up sequence 1 , and sequence 3 includes the rocks that make up sequence 2 . These sample localities (or control points) were used to construct thickness maps for the three grades of oil shale: yielding an average of 15,25 , or 30 gallons per ton (pl. 5). Average thickness of each grade of shale was then estimated for each township, and the volume of oil shale of each grade was computed and converted to tons. Finally, the yield of oil, in barrels, was computed from the tonnage and the average grade of the shale.

The basic information on potential oil yield generally consists of individual assays of a series of samples taken from a stratigraphic sequence. The samples are varied both in thickness of strata represented and in oil yield. When assay data of a series of samples were combined for determination of the average oil yield of the total thickness, values of the individual samples were weighted according to both the thickness of the strata represented and the specific gravity.

Samples from 39 core holes and 20 exploratory wells in the mapped area were assayed for oil yield by the U.S. Bureau of Mines. Eighteen of the core holes were drilled in Naval Oil-Shale Reserve No. 2, and the results of the assays were discussed by Cashion (1959). Oil-yield data for all the 39 core holes and 20 exploratory wells were presented by Stanfield, Rose, McAuley, and Tesch $(1954$, p. 123-126, 129; 1964). Assays and oil-yield estimates of surface samples are shown on plates 3 and 4 . The oil yield of the surface rocks is decreased by weathering; therefore, oil yield data from surface-rock samples were used only when no other data were available.

In computation of the reserves of shale oil, a potential oil yield of 1,157 barrels per acre foot was assumed for "15-gallon" shale, 1,791 barrels per acre foot for "25-gallon" shale, and 2,078 barrels per acre foot for "30-gallon" shale. These figures are based on information given by Stanfield, Rose, McAuley, and Tesch (1957, p. 2-5).

\section{Classiflcation of reserves}

The potential reserves described in this report are divided into two categories-indicated and inferredaccording to the reliability of the data. This classification is patterned after that used by Donnell (1957, 1961) when he estimated oil-shale reserves of the Piceance Creek basin. The accuracy of the estimates depends mainly on the reliability of sample data and the spacing of control points. The most reliable oilyield data were obtained from assayed samples that were unweathered, uncontaminated, and properly correlated with the stratigraphic section. Weathered oilshale beds have lost part of their original organic matter; therefore, assays of samples from a weathered bed indicate a lower oil yield than do assays of samples from the same bed where it is unweathered. For example, a sample of weathered oil shale from the Mahogany bed assayed at 12.8 gallons of oil per ton, whereas an unweathered sample taken from close by but 2 feet beneath the surface assayed at 45.5 gallons of oil per ton (Guthrie, 1938, p. 99). Although oil-yield assays of weathered strata are known to be lower than assays of the same strata where they are not weathered, a constant upgrading factor cannot be applied because of great variation in the weathering of oil-shale beds. Oil-yield assays of contaminated samples may be higher or lower than the actual oil yield-the direction of the variation depending on the degree of contamination and on the oil yield of the contaminating rock fragments. The potential oil yield of surface samples can be estimated with moderate accuracy by an experienced investigator who considers color, sheen, and specific gravity. Such estimates tend to be low, however, and were used in this report only when assay data were not available.

Estimates of indicated potential reserves are based on assays of samples from core holes and of drill cuttings from exploratory wells. Because of the possibility of contamination or of human error in the collection of drill cuttings, and because drill-cutting samples represent thick sample units (generally $10 \mathrm{ft}$ thick), coresample assays are more reliable. Assays of cuttings are adequate, however, for estimation of indicated potential reserves-unless these assays are completely anomalous with those from nearby control points and with known geology. Estimates of inferred potential reserves are based on assays of outcrop samples or on interpolation between widely spaced core holes or exploratory wells. In estimating reserves, core-hole and exploratory-well localities are designated as primary control points, and surface sections, as secondary control points. Mapped areas of indicated potential reserves are delineated by an encircling boundary drawn approximately 2 miles from 
an isolated primary control point, or approximately 2 miles from the outermost primary control points of a group in which any two adjacent points are less than 6 miles apart. Areas of inferred potential reserves are delineated by boundaries drawn by the use of data from secondary control points and widely spaced primary control points.

\section{summary of reserves}

The estimates of tonnage and of potential oil yield of oil shale in the mapped area are for total oil shale in place and for total potential oil yield; these estimates are based on the assumption that all the oil could be extracted from the deposit. The amount of recoverable oil would undoubtedly be less than the total potential oil yield, owing to losses in mining and processing, and would perhaps be further decreased by cutoff limits of grade, depth, thickness, or distance from outcrop.

Estimates of tonnage and potential oil yield of that part of the Mahogany zone and adjacent beds which is in a continuous sequence at least 15 feet thick and which yields an average of 30 gallons oil per ton are shown in table 1 , and the thickness and distribution are shown on plate $5 C$. An area of approximately 195 square miles contains indicated reserves of about 11.76 billion tons of shale having a potential yield of about 8.4 billion barrels of oil. Of this total oil reserve, 8.34 billion barrels is in Utah and the rest is in Colorado. Approximately 266 square miles cont ins inferred reserves of about 14.5 billion tons of shale having a potential yield of about 10.35 billion barrels of oil. Of this inferred reserve, 10.3 billion barrels is in Utah and the rest is in Colorado.

Estimates of tonnage and potential oil yield of that part of the Mahogany zone and adjacent beds which yield an average of 25 gallons oil per ton in a continuous sequence at least 15 feet thick are shown in table 2 , and the thickness and distribution are shown on plate $5 B$. This sequence includes the shale that yields an average of 30 gallons oil per ton (table 1). Indicated reserves of about 22.12 billion tons of shale having a potential yield of about 13.16 billion barrels of oil underlie an area of approximately 274 square miles. Of this total oil reserve, about 13.01 billion barrels is in Utah, and the rest is in Colorado. Inferred reserves of about 23.3 billion tons of shale that will yield about 13.88 billion barrels of oil underlie an area of approximately 297 square miles. Of this total, about 13.76 billion barrels is in Utah, and the rest is in Colorado.

Estimates of tonnage and potential oil yield of that part of the Mahogany zone and adjacent beds which yields an average of 15 gallons oil per ton in a continu- ous sequence at least 15 feet thick are shown in table 3, and the thickness and distribution are shown on plate $5 A$. This sequence includes the shale of the two grades previously discussed (tables 1,2). An area of approximately 315 square miles contains indicated reserves of about 77.2 billion tons of shale having a potential oil yield of about 27.6 billion barrels. Of this reserve, about 27.18 billion barrels is in Utah, and the rest is in Colorado. The approximately 376-square-mile area contains inferred reserves of about 72.8 billion tons of shale having a potential oil yield of about 26 billion barrels of oil. Of this total, 24.78 billion barrels is in Utah, and the rest is in Colorado.

\section{O11-shale areas most favorable for future development}

The most favorable area for future development of an oil-shale industry seems to be near the White River in Tps. 9 and 10 S., R. 25 E. The thickest sequence of rich oil shale is exposed here, and water for industrial plant use is available nearby in the White River. The crude-oil pipeline connecting the Rangely oil field and Salt Lake City passes through the northern part of the mapped area and could possibly transport the shale oil to market. The most convenient railroad shipping point, Craig, Colo., is about 100 miles away. Much of the rich oil shale in the area near the White River is overlain by several hundred feet of overburden, which would probably necessitate underground mining or recovery of oil from the shale in place.

No strip mining of oil shale has been done on a commercial basis in the United States; therefore, no data on the requirements of such an operation in this country are available. Many areas, of various sizes, in the southeastern part of the Uinta Basin, may be suitable for strip mining. The general location of a few of the larger areas are (1) along McCook Ridge, in T. 13 S., Rs. 23 and 24 E., (2) along the ridge just north of Burnt Timber Canyon, in T. 13 S., Rs. 24 and 25 E., and (3) along the ridges between Agency Draw and Willow Creek, in Tps. 12 and 13 S., R. 21 E. Each area contains several hundred acres in which the overburden above the Mahogany zone is 100 feet thick or less. The thickness of shale in these areas where the shale yields an average of 15,25 , or 30 gallons of oil per ton is shown on plate 5 .

\section{Oil-shale resources of the Uinta Basin}

A major part of the oil-shale resources, or potential reserves, of the Uinta Basin occurs outside the mapped area. The entire basin must consequently be considered when its oil-shale resources are evaluated. Preliminary estimates of the oil-shale resources of the entire basin are therefore included in this report. 
TABLE 1.-Estimated tonnage and potential oil yield of that part of the Mahogany zone and adjacent beds occurring in a continuous sequence at least 15 feet thick and yielding an average of 30 gallons oil per ton

[Estimates include the total tonnage and total potential oil yield of the deposit; no allowances were made for losses in mining or processing. Totals for indicated and inferred potential reserves given at the bottom of columns $3,7,8]$

\begin{tabular}{|c|c|c|c|c|c|c|c|}
\hline \multicolumn{2}{|c|}{ Location } & \multirow{2}{*}{ Acreage } & \multirow{2}{*}{$\begin{array}{l}\text { Average thickness } \\
\text { of oil shale (feet) }\end{array}$} & \multirow{2}{*}{$\begin{array}{c}\text { A verage tonnage } \\
\text { per acre of oil } \\
\text { shale (thousands of } \\
\text { tons) }\end{array}$} & \multirow{2}{*}{$\begin{array}{l}\text { Average oil yield } \\
\text { per acre (thousands } \\
\text { of barrels) }\end{array}$} & \multirow{2}{*}{$\begin{array}{l}\text { Tonnage of oil } \\
\text { shale (millions of } \\
\text { tons) }\end{array}$} & \multirow{2}{*}{$\begin{array}{c}\text { Potential oil } \\
\text { yield (millions of } \\
\text { barrels) }\end{array}$} \\
\hline Township & Range & & & & & & \\
\hline \multicolumn{8}{|c|}{ INDICATED POTENTIAL RESERVES } \\
\hline \multicolumn{8}{|c|}{ Colorado } \\
\hline $\begin{array}{l}1 \mathrm{~N} . \\
1 \mathrm{~S} .\end{array}$ & $\begin{array}{l}104 \mathrm{~W} . \\
104 \mathrm{~W} .\end{array}$ & $\begin{array}{l}116 \\
770\end{array}$ & $\begin{array}{l}26 \\
34\end{array}$ & $\begin{array}{l}\text { 75. } 7 \\
98.9\end{array}$ & $\begin{array}{l}54.1 \\
70.6\end{array}$ & $\begin{array}{r}9 \\
76\end{array}$ & $\begin{array}{r}6 \\
54\end{array}$ \\
\hline \multicolumn{8}{|c|}{ Utah } \\
\hline $\begin{array}{c}9 \mathrm{~S} . \\
10 \mathrm{~S} . \\
11 \mathrm{~S} . \\
12 \mathrm{~S} . \\
13 \mathrm{~S} .\end{array}$ & $\begin{array}{l}24 \mathrm{E} . \\
25 \mathrm{E} . \\
24 \mathrm{E} . \\
25 \mathrm{E} . \\
18 \mathrm{E} . \\
19 \mathrm{E} . \\
20 \mathrm{E} . \\
24 \mathrm{E} . \\
25 \mathrm{E} . \\
18 \mathrm{E} . \\
19 \mathrm{E} . \\
20 \mathrm{E} . \\
21 \mathrm{E} . \\
24 \mathrm{E} . \\
25 \mathrm{E} . \\
18 \mathrm{E} . \\
19 \mathrm{E} . \\
20 \mathrm{E} . \\
21 \mathrm{E} . \\
24 \mathrm{E} . \\
25 \mathrm{E} .\end{array}$ & $\begin{array}{r}700 \\
8,801 \\
5,466 \\
11,780 \\
2,755 \\
3,260 \\
362 \\
13,050 \\
13,862 \\
2,475 \\
14,288 \\
15,573 \\
2,508 \\
14,900 \\
3,840 \\
456 \\
2,980 \\
2,537 \\
1,073 \\
3,262 \\
300\end{array}$ & $\begin{array}{l}46 \\
39 \\
64 \\
46 \\
19 \\
27 \\
28 \\
42 \\
36 \\
18 \\
20 \\
23 \\
20 \\
32 \\
30 \\
17 \\
17 \\
19 \\
16 \\
26 \\
25\end{array}$ & $\begin{array}{r}133.9 \\
113.5 \\
186.2 \\
133.9 \\
55.3 \\
78.6 \\
81.5 \\
122.2 \\
104.8 \\
52.4 \\
58.2 \\
66.9 \\
58.2 \\
93.1 \\
87.3 \\
49.5 \\
49.5 \\
55.3 \\
46.6 \\
75.7 \\
72.7\end{array}$ & $\begin{array}{r}95.6 \\
81.1 \\
133.0 \\
95.6 \\
39.5 \\
56.1 \\
58.2 \\
87.3 \\
74.9 \\
37.4 \\
41.6 \\
47.8 \\
41.6 \\
66.5 \\
62.4 \\
35.4 \\
35.4 \\
39.5 \\
33.3 \\
54.1 \\
51.9\end{array}$ & $\begin{array}{r}94 \\
999 \\
1,018 \\
1,577 \\
152 \\
256 \\
30 \\
1,595 \\
1,453 \\
130 \\
832 \\
1,042 \\
146 \\
1,387 \\
335 \\
23 \\
147 \\
140 \\
50 \\
247 \\
22\end{array}$ & $\begin{array}{r}67 \\
714 \\
727 \\
1,126 \\
109 \\
183 \\
21 \\
1,139 \\
1,038 \\
93 \\
594 \\
744 \\
104 \\
991 \\
240 \\
16 \\
105 \\
100 \\
36 \\
176 \\
16\end{array}$ \\
\hline & & 125,114 & 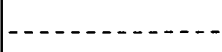 & 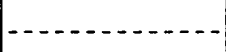 & 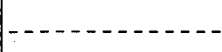 & 11,760 & 8,399 \\
\hline \multicolumn{8}{|c|}{ INFERRED POTENTIAL RESERVES } \\
\hline \multicolumn{8}{|c|}{ Colorado } \\
\hline $\begin{array}{l}1 \mathrm{~S} . \\
2 \mathrm{~S} .\end{array}$ & $\begin{array}{l}104 \mathrm{~W} . \\
104 \mathrm{~W} .\end{array}$ & $\begin{array}{l}565 \\
320\end{array}$ & $\begin{array}{l}21 \\
18\end{array}$ & $\begin{array}{l}61.1 \\
52.4\end{array}$ & $\begin{array}{l}43.6 \\
37.4\end{array}$ & $\begin{array}{l}35 \\
17\end{array}$ & $\begin{array}{l}25 \\
12\end{array}$ \\
\hline \multicolumn{8}{|c|}{ Utah } \\
\hline $\begin{array}{l}9 \mathrm{~S} . \\
10 \mathrm{~S} . \\
11 \mathrm{~S} .\end{array}$ & $\begin{array}{l}24 \mathrm{E} . \\
25 \mathrm{E} . \\
24 \mathrm{E} . \\
18 \mathrm{E} . \\
19 \mathrm{E} . \\
20 \mathrm{E} . \\
21 \mathrm{E} . \\
24 \mathrm{E} . \\
25 \mathrm{E} . \\
20 \mathrm{E} . \\
21 \mathrm{E} . \\
22 \mathrm{E} . \\
23 \mathrm{E} . \\
24 \mathrm{E} . \\
21 \mathrm{E} . \\
22 \mathrm{E} . \\
23 \mathrm{E} . \\
24 \mathrm{E} . \\
25 \mathrm{E} .\end{array}$ & $\begin{array}{r}11,092 \\
4,495 \\
3,552 \\
12,035 \\
15,730 \\
18,400 \\
6,400 \\
1,970 \\
1,769 \\
6,887 \\
13,282 \\
15,360 \\
17,030 \\
6,740 \\
3,117 \\
18,700 \\
9,520 \\
2,830 \\
650\end{array}$ & $\begin{array}{l}40 \\
28 \\
65 \\
21 \\
29 \\
32 \\
31 \\
40 \\
21 \\
28 \\
27 \\
30 \\
32 \\
33 \\
20 \\
22 \\
22 \\
26 \\
20\end{array}$ & $\begin{array}{r}116.4 \\
81.5 \\
189.1 \\
61.1 \\
84.4 \\
93.1 \\
90.2 \\
116.4 \\
61.1 \\
81.5 \\
78.6 \\
87.3 \\
93.1 \\
96.0 \\
58.2 \\
64.0 \\
64.0 \\
75.7 \\
58.2\end{array}$ & $\begin{array}{r}83.1 \\
58.2 \\
135.1 \\
43.6 \\
60.3 \\
66.5 \\
64.4 \\
83.1 \\
43.6 \\
58.2 \\
56.1 \\
62.4 \\
66.5 \\
68.6 \\
41.6 \\
45.7 \\
45.7 \\
54.1 \\
41.6\end{array}$ & $\begin{array}{r}1,291 \\
366 \\
672 \\
735 \\
1,328 \\
1,713 \\
577 \\
229 \\
108 \\
561 \\
1,044 \\
1,341 \\
1,585 \\
647 \\
181 \\
1,197 \\
609 \\
214 \\
38\end{array}$ & $\begin{array}{r}922 \\
262 \\
480 \\
525 \\
948 \\
1,224 \\
412 \\
164 \\
77 \\
401 \\
745 \\
958 \\
1,132 \\
462 \\
130 \\
855 \\
435 \\
153 \\
27\end{array}$ \\
\hline & & 170,444 & $-\ldots$ & - & - & 14,488 & 10,349 \\
\hline
\end{tabular}


TABLE 2.-Estimated tonnage and potential oil yield of that part of the Mahogany zone and adjacent beds occurring in a continuous sequence at least 15 feet thick and yielding an average of 25 gallons oil per ton

[Estimates include the total tonnage and total potential oil yield of the deposit; no allowances were made for losses in mining or processing. Estimates include the rock containing potential reserves shown in table 1 . Totals for indicated and inferred potential reserves given at the bottom of columns $3,7,8$ ]

\begin{tabular}{|c|c|c|c|c|c|c|c|}
\hline \multicolumn{2}{|c|}{ Location } & \multirow{2}{*}{ Acreage } & \multirow{2}{*}{$\begin{array}{l}\text { Average thickness } \\
\text { of oil shale (feet) }\end{array}$} & \multirow{2}{*}{$\begin{array}{c}\text { Average tonnage } \\
\text { per acre of oil } \\
\text { shale (thousands of } \\
\text { tons) }\end{array}$} & \multirow{2}{*}{$\begin{array}{l}\text { Average oil yield } \\
\text { per acre (thousands } \\
\text { of barrels) }\end{array}$} & \multirow{2}{*}{$\begin{array}{l}\text { Tonnage of oil } \\
\text { shale (millions of } \\
\text { tons) }\end{array}$} & \multirow{2}{*}{$\begin{array}{l}\text { Potential oil } \\
\text { yield (millions of } \\
\text { barrals) }\end{array}$} \\
\hline Township & Range & & & & & & \\
\hline
\end{tabular}

INDiCATED POTENTIAL RESERVES

\begin{tabular}{|c|c|c|c|c|c|c|c|}
\hline \multicolumn{8}{|c|}{ Colorado } \\
\hline $\begin{array}{ll}1 & \mathrm{~N} . \\
1 \mathrm{~S} .\end{array}$ & $\begin{array}{l}104 \mathrm{~W} . \\
104 \mathrm{~W} .\end{array}$ & $\begin{array}{l}319 \\
770\end{array}$ & $\begin{array}{l}37 \\
58\end{array}$ & $\begin{array}{l}111.7 \\
175.2\end{array}$ & $\begin{array}{r}66.5 \\
104.3\end{array}$ & $\begin{array}{r}36 \\
135\end{array}$ & $\begin{array}{l}21 \\
80\end{array}$ \\
\hline \multicolumn{8}{|c|}{ Utah } \\
\hline $\begin{array}{c}9 \mathrm{~S} . \\
10 \mathrm{~s} . \\
11 \mathrm{~S} . \\
12 \mathrm{~S}\end{array}$ & $\begin{array}{l}24 \mathrm{E} . \\
25 \mathrm{E} . \\
24 \mathrm{E} . \\
25 \mathrm{E} . \\
18 \mathrm{E} . \\
19 \mathrm{E} . \\
20 \mathrm{E} . \\
24 \mathrm{E} . \\
25 \mathrm{E} . \\
18 \mathrm{E} . \\
19 \mathrm{E} . \\
20 \mathrm{E} . \\
21 \mathrm{E} . \\
24 \mathrm{E} . \\
25 \mathrm{E} . \\
18 \mathrm{E} . \\
19 \mathrm{E} . \\
20 \mathrm{E} . \\
21 \mathrm{E} . \\
23 \mathrm{E} . \\
24 \mathrm{E} . \\
25 \mathrm{E} .\end{array}$ & $\begin{array}{r}700 \\
9,280 \\
5,466 \\
11,780 \\
3,360 \\
3,260 \\
362 \\
13,050 \\
13,862 \\
7,680 \\
21,361 \\
15,573 \\
2,508 \\
14,900 \\
3,840 \\
12,456 \\
11,585 \\
14,645 \\
2,972 \\
2,218 \\
3,260 \\
300\end{array}$ & $\begin{array}{r}94 \\
67 \\
103 \\
77 \\
26 \\
34 \\
38 \\
64 \\
57 \\
22 \\
24 \\
34 \\
30 \\
50 \\
45 \\
18 \\
19 \\
23 \\
24 \\
26 \\
45 \\
36\end{array}$ & $\begin{array}{r}283.9 \\
202.3 \\
311.1 \\
232.5 \\
78.5 \\
102.7 \\
114.8 \\
193.3 \\
172.1 \\
66.4 \\
72.5 \\
102.7 \\
90.6 \\
151.0 \\
135.9 \\
54.4 \\
57.4 \\
69.5 \\
72.5 \\
78.5 \\
135.9 \\
108.7\end{array}$ & $\begin{array}{r}169.0 \\
120.4 \\
185.2 \\
138.4 \\
46.7 \\
61.1 \\
68.3 \\
115.0 \\
102.4 \\
39.5 \\
43.1 \\
61.1 \\
53.9 \\
89.9 \\
80.9 \\
32.4 \\
34.2 \\
41.4 \\
43.1 \\
46.7 \\
80.9 \\
64.7\end{array}$ & $\begin{array}{r}199 \\
1,877 \\
1,700 \\
2,739 \\
264 \\
335 \\
42 \\
2,523 \\
2,386 \\
510 \\
1,549 \\
1,599 \\
227 \\
2,250 \\
522 \\
678 \\
665 \\
1,018 \\
215 \\
174 \\
443 \\
33\end{array}$ & $\begin{array}{r}118 \\
1,117 \\
1,012 \\
1,630 \\
157 \\
199 \\
25 \\
1,501 \\
1,419 \\
303 \\
921 \\
951 \\
135 \\
1,339 \\
311 \\
404 \\
396 \\
606 \\
128 \\
104 \\
264 \\
19\end{array}$ \\
\hline $13 \mathrm{~S}$ & & 175,507 & $-\cdots---n_{-1}$ & $-\cdots-------$ & $-----1----$ & 22,119 & 13,160 \\
\hline
\end{tabular}

INFERRED POTENTIAL RESERVES

Colorado

\begin{tabular}{|c|c|c|c|c|c|c|c|}
\hline $\begin{array}{l}1 \mathrm{~N} . \\
1 \mathrm{~S} . \\
2 \mathrm{~S} . \\
3 \mathrm{~S} .\end{array}$ & $\begin{array}{l}103 \mathrm{~W} . \\
104 \mathrm{~W} . \\
104 \mathrm{~W} . \\
104 \mathrm{~W} . \\
104 \mathrm{~W} .\end{array}$ & $\begin{array}{r}10 \\
1,609 \\
680 \\
320 \\
45\end{array}$ & $\begin{array}{l}16 \\
20 \\
34 \\
27 \\
20\end{array}$ & $\begin{array}{r}48.3 \\
60.4 \\
102.7 \\
81.5 \\
60.4\end{array}$ & $\begin{array}{l}28.7 \\
35.9 \\
61.1 \\
48.5 \\
35.9\end{array}$ & $\begin{array}{r}(1) \\
97 \\
70 \\
26 \\
3\end{array}$ & $\begin{array}{r}(1) \\
58 \\
42 \\
15 \\
2\end{array}$ \\
\hline \multicolumn{8}{|c|}{ Utah } \\
\hline $\begin{array}{l}8 \mathrm{~S} . \\
9 \mathrm{~S} . \\
10 \mathrm{~S} . \\
11 \mathrm{~S} .\end{array}$ & $\begin{array}{l}25 \mathrm{E} . \\
24 \mathrm{E} . \\
25 \mathrm{E} . \\
24 \mathrm{E} . \\
18 \mathrm{E} . \\
19 \mathrm{E} . \\
20 \mathrm{E} . \\
21 \mathrm{E} . \\
24 \mathrm{E} . \\
25 \mathrm{E} . \\
20 \mathrm{E} . \\
21 \mathrm{E} . \\
22 \mathrm{E} . \\
23 \mathrm{E} . \\
24 \mathrm{E} . \\
20 \mathrm{E} . \\
21 \mathrm{E} . \\
22 \mathrm{E} . \\
23 \mathrm{E} . \\
24 \mathrm{E} . \\
25 \mathrm{E} . \\
21 \mathrm{E} . \\
22 \mathrm{E} .\end{array}$ & $\begin{array}{r}620 \\
12,150 \\
8,120 \\
3,552 \\
12,250 \\
15,730 \\
18,400 \\
6,400 \\
1,970 \\
2,044 \\
6,887 \\
13,282 \\
15,360 \\
17,030 \\
6,740 \\
3,330 \\
7,627 \\
18,780 \\
10,000 \\
2,870 \\
1,100 \\
2,030 \\
1,300\end{array}$ & $\begin{array}{r}18 \\
60 \\
35 \\
120 \\
30 \\
38 \\
42 \\
42 \\
60 \\
36 \\
37 \\
38 \\
44 \\
47 \\
50 \\
16 \\
24 \\
32 \\
39 \\
42 \\
30 \\
16 \\
17\end{array}$ & $\begin{array}{r}54.4 \\
181.2 \\
105.7 \\
362.4 \\
90.6 \\
114.8 \\
126.8 \\
126.8 \\
181.2 \\
108.7 \\
111.7 \\
114.8 \\
132.9 \\
141.9 \\
151.0 \\
48.3 \\
72.5 \\
96.6 \\
117.8 \\
126.8 \\
90.6 \\
48.3 \\
51.3\end{array}$ & $\begin{array}{r}32.4 \\
107.8 \\
62.9 \\
215.7 \\
53.9 \\
68.3 \\
75.5 \\
75.5 \\
107.8 \\
64.7 \\
66.5 \\
68.3 \\
79.1 \\
84.5 \\
89.9 \\
28.7 \\
43.1 \\
57.5 \\
70.1 \\
75.5 \\
53.9 \\
28.7 \\
30.5\end{array}$ & $\begin{array}{r}34 \\
2,202 \\
858 \\
1,287 \\
1,110 \\
1,806 \\
2,333 \\
812 \\
357 \\
222 \\
769 \\
1,525 \\
2,041 \\
2,417 \\
1,018 \\
161 \\
553 \\
1,814 \\
1,178 \\
364 \\
100 \\
98 \\
67\end{array}$ & $\begin{array}{r}20 \\
1,310 \\
511 \\
766 \\
660 \\
1,074 \\
1,389 \\
483 \\
212 \\
132 \\
458 \\
907 \\
1,215 \\
1,439 \\
606 \\
96 \\
329 \\
1,080 \\
701 \\
217 \\
59 \\
58 \\
40\end{array}$ \\
\hline $14 \mathrm{~S}$. & & 190,236 & $-\ldots$ & $-\ldots$ & $\ldots-$ & 23,322 & 13,879 \\
\hline
\end{tabular}


TABLE 3.-Estimated tonnage and potential oil yield of that part of the Mahogany zone and adjacent beds occurring in a continuous sequence at least 15 feet thick and yielding an average of 15 gallons oil per ton

[Estimates include the total tonnage and total potential oil yield of the deposit; no allowances were made for losses in mining or processing. Estimates include the rock containing potential reserves shown in tables 1 and 2 . Totals for indicated and inferred potential reserves given at the bottom of columns $3,7,81$

\begin{tabular}{|c|c|c|c|c|c|c|c|}
\hline \multicolumn{2}{|c|}{ Location } & \multirow{2}{*}{ Acreage } & \multirow{2}{*}{$\begin{array}{l}\text { Average thickness } \\
\text { of oil shale (feet) }\end{array}$} & \multirow{2}{*}{$\begin{array}{c}\text { Average tonnage } \\
\text { per acre of oil } \\
\text { shale (thousands of } \\
\text { tons) }\end{array}$} & \multirow{2}{*}{$\begin{array}{l}\text { A verage oil yield } \\
\text { per acre (thousands } \\
\text { of barrels) }\end{array}$} & \multirow{2}{*}{$\begin{array}{l}\text { Tonnage of oil } \\
\text { shale (millions of } \\
\text { tons) }\end{array}$} & \multirow{2}{*}{$\begin{array}{l}\text { Potential oil } \\
\text { yield (millions of } \\
\text { barrels) }\end{array}$} \\
\hline Townshlp & Range & & & & & & \\
\hline
\end{tabular}

INDiCated POTENTIAL RESERVES

Colorado

\begin{tabular}{|c|c|c|c|c|c|c|c|}
\hline $\begin{array}{l}1 \mathrm{~N} \\
1 \mathrm{~S}\end{array}$ & $\begin{array}{l}104 \mathrm{~W} \\
104 \mathrm{~W}\end{array}$ & $\begin{array}{l}899 \\
770\end{array}$ & $\begin{array}{l}200 \\
225\end{array}$ & $\begin{array}{l}648.0 \\
729.0\end{array}$ & $\begin{array}{l}231.4 \\
260.3\end{array}$ & $\begin{array}{l}583 \\
561\end{array}$ & $\begin{array}{l}208 \\
200\end{array}$ \\
\hline \multicolumn{8}{|c|}{ Utah } \\
\hline $\begin{array}{r}9 \mathrm{~s} . \\
10 \mathrm{~S} . \\
11 \mathrm{~S} . \\
12 \mathrm{~s} . \\
13 \mathrm{~s} .\end{array}$ & $\begin{array}{l}24 \mathrm{E} . \\
25 \mathrm{E} . \\
24 \mathrm{E} . \\
25 \mathrm{E} . \\
18 \mathrm{E} . \\
19 \mathrm{E} . \\
20 \mathrm{E} . \\
24 \mathrm{E} . \\
25 \mathrm{E} . \\
18 \mathrm{E} . \\
19 \mathrm{E} . \\
20 \mathrm{E} . \\
21 \mathrm{E} . \\
24 \mathrm{E} . \\
25 \mathrm{E} . \\
18 \mathrm{E} . \\
19 \mathrm{E} . \\
20 \mathrm{E} . \\
21 \mathrm{E} . \\
23 \mathrm{E} . \\
24 \mathrm{E} . \\
25 \mathrm{E} . \\
18 \mathrm{E} . \\
19 \mathrm{E} .\end{array}$ & $\begin{array}{r}700 \\
9,280 \\
5,466 \\
11,780 \\
3,360 \\
3,260 \\
362 \\
13,050 \\
13,862 \\
9,870 \\
22,811 \\
15,573 \\
2,508 \\
14,900 \\
3,840 \\
14,876 \\
20,369 \\
14,862 \\
2,972 \\
2,842 \\
4,263 \\
300 \\
4,100 \\
5,050\end{array}$ & $\begin{array}{r}290 \\
255 \\
320 \\
295 \\
60 \\
87 \\
99 \\
225 \\
215 \\
50 \\
59 \\
82 \\
74 \\
157 \\
95 \\
34 \\
40 \\
56 \\
58 \\
70 \\
120 \\
85 \\
22 \\
20\end{array}$ & $\begin{array}{r}939.6 \\
826.2 \\
1,036.8 \\
955.8 \\
194.4 \\
281.9 \\
320.8 \\
729.0 \\
696.6 \\
162.0 \\
191.2 \\
265.7 \\
239.8 \\
508.7 \\
307.8 \\
110.2 \\
129.6 \\
181.4 \\
187.9 \\
226.8 \\
388.8 \\
275.4 \\
71.3 \\
64.8\end{array}$ & $\begin{array}{r}335.5 \\
295.0 \\
370.4 \\
341.3 \\
69.4 \\
100.7 \\
114.6 \\
260.3 \\
248.8 \\
57.8 \\
68.3 \\
94.9 \\
85.6 \\
181.7 \\
109.9 \\
39.3 \\
46.3 \\
64.8 \\
67.1 \\
81.0 \\
138.8 \\
98.3 \\
25.5 \\
23.1\end{array}$ & $\begin{array}{r}658 \\
7,667 \\
5,667 \\
11,259 \\
653 \\
919 \\
116 \\
9,513 \\
9,656 \\
1,599 \\
4,361 \\
4,138 \\
601 \\
7,580 \\
1,182 \\
1,639 \\
2,640 \\
2,696 \\
558 \\
645 \\
1,657 \\
83 \\
292 \\
327\end{array}$ & $\begin{array}{r}235 \\
2,738 \\
2,025 \\
4,021 \\
233 \\
328 \\
41 \\
3,397 \\
3,449 \\
570 \\
1,558 \\
1,478 \\
215 \\
2,707 \\
422 \\
585 \\
943 \\
.963 \\
199 \\
230 \\
592 \\
29 \\
104 \\
117\end{array}$ \\
\hline & & 201,925 & - $-\cdots------$ & 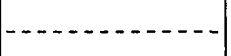 & - - - - - - - - - - - - & 77,250 & 27,587 \\
\hline \multicolumn{8}{|c|}{$\begin{array}{l}\text { INFERRED POTENTIAL RESERVES } \\
\text { Colorado }\end{array}$} \\
\hline $\begin{array}{ll}1 & \mathrm{~N} \\
2 & \mathrm{~N} \\
1 & \mathrm{~S} . \\
2 & \mathrm{~S} . \\
3 & \mathrm{~S} .\end{array}$ & $\begin{array}{l}103 \mathrm{~W} . \\
104 \mathrm{~W} . \\
103 \mathrm{~W} . \\
104 \mathrm{~W} . \\
104 \mathrm{~W} . \\
104 \mathrm{~W} . \\
104 \mathrm{~W} .\end{array}$ & $\begin{array}{r}2,798 \\
4,132 \\
1,740 \\
4,959 \\
680 \\
320 \\
45\end{array}$ & $\begin{array}{r}40 \\
125 \\
28 \\
45 \\
200 \\
60 \\
16\end{array}$ & $\begin{array}{r}129.6 \\
405.0 \\
90.7 \\
145.8 \\
648.0 \\
194.4 \\
51.8\end{array}$ & $\begin{array}{r}46.3 \\
144.6 \\
32.4 \\
52.1 \\
231.4 \\
69.4 \\
18.5\end{array}$ & $\begin{array}{r}363 \\
1,673 \\
158 \\
723 \\
441 \\
62 \\
2\end{array}$ & $\begin{array}{r}130 \\
597 \\
56 \\
258 \\
157 \\
22 \\
1\end{array}$ \\
\hline
\end{tabular}


TABLE 3.-Estimated tonnage and potential oil yield of that part of the Mahogany zone and adjacent beds occurring in a continuous sequence at least 15 feet thick and yielding an average of 15 gallons oil per ton-Continued

\begin{tabular}{|c|c|c|c|c|c|c|c|}
\hline \multicolumn{2}{|c|}{ Location } & \multirow{2}{*}{ Acreage } & \multirow{2}{*}{$\begin{array}{l}\text { A verage thickness } \\
\text { of oil shale (feet) }\end{array}$} & \multirow{2}{*}{$\begin{array}{c}\text { Average tonnage } \\
\text { per acre of oil } \\
\text { shale (thousands of } \\
\text { tons) }\end{array}$} & \multirow{2}{*}{$\begin{array}{l}\text { Average oil yield } \\
\text { per acre (thousands } \\
\text { of barrels) }\end{array}$} & \multirow{2}{*}{$\begin{array}{l}\text { Tonnage of oil } \\
\text { shale (millions of } \\
\text { tons) }\end{array}$} & \multirow{2}{*}{$\begin{array}{l}\text { Potential oil } \\
\text { yield (millions of } \\
\text { barrels) }\end{array}$} \\
\hline Township & Range & & & & & & \\
\hline \multicolumn{8}{|c|}{$\begin{array}{l}\text { INFERRED POTENTIAL RESERVES-Continued } \\
\text { Utah }\end{array}$} \\
\hline $\begin{array}{rr}8 & \text { S. } \\
9 & \mathrm{~S} . \\
10 & \mathrm{~S} . \\
11 & \mathrm{~S} . \\
& \\
& \\
12 & \mathrm{~S} . \\
& \\
& \\
13 \mathrm{~S} .\end{array}$ & $\begin{array}{ll}25 & \mathrm{E} . \\
24 & \mathrm{E} . \\
25 & \mathrm{E} . \\
24 & \mathrm{E} . \\
18 & \mathrm{E} . \\
19 & \mathrm{E} . \\
20 & \mathrm{E} . \\
21 & \mathrm{E} . \\
24 & \mathrm{E} . \\
25 & \mathrm{E} . \\
20 & \mathrm{E} . \\
21 & \mathrm{E} . \\
22 & \mathrm{E} . \\
23 & \mathrm{E} . \\
24 & \mathrm{E} . \\
17 & \mathrm{E} . \\
18 & \mathrm{E} . \\
20 & \mathrm{E} . \\
21 & \mathrm{E} . \\
22 & \mathrm{E} . \\
23 & \mathrm{E} . \\
24 & \mathrm{E} . \\
25 & \mathrm{E} . \\
17 & \mathrm{E} . \\
18 & \mathrm{E} . \\
19 & \mathrm{E} . \\
20 & \mathrm{E} . \\
21 & \mathrm{E} . \\
22 & \mathrm{E} . \\
21 & \mathrm{E} .\end{array}$ & $\begin{array}{r}3,480 \\
12,150 \\
8,120 \\
3,552 \\
12,250 \\
15,730 \\
18,400 \\
6,400 \\
1,970 \\
2,044 \\
6,887 \\
13,282 \\
15,360 \\
17,030 \\
6,740 \\
770 \\
4,220 \\
6,162 \\
7,627 \\
18,780 \\
10,500 \\
2,102 \\
1,100 \\
1,770 \\
6,235 \\
2,400 \\
11,310 \\
5,510 \\
2,450 \\
1,920\end{array}$ & $\begin{array}{r}130 \\
220 \\
175 \\
335 \\
70 \\
97 \\
108 \\
100 \\
210 \\
80 \\
93 \\
85 \\
91 \\
120 \\
168 \\
24 \\
27 \\
34 \\
50 \\
61 \\
85 \\
123 \\
37 \\
18 \\
18 \\
16 \\
22 \\
26 \\
34 \\
17\end{array}$ & $\begin{array}{r}421.2 \\
712.8 \\
567.0 \\
1,085.4 \\
226.8 \\
314.3 \\
349.9 \\
324.0 \\
680.4 \\
259.2 \\
301.3 \\
275.4 \\
294.8 \\
388.8 \\
544.3 \\
77.8 \\
87.5 \\
110.2 \\
162.0 \\
197.6 \\
275.4 \\
398.5 \\
119.9 \\
58.3 \\
58.3 \\
51.8 \\
71.3 \\
84.2 \\
110.2 \\
55.1\end{array}$ & $\begin{array}{r}150.4 \\
254.5 \\
202.5 \\
387.6 \\
81.0 \\
112.2 \\
124.9 \\
115.7 \\
243.0 \\
92.6 \\
107.6 \\
98.3 \\
105.3 \\
138.8 \\
194.4 \\
27.8 \\
31.2 \\
39.3 \\
57.8 \\
70.6 \\
98.3 \\
142.3 \\
42.8 \\
20.8 \\
20.8 \\
18.5 \\
25.5 \\
30.1 \\
39.3 \\
19.7\end{array}$ & $\begin{array}{r}1,466 \\
8,661 \\
4,604 \\
3,855 \\
2,778 \\
4,944 \\
6,438 \\
2,074 \\
1,340 \\
530 \\
2,075 \\
3,658 \\
4,528 \\
6,621 \\
3,669 \\
60 \\
369 \\
679 \\
1,236 \\
3,711 \\
2,892 \\
838 \\
132 \\
103 \\
363 \\
124 \\
806 \\
464 \\
270 \\
106\end{array}$ & $\begin{array}{r}523 \\
3,092 \\
1,644 \\
1,377 \\
992 \\
1,765 \\
2,298 \\
740 \\
479 \\
189 \\
741 \\
1,306 \\
1,617 \\
2,364 \\
1,310 \\
21 \\
132 \\
242 \\
441 \\
1,326 \\
1,032 \\
299 \\
47 \\
37 \\
130 \\
44 \\
288 \\
166 \\
96 \\
38\end{array}$ \\
\hline & & 240,925 & 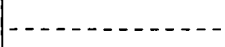 & $\mid-\cdots----\cdots$ & 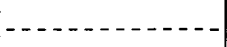 & 72,816 & 25,997 \\
\hline
\end{tabular}

The estimates are based on assays of approximately 150 sets of subsurface samples and approximately 25 sets of surface samples. The descriptions of the subsurface sample localities and their assay data were published by the U.S. Bureau of Mines (Stanfield, Rose, and others, 1954; Stanfield and others, 1964). Forty of the subsurface sample sets are from core holes, only one of which is outside the mapped area. Virtually all the estimated resources not in the report area are classed as inferred because control points are sparse in the western part of the basin, and because there are no core assay data to substantiate the cutting assays. Also, the assays of cuttings from several wells in the east-central part of the basin indicated anomalous thicknesses of oil shale. A small amount of additional indicated potential reserves lies adjacent to the northeastern part of the mapped area.

Owing to inconclusive assay data, estimates were made only for shale averaging 15 gallons oil per ton. The thickness map for shale of this grade in the Uinta Basin is shown in figure 8. The Uinta Basin contains an estimated 31 billion barrels of oil as indicated potential reserves and about 290 billion barrels of oil as inferred potential reserves in the shale yielding an average of 15 gallons of oil per ton. These reserves are in a sequence that has a minimum thickness of 15 feet and a maximum thickness of presumably more than 700 feet.

\section{GILSONITE}

\section{DESCRIPTION AND GEOLOGIC SETTING}

Gilsonite (classed as an asphaltite) is the residue of natural petroleum. The mineral was first described by Blake (1885), who named it "uintahite." It is commonly called gilsonite, however, for Samuel H. Gilson, who was first to encourage the mining of this solid hydrocarbon. Gilsonite is a black homogeneous tarry-appearing substance having a hardness of about 2 . It is very brittle and commonly has a conchoidal fracture. On fresh surfaces this asphaltite has a brilliant luster, but on weathered surfaces the asphaltite is dull black or brown. The physical and chemical characteristics of gilsonite were described by Abraham (1945, p. 250-253). 


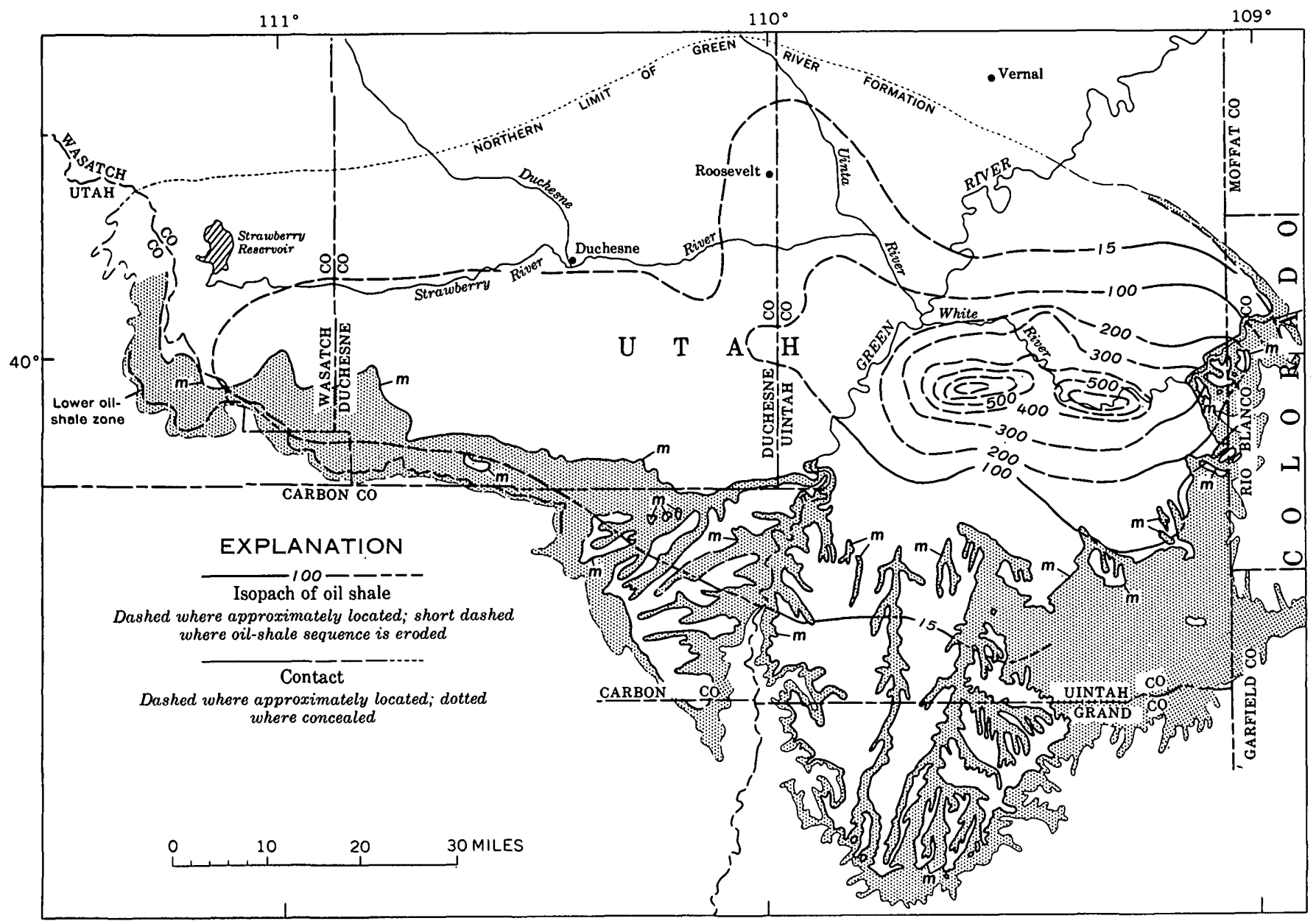

Frgure 8.-Thickness, in feet, of ofl-shale beds of the Green River Formation, Uinta Basin area, thlat will yield an average of 15 gallons of oil per ton. Thickness interval is 100 feet with 15-foot cutoff. Stippled pattern shows outcrop area of the part of the Green River Formation underlying the Mahogany bed (m). Outcrop area west of the Green River modified from Bradley (1931, pl. 1).

For marketing purposes gilsonite is classified as "selects" or as "standards," in accordance with its melting point. The select ore melts at temperatures between $250^{\circ}$ and $300^{\circ} \mathrm{F}$, and standard ore melts at temperatures between $300^{\circ}$ and $500^{\circ} \mathrm{F}$.

Gilsonite occurs as long narrow vein deposits between the walls of northwest-trending nearly vertical joints. Veins in the mapped area are about 0.5-7 miles long and a fow inches to about 18 feet wide. Widths measured along the veins are shown in figure 9 . The maximum vertical extent is estimated to be about 1,400 feet. The veins are almost parallel, and the average strike is approximately $\mathrm{N} .60^{\circ} \mathrm{W}$. Only one northeast-trending vein was seen; it has a maximum width of 12 inches and can be traced laterally about 200 feet southwest from its intersection with the Little Bonanza vein, just outside the mapped area. Most of the veins lie along two north west-plunging structural noses. The trace of each vein is remarkably straight, and even the longest veins in the mapped area deviate only a few hundred feet from a straight line. Walls of the veins are smooth and show little irregularity (fig. 10A); however, small faults have horizontally offset the veins. Each offset noted is less than the width of the vein displaced.

In the mapped area gilsonite veins occur in the Wasatch, Green River, and Uinta Formations. Northwest of the mapped area veins also occur in the Duchesne River Formation. The widest and longest veins occur mainly in the Uinta Formation. These veins are widest in the massive sandstone beds in the basal part of the Uinta Formation and thin upward in the shale and sandstone in the middle part of the Uinta Formation. They also thin downward in the marlstone in the Green River Formation and pinch out above the Mahogany bed. Veins below the Mahogany bed are thickest in sandstone beds of the Douglas Creek Member of the Green River Formation and Renegade Tongue of the Wasatch Formation and thin downward in the shale 
EXPLANATION

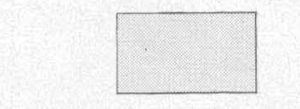

Area underlain by Mahogany oil-shale bed

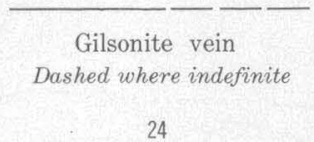

Width of vein, in inches, measured by author

\section{9}

Width of vein, in inches, measured by Eldridge (1901)

67

Combined widths, in inches of two or more veins

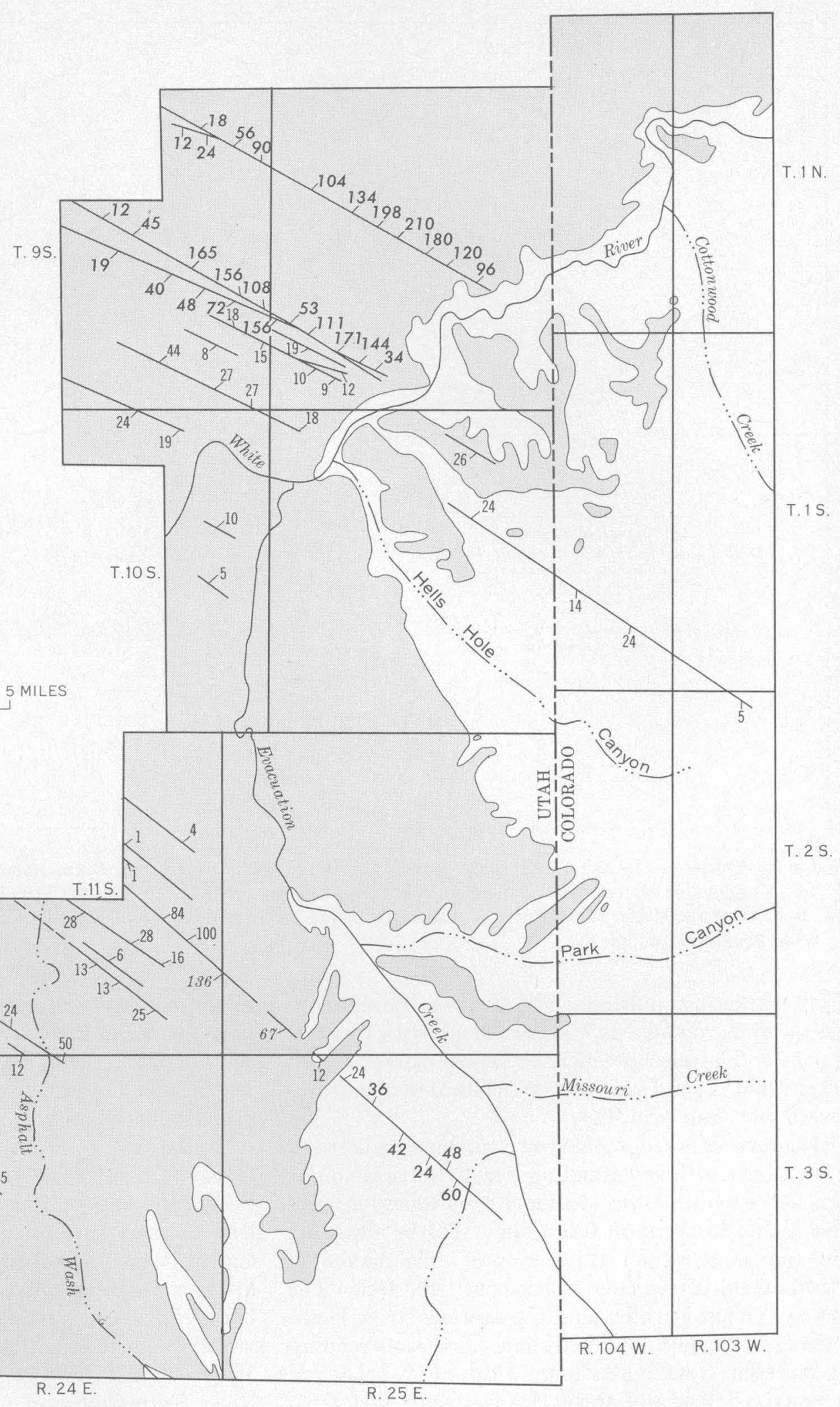

FTGURE 9.-Location and width of gilsonite veins. 


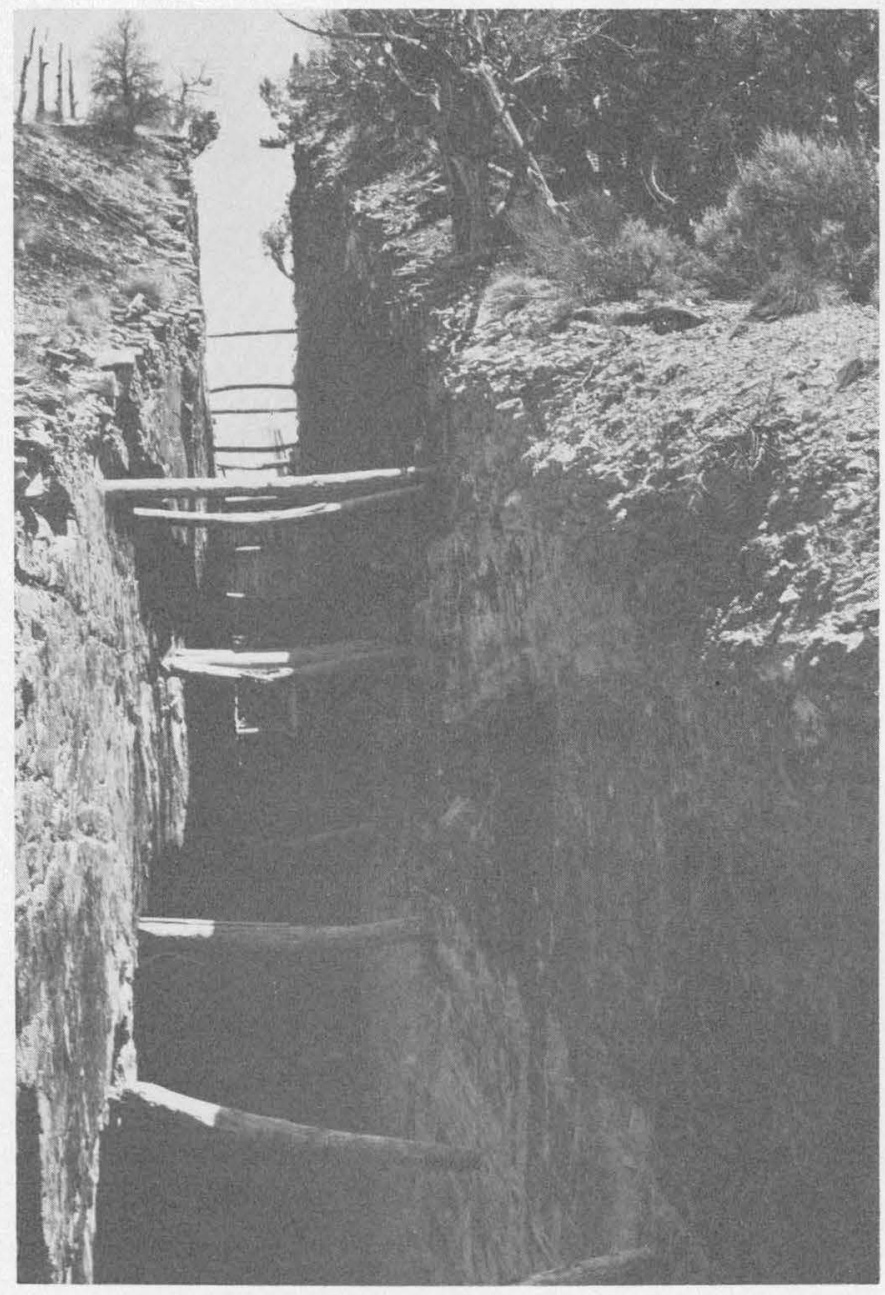

$A$

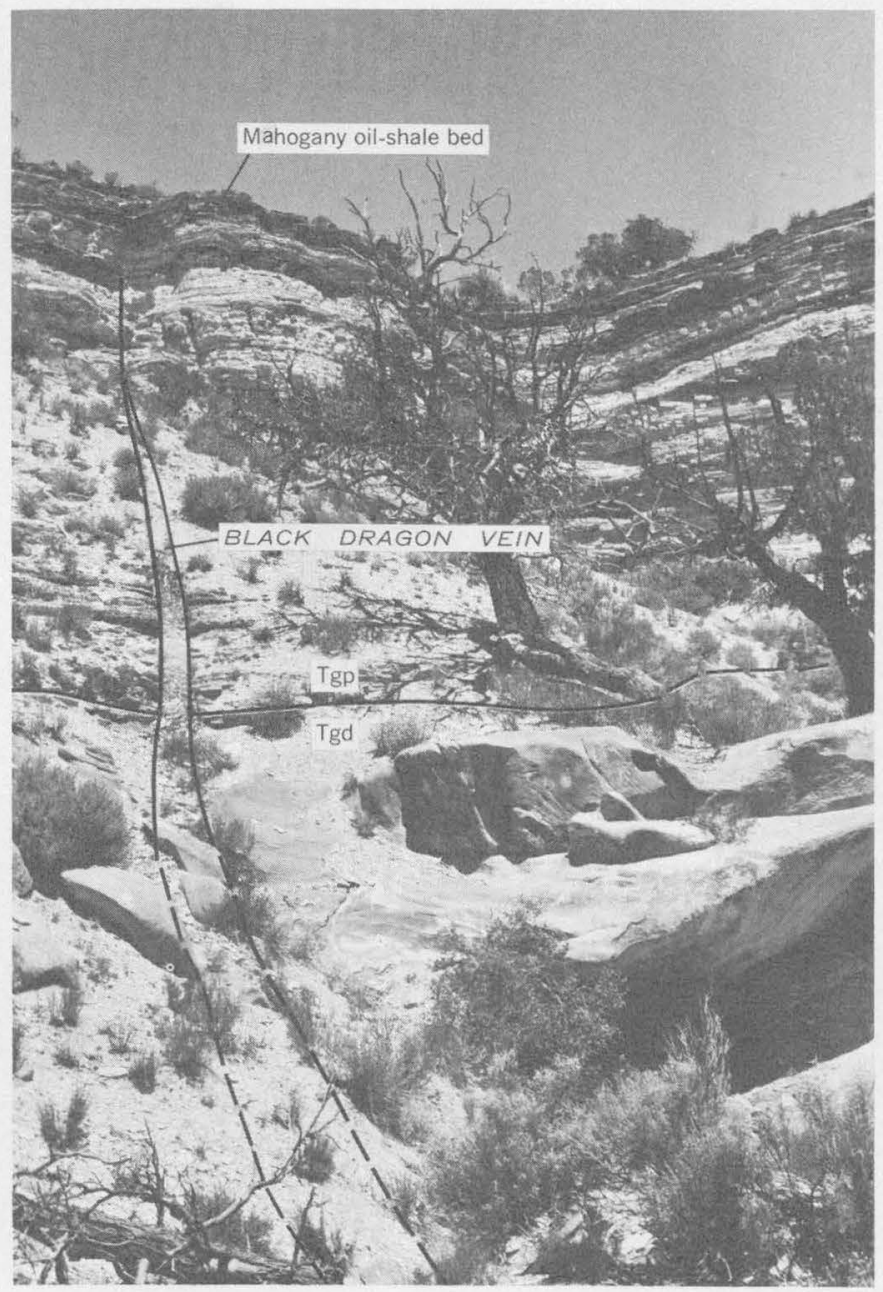

$B$

Figure 10.-Gilsonite veins. $A$, Mined-out vein near Rainbow, Utah, NE1/4 sec. 23 , T. 11 S., R. 24 E. Vein is about 7 feet wide. Note pole stulls that have been buckled by compression. B, Black Dragon vein in NW1/4 sec. 4 , T. 12 S., R. 25 E. Vein pinches out near base of Mahogany oil-shale bed. Tgp, Parachute Creek Member; Tgd, Douglas Creek Member.

and sandstone in the lower part of the Green River Formation and in the upper part of the Wasatch. These veins thin upward in the marlstone of the Green River Formation and pinch out below the Mahogany bed (fig. $10 B$ ). The forces that fractured and separated the sandstone beds produced only flowage or bedding-plane slippage in the Mahogany bed, and the veins therefore do not cut this bed. Where the veins cut marlstone adjacent to the Mahogany bed, they commonly split into several veins or veinlets that pinch out upward or downward toward the Mahogany bed. The width attained by a vein in the sandstone sequence generally is directly proportional to the thickness of the marlstone sequence cut by the vein. The absence of a thick sandstone sequence in the Green River Formation below the Mahogany bed in the area northeast of Hells Hole Canyon is probably the reason that the Independent and Cowboy veins have no wide counterparts below the Mahogany bed.

The gilsonite veins are homogeneous and contain very little foreign matter. The foreign matter present consists of sparse chunks of wallrock. Vugs containing water are sometimes found in mining (Charles Neal, oral commun., 1959). Plastic gilsonite has been reported in some of the deeper mines. Evidently this is petroleum that, because of its deep burial, has not lost all its lighter fractions. Impregnation of the wallrock by gilsonite is common where the wallrock is sandstone. Gilsonite has permeated these beds over distances ranging from a fraction of an inch to several feet. No impregnation of the marlstone was noted. The gilsonite in some veins has a "pencillate" structure near the wall of the vein. This fine columnar structure, perpendicular to the walls of veins and extending inward from the 
walls for a few inches, may have been caused by compression due to readjustment of the walls of the joints. Other indications of compression are buckled stulls (fig. $10 \mathrm{~A}$ ) and small pieces of gilsonite that burst or pop from the working face during mining.

\section{MAJOR VEINS}

Cowboy vein.-The Cowboy vein is the widest gilsonite vein in the Uinta Basin. The maximum width, measured by Eldridge (1901), is $171 / 2$ feet. Total length of the outcrop of the Cowboy vein is about 10 miles, 7 miles of which is within the mapped area. Estimated maximum vertical extent of the Cowboy vein in the mapped area is 1,000 feet. In outcrop the vein trends N. $60^{\circ}-63^{\circ} \mathrm{W}$. The Cowboy vein is widest in a massive sandstone in the lower part of the Uinta Formation. Outcrops indicate that the vein pinches out stratigraphically downward in marlstone and oil shale about 150 feet above the Mahogany bed, and pinches out upward in a predominantly thin-bedded sequence in the Uinta Formation.

The Eureka mine, operated (1964) by the American Gilsonite Co., is mined along the widest part of the Cowboy vein (about 31/2 miles northeast of Bonanza) and is at least 800 feet deep (Kretchman, 1957, p. 72 73). Gilsonite from the Eureka mine is carried by a slurry pipeline to a refinery at Gilsonite, Colo., which is about 14 miles northwest of Grand Junction.

Independent-Tabor vein.-The Independent vein and the Tabor vein are actually one vein, but the parts northwest and southeast of the junction with the Little Bonanza vein are separately named. The Independent vein, also called the Bonanza vein, is northwest of the junction, and the Tabor vein is to the southeast. Total length of outcrop of the Independent-Tabor vein is about $71 / 2$ miles, 7 miles of which is within the mapped area. The maximum width, measured by Eldridge (1901), is approximately 14 feet. The estimated maximum vertical extent in the mapped area is 1,100 feet. In outcrop the vein trends $\mathrm{N}$. $55^{\circ}-62^{\circ} \mathrm{W}$. The vein is widest in a predominantly massive sandstone sequence in the lower part of the Uinta Formation. It pinches out stratigraphically downward in marlstone above the Mahogany bed in the Parachute Creek Member of the Green River Formation and pinches out upward in shale and sandstone in the Uinta Formation.

Little Bonanza vein.-The outcrop of the Little Bonanza vein is approximately 5 miles long, virtually all of which lies within the mapped area. The maximum width, measured by Eldridge (1901), is 13 feet. Estimated maximum vertical extent of the vein in the mapped area is 1,200 feet. The outcrop trends N. $68^{\circ}$ W. The Little Bonanza vein is widest in a predominantly massive sandstone sequence in the Uinta Forma- tion. The vein outcrop pinches out stratigraphically upward in shale and sandstone in the Uinta Formation, and downward presumably in thin-bedded marlstone in the Parachute Creek Member of the Green River Formation and above the Mahogany oil-shale bed.

The American Gilsonite Co. is mining (1964) the Little Bonanza vein southeast of Bonanza, Utah. The ore is hauled by truck to the railroad at either Rifle or Craig, Colo.

Wagonhound vein.-The total length of the outcrop of the Wagonhound vein is about $41 / 2$ miles, all of which is within the mapped area. The maximum width measured by the author is about $31 / 2$ feet. The estimated vertical extent of the Wagonhound vein is 1,300 feet. In outcrop this vein trends N. $65^{\circ}$ W. The Wagonhound vein is thickest in sandstone of the Uinta Formation. The outcrop pinches out stratigraphically upward in the Uinta Formation, and downward in marlstone of the Evacuation Creek Member of the Green River Formation.

Weaver-Colorado vein.-The total length of outcrop of the Weaver-Colorado vein is $61 / 2$ miles, all of which lies within the mapped area. The name "Weaver" is applied to the Utah part of the vein, and "Colorado," to the Colorado part. 'The maximum width measured by the author is 2 feet, and the estimated vertical extent is 1,400 feet. The outcrop, which lies approximately on a projection of the outcrop of the Wagonhound vein, trends N. $58^{\circ} \mathrm{W}$. The Weaver-Colorado vein is widest in massive sandstone and limestone in the Douglas Creek Member of the Green River Formation. The outcrop of the vein pinches out stratigraphically upward in marlstone of the Parachute Creek Member of the Green River Formation and pinches out downward in shale in the Wasatch Formation.

Little Emma (Uinta) vein.-The outcrop of the Little Emma (Uinta) vein is about $41 / 2$ miles long, $21 / 2$ miles of which lies within the mapped area. The maximum width of the vein is about 3 feet (Charles Neal, oral commun., 1959). The estimated vertical extent is 1,000 feet. The outcrop of the vein trends N. $67^{\circ} \mathrm{W}$. Maximum width of the vein is in sandistone of the Uinta Formation. The vein pinches out stratigraphically upward and downward in the Uinta Formation.

Rainbow vein.-The Rainbow vein, whose outcrop is about $41 / 2$ miles long, lies almost entirely within the mapped area. The northwestward extension of the Rainbow vein is called the Pride-of-the-West vein. The dividing line between these two parts of the vein is just west of the western boundary of the mapped area. The maximum width of the Rainbow vein, where it lies in a single fracture, is approximately 8 feet. In the rocks that are about 200 feet above and 200 feet below the 
Uinta-Green River contact, the Rainbow system consists of from two to six veins. At one locality six veins have a combined width of approximately 11 feet, and maximum width of any vein in this group is approximately 3 feet. The estimated maximum vertical extent of the Rainbow vein is 600 feet. The outcrop of the Rainbow vein trends $N$. $48^{\circ}-58^{\circ} \mathrm{W}$. The vein is widest in the massive sandstone of the lower part of the Uinta Formation. The outcrop of the vein pinches out stratigraphically downward above the Mahogany bed in marlstone of the Parachute Creek Member of the Green River Formation and thins stratigraphically upward in the Uinta Formation.

For many years, during the operation of the Uintah Railway, the Rainbow vein supplied a large percentage of all the high-grade gilsonite produced. The vein was mined to a depth of about 400 feet (Charles Neal, oral commun., 1959). Small-scale mining was conducted sporadically alnng the Rainbow vein during 1940-55.

Black Dragon vein.-The Black Dragon vein crops out for a distance of about 5 miles. The entire outcrop is within the mapped area. The maximum width, measured by Eldridge (1901), is 5 feet, and the estimated maximum vertical extent is 1,100 feet. The Black Dragon vein trends N. $48^{\circ} \mathrm{W}$. and lies a few hundred feet northeast of the projected Rainbow vein. The vein is widest in massive sandstone beds of the Douglas Creek Member of the Green River Formation and of the Renegade Tongue of the Wasatch Formation. It pinches out stratigraphically downward in shale of the Douglas Creek Member and pinches out upward just below the Mahogany bed in oil-shale beds of the Parachute Creek Member. Outcrops of the northwest end of the Black Dragon vein and of the southeast end of the Rainbow vein are about half a mile apart; the two veins are apparently separated by approximately 150 feet of stratigraphic section. The author believes that the Black Dragon vein extends northwestward beneath the Rainbow vein (fig. 11). The northwest extent of the Black Dragon vein is probably limited by the extent of the massive sandistone in the Douglas Creek Member.

The Black Dragon vein has yielded much select gilsonite and has been mined to a depth of 700 feet (Charles Neal, oral commun., 1959). Very little mining has been done along the Black Dragon vein since 1940.

\section{ORIGIN}

Gilsonite is residue of a petroleum that flowed into fractures from a source not definitely known. After moving into the fractures, most of the hydrocarbon solidified. Proposed theories concerning the origin of the petroleum and an appraisal of each are as follows:

1. The petroleum came from an overlying asphalt lake or overlying reservoir beds. The geometry of the fractures containing gilsonite and the absence of any indication of a preexisting asphalt lake or overlying source bed's virtually preclude this theory.

2. The petroleum came from reservoirs in pre-Tertiary rocks. This theory is proposed chiefly because of the large reserves of hydrocarbons in pre-Tertiary beds in nearby fields. Stratigraphically, outcrops of gilsonite occur no lower than the upper part of the Wasatch Formation; however, gilsonite was reportedly found during exploratory drilling in Cretaceous rocks in the eastern part of the Uinta Basin. Some geologists suggest that the Weber Sandstone of Permian and Pennsylvanian age-a prolific oil producer in the Rangely and Ashley Valley fields-is a possible source for the gilsonite. But the rocks between the base of the Green River Formation and the top of the Weber Sandstone near Bonanza are approximately 9,500 feet thick. Also, the trace-element suite in gilsonite is similar to the trace-element suites in crude oils and asphalt seeps from the Wasatch and Green River Formations, but it is not similar to the trace-element suite in crude oil from the Weber Sandstone (Erickson and others, 1954, table 3; Bell, 1960, tables 2,3).

3. The petroleum came from reservoirs in the upper part of the Wasatch Formation and the lower part of the Green River Formation. High-pour-point oil is being produced from the upper part of the Wasatch Formation and the lower part of the Green River Formation in fields in the Uinta Basin. Fractures containing gilsonite are found in outcrops of the upper part of the Wasatch and lower part of the Green River Formations; beneath the surface such fractures may penetrate reservoir beds that could have furnished a large volume of petroleum to the void spaces. The association of the veins with structural noses also supports this theory. The position of the large veins above the unfractured Mahogany bed, however, requires circuitous movement of the oil from reservoirs in the basal Green River or upper Wasatch. The petroleum could move upward only in some marginal part of the basin where the Mahogany bed was not deposited or where there is an unconformity, and then move laterally to its present position.

4. The petroleum is a result of the metamorphosis of kerogenaceous material in the marlstones and oil shales adjacent to the veins. Most, and possibly all, of the veins are, at least in part, adjacent to beds of the Green River Formation that contain 
organic matter. Because of the vast amount of organic matter in the Green River Formation, metamorphosis of only a small part of it would form enough petroleum to fill the gilsonite veins. Hunt, Stewart, and Dickey (1954), in a study of hydrocarbons of the Uinta Basin, compared several chemical and physical properties of free hydrocarbons with those of hydrocarbons extracted from adjacent beds of the Wasatch, Green River, and Uinta Formations. From these comparisons they (1954, p. 1683-1690) concluded that each type of free hydrocarbon, such as wurtzilite or ozocerite, was derived from the organic matter in a particular stratigraphic unit adjacent to the free hydrocarbon occurrence, and that the probable source of gilsonite was the oil shale in the middle and upper parts of the Green River Formation from which shale oil moved directly into the veins.

5. The petroleum came from sandstone beds adjacent to the widest part of the vein. All veins of appreciable size are associated with thick sequences of sandstone. These veins cut across the sandstone beds, reach their maximum width in sandstone, become progressively narrower, and finally pinch out, in the finer grained sediments above and below the sandstone beds. Perhaps oil and gas derived from organic matter in the sediments migrated with connate water into the sandstone shortly after deposition, and the remaining organic matter later formed kerogen. Later, fractures formed and became filled with fluids from the sandstone reservoir. Two facts are in disagreement with this interpretation. The sandstone of the Uinta Formation contains no gilsonite or evidence of petroleum residue except for minor and erratic impregnation immediately adjacent to the gilsonite veins, and the veins are not apparently connected with the widespread impregnated sandstone beds in the Douglas Creek Member. Also, the gilsonite seems to have been highly viscous when it was emplaced, and no obvious mechanism for the nearly complete removal of viscous hydrocarbon from the main body of sandstone has been observed or proposed.

\section{Conclusions}

The present study did not produce sufficient data to establish details of the origin of gilsonite veins. However, certain conclusions based on field evidence seem significant. The gilsonite-forming hydrocarbons were evidently viscous fluids emplaced during a relatively short period of time, this rapid accumulation suggesting that their source was a large highly permeable reservoir or reservoirs. All major veins are widest in thick sandstone and pinch out stratigraphically upward and down- ward in finer grained rock; this variation indicates a greater fluid pressure in the sandstone, or less resistance to opening of fractures in the sandstone, than in the finer grained rock. Fracturing of the rocks occurred after their complete lithification and when the oil shale probably had little permeability.

If the indurated oil shale is assumed to be permeable enough to allow its fluids to move into veins, the shale adjacent to a vein should be depleted or enriched, depending on the amount of permeability, in some hydrocarbon fractions and should be leaner or richer than the same shale farther from the vein. Field examinations have not revealed diminution or increase in the potential oil yield of oil-shale beds near gilsonite veins. Any major movement of fluids out of the organic-rich sediments, therefore, probably was directed toward more permeable beds and occurred prior to lithification.

Sandstone best fits the description of the assumed reservoir. The sandstones cropping out adjacent to the widest parts of the veins are not considered to be likely sources, however, because most of these sandstones contain little or no petroleum residue. Accordingly, attention was focused on the sandstones in the Green River Formation that produce asphaltic oil in fields downdip from the gilsonite veins. The fields are in an area between the structural axis on the north and the depositional axis (during Green River time) on the south. Oil production is from beds that were deposited in a near-shore environment that received abundant detrital material from the direction of the Uinta Mountains and lay adjacent to a lake environment that was rich in organic matter. Fluids from the organic-rich lacustrine sediments are postulated to have moved into the porous sediments a short time after deposition. The sediments were later lithified and folded, and the fluids became trapped in updip pinchouts of the coarser sediments. The coarser rocks were susceptible to extensive vertical fracturing that allowed widespread vertical and horizontal movement of fluid hydrocarbons from any breached reservoir; the fracturing and circulation thus produced the gilsonite veins. The inspissation of the fluids took place as erosion progressed and is still taking place in deeply buried veins.

\section{DEVETOPMENT}

Mining and marketing of gilsonite began about 1888 and have increased through the years as the mining and transportation methods have been improved and the number of uses of the mineral has been increased. The first mines were in the north-central part of the Uinta Basin, outside the mapped area. About 1900 the center of operations moved into the southeastern part of the basin because the largest veins were located 
there. Several mines were opened along the Rainbow and Black Dragon veins and nearby veins. From 1900 to 1935 these mines produced a large percentage of the total gilsonite marketed throughout the world. During this time the mining camps of Rainbow, Dragon, and Watson were established. About 1935 these camps were abandoned except for sporadic inhabitance, and most of the mining operations were moved north of the White River to the area around Bonanza. Virtually all gilsonite mined in the world comes from the Uinta Basin, and the Cowboy and Little Bonanza veins produce a large percentage of this ore.

For many years all gilsonite was mined by use of pick and shovel, and some is still produced by this method. The narrowness of many veins prohibits mechanization, and blasting is hazardous because of the explosive nature of gilsonite dust. Several disastrous fires have resulted from explosions set off by spark or open flame. Gilsonite dust also interferes with mechanization of mining because the dust clogs some types of equipment. Much recent research in gilsonite technology has been directed toward finding a method for mining gilsonite by means of rotary drill powered by water under high pressure. Since 1957 the American Gilsonite Co. has successfully used several new mining methods, among which are the use of a tunnel-boring machine and a large-hole rig. These new methods of mining were described by Kilborn (1964).

Transportation of gilsonite from mine to market has advanced through several stages. The first gilsonite shipped out of the Uinta Basin was moved by wagon to the railroad at Price, Utah; the wagon was the chief means of transportation until a railroad was constructed in the Uinta Basin. In 1904 the Uintah Railway was completed between Dragon, Utah and Mack, Colo. (about 20 miles northwest of Grand Junction), where it joined with the Denver and Rio Grande Western Railroad. Later the railway was extended to Watson, Utah, and Rainbow, Utah. This unusual narrow-gage line featured $71 / 2$ percent grades and $76^{\circ}$ curves (Kretchman, 1957, p. 40, 44). The Uintah Railway was abandoned in 1937 because the truck had become the principal hauler of gilsonite. Although trucks are still used for transportation of gilsonite, another method is also used. Gilsonite is carried a distance of 72 miles by means of a 6 -inch diameter slurry pipeline from the Cowboy vein to a refinery at Gilsonite, Colo. (Kretchman, 1957).

Gilsonite is used in numerous ways. At present a major part of the gilsonite mined is supplied to the refinery at Gilsonite, Colo., where it is converted to metallurgical coke and gasoline. Gilsonite is also used in the manufacture of floor tile, inks, paints, electrical insulations, brake linings, caulking materials, battery boxes, some types of fiberboard, and insulation for underground steam and hot-water pipes (Kretchman, 1957, p. 61).

\section{RESERVES}

The original gilsonite reserves of all veins in the area were estimated by the author through the use of available surface and subsurface data. The estimates given in table 4 are for total reserves in place and are not adjusted for gilsonite that has already been mined or for gilsonite that may not be mined in the future because of limitations of vein width or other factors. Little is known about the complete extent and configuration of the veins underground; hence, several assumptions based on surface observations were used in the estimation of reserves. These assumptions are (1) the widths of the veins change uniformly between points of measurement, (2) the widths are constant downdip from points of measurement to a line directly below the northwesternmost outcrop of the vein or to the boundary of the area, and (3) the base of each vein occurs along the base of the lowermost bed in which the vein crops out or along the base of the lowermost bed where gilsonite has been mined, depending on which bed is lowermost in the stratigraphic sequence. Longitudinal sections were drawn for all veins in the area for aid in calculation of reserves. Four of these sections are shown in figure 11. Data on all the longitudinal sections and the information shown in figure 9 , as well as other field observations were used in the estimation of the original gilsonite reserves.

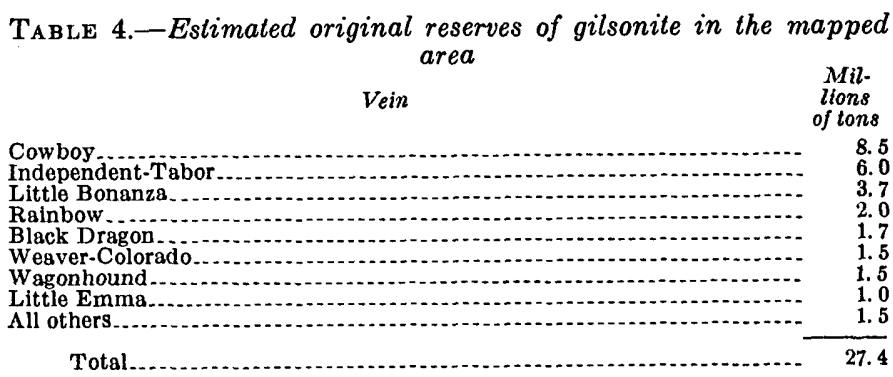

The 27.4 million tons of gilsonite estimated as the original reserve for the mapped area is a large part of the total estimated reserve of the Uinta Basin. The original reserve of the basin is estimated to have been about 45 million tons; probably about one-tenth of this amount has been mined (Cashion, 1964, p. 65).

\section{BITUMINOUS SANDSTONES}

Sandstones impregnated with bituminous material occur in the uppermost part of the Douglas Creek Member and in the lowermost part of the Parachute Creek Member in the southeastern and south-central parts of 

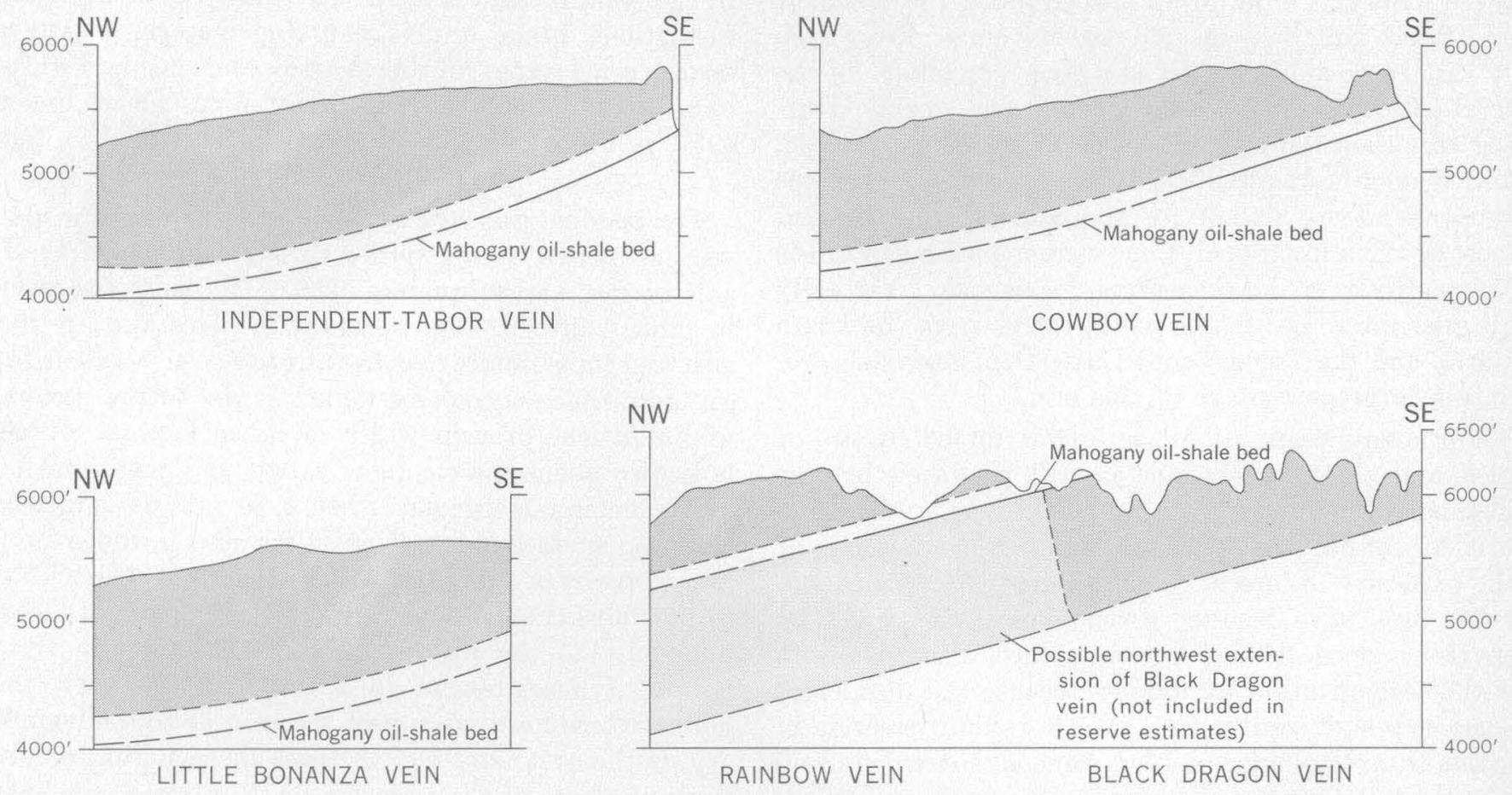

0

5 MILES

Frgure 11.-Longitudinal sections of gilsonite veins. Vertical exaggeration, $\times 8$.

the mapped area. Impregnated sandstones and conglomerates occur in the Douglas Creek Member along Raven Ridge north of the mapped area; however, none were found along the part of Raven Ridge which lies within the mapped area. The bituminous sandstones in the southern part of the area are in a stratigraphic sequence $10-350$ feet thick. The sequence contains from one to four bituminous beds that are 5-120 feet thick. Analyzed oil yields of the sandstones range from a trace to 23 gallons per ton. The thickest, most continuously impregnated bed or beds occurs in the Douglas Creek Member in a zone about 100 feet below the Mahogany oil-shale bed. The outcrop of this zone is shown in figure 12. Impregnation of beds below and above this zone, especially those beds in the Parachute Creek Member, is neither as great nor as widespread as within the zone. West of the area shown in figure 12, the zone contains sandstones which are locally impregnated. In most of the area northeast of Bitter Creek, as shown in figure 12, only one impregnated sandstone is present in the sequence. This bed, which lies within the zone just deseribed, is at the top of the Douglas Creek Member, about 90 feet below the Mahogany bed. Two to four impregnated sandstone beds are present in the sequence throughout most of the area southwest of Bitter Creek. Of these, the uppermost bed is about 30 feet strati- graphically above the Mahogany bed, but the beds containing the most bitumen are about 100 feet stratigraphically below the Mahogany bed.

The thickest and most highly impregnated sandstones occur in an area near the Uintah County-Grand County boundary a few miles southwest of Sweetwater Canyon. The sandstones in this area were mapped and evaluated by Whittier and Becker (1962).

The degree of bitumen impregnation of the sandstones varies both laterally and vertically. Vertically, all degrees of impregnation are visible in a sandstone bed at any one locality. Horizontally, a variation from slightly impregnated sandstone to highly impregnated sandstone may occur within a distance of a few hundred feet along the outcrop. In the area around P. R. Springs, however, the variation is less abrupt and of a lesser degree.

The highly impregnated beds are very dark gray and are cemented by the tarry bituminous material. On very warm days bitumen oozes from some beds. The slightly impregnated beds are speckled gray, and the specks of bitumen can easily be mistaken for carbonaceous material unless a sample is heated or is treated with a petroleum solvent to determine whether it is bitumen. 


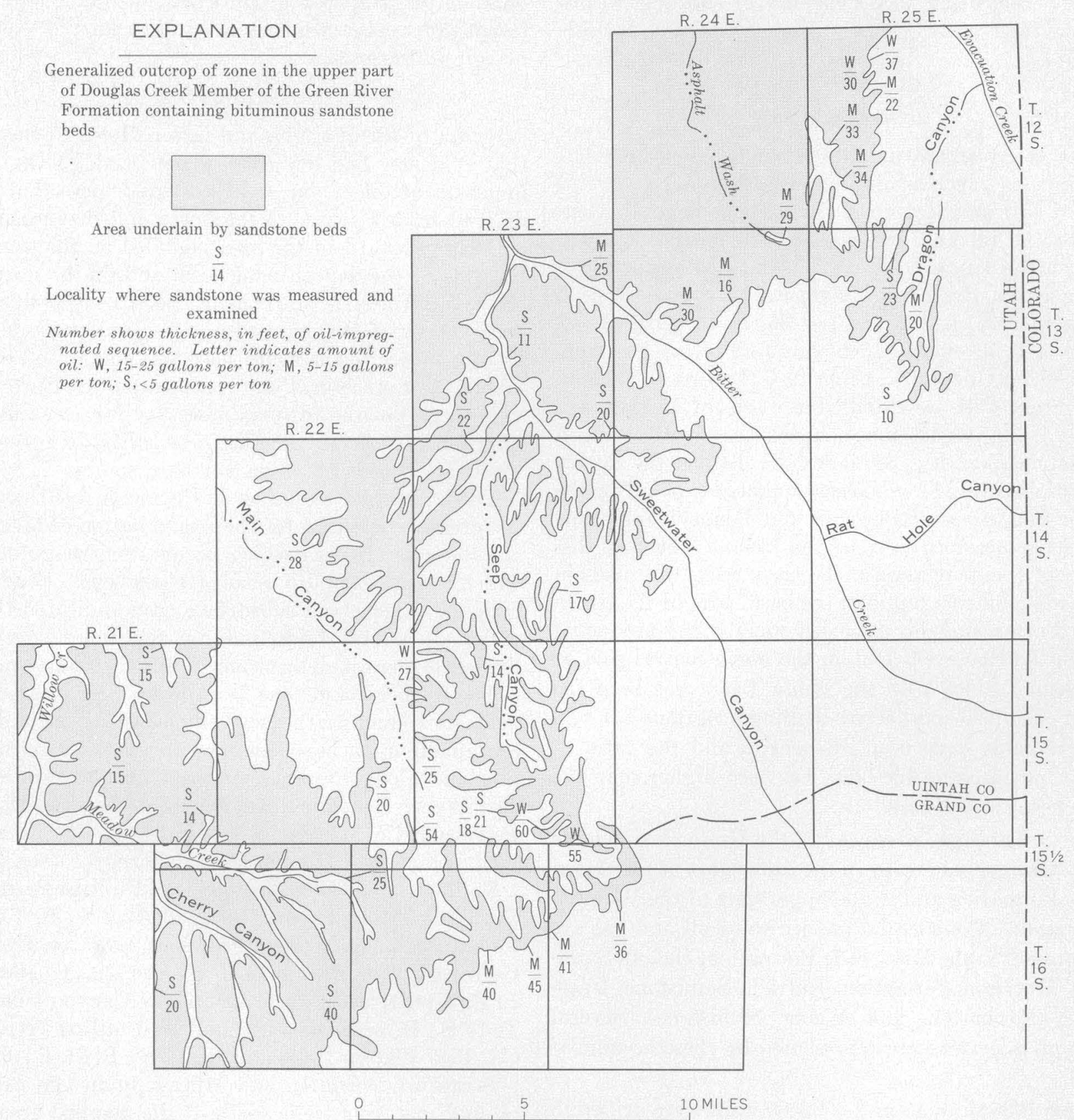

FIGURE 12.-Outcrop of zone in the Green River Formation containing bituminous sandstone beds.

Source of the bituminous material has not been determined. It is seemingly indigenous to the Green River Formation, although no likely source beds oceur adjacent to the impregnated sandstones. There is no evidence that it was derived from the fluid hydrocarbon which filled the gilsonite veins. The sandstone zone that is impregnated by bitumen in a large area southwest of Evacuation Creek is virtually barren where it is cut by the Black Dragon gilsonite vein. A few feet on either side of the vein the sandstone is impregnated but, with that exception, it is barren to the southwest for about half a mile. To the northeast the sandstone outcrop contains no bitumen. That structure controlled the bitumen accumulations is suggested by some inconclusive evidence. The highly impregnated sandstone in the P. R. Springs area lies along the crest of the Hill Creek structure, and the highly impregnated sandstones near Bitter Creek lie on, or near, the crests of small noses.

Owing to the variations in the impregnation of the 
sandstone beds and to the absence of subsurface control, the reserves of bitumen in sandstone were not calculated.

\section{OIL AND GAS}

DEVELOPMENT

The variety and abundance of surface occurrences of hydrocarbons, such as bituminous sandstones and veins of solid hydrocarbons, long ago drew geologists' attention to the oil and gas possibilities of the Tertiary rocks in the Uinta Basin. The first exploratory well in the basin, drilled in 1900, was the John Pope 1 (Hansen, 1957, p. 165), in sec. 35, T. 15 S., R. 23 E. (table 5, this report). No shows of oil or gas were recorded for this well. From 1900 through 1948 many exploratory wells were drilled into beds of Tertiary age in the Uinta Basin, but none of these wells tapped commercial quantities of oil or gas. In 1948 the Equity Oil Co. discovered commercial quantities of oil in the Weber Sandstone of Permian and Pennsylvanian age in the northeastern part of the basin. The first discovery of commercial oil in Tertiary rocks was made in 1949 , when oil was found in the basal part of the Green River Formation; this discovery was the first producing well in the Roosevelt field, in the north-central part of the basin. Since 1949 the Uinta Basin has been the site of one of the most active drilling programs in Utah. Several fields have been discovered, and the ratio of producing wells to dry holes has been higher than the average for other areas.

Most oil and gas produced in the Uinta Basin comes from stratigraphic traps in the lower part of the Green River Formation and in the upper part of the Wasatch Formation. Commercial quantities of oil and gas are also present in the Mesaverde Formation, Dakota Sandstone, Morrison Formation, Entrada Sandstone, Phosphoria Formation, and Weber Sandstone. Several types of reservoirs are represented by these accumulations.

From 1900 through mid-1962, 80 wells were drilled in the mapped area (table 5). Of these 80 wells, 1 produced oil, 19 produced gas, and 60 were dry holes. The single oil well produced from the Wasatch Formation.
Most of the gas wells produce from Jurassic and Cretaceous rocks on anticlinal structures near the southern margin of the area.

\section{POSSIBIHITIES}

Strata of the Wasatch and Green River Formations that evidently had the greatest potential for the accumulation of oil or gas are those sandstones that were derived from a source to the north and that pinch out updip southward in the area bounded on the south by the axis of the depositional basin and on the north by the axis of the structural basin. Most beds of this type occur north of the mapped area. Sandstones derived from a source to the south may also contain oil or gas where their structural and stratigraphic features provide traps, but the features necessary for accumulation are probably not as common in beds having a southern source as in beds having a northern source.

The strata of Cretaceous and Jurassic age that have the greatest potential for the accumulation of oil or gas are those sandstones which occur along anticlines or which pinch out updip in impervious beds. Studies of both the surface and subsurface have indicated the location of several folds, but too few holes have been drilled to permit delineation of stratigraphic traps.

The Weber Sandstone is a prolific oil producer in fields north and northeast of the mapped area and may contain oil or gas in the mapped area near its southward pinchout along the flank of the Uncompahgre uplift. The Weber Sandstone was penetrated in the Phillips Petroleum Co. Watson B-1 (sec. 34, T. 9 S., R. 25 E., Utah), the Argo Oil Co. Govt. Chorney 1 (sec. 35, T. 1 N., R. 103 W., Colorado), and the Phillips Petroleum Co. Hells Hole Canyon 1 (sec. 12, T. 2 S., R. 104 W., Colorado). The Weber was absent, however, from the Carter Oil Co. Minton State 1 (sec. 32, T. 14 S., R. 20 E., Utah), the Texaco, Inc., Fence Canyon 1 (sec. 36, T. 15 S., R. 22 E., Utah), and the Phillips Petroleum Co. Two Waters 1 (sec. 22, T. 14 S., R. 25 E., Utah).

Strata of Devonian and Mississippian age produce oil and gas from wells south of the mapped area near the southwest flank of the Uncompahgre uplift. Because of the small number of deep wells, little is known about pre-Pennsylvanian rocks in the mapped area. 
TABLE 5.-Exploratory wells drilled within the mapped area

[Interval from surface to contour datum (Mahogany bed): +, surface above datum; -, surface below datum. C, Center; KB, Kelly bushing; Gr, Ground; DF, Derrick floor; RB, Rotary base; MCFG PD ,1,000
cu ft of gas per day]

\begin{tabular}{|c|c|c|c|c|c|c|c|c|}
\hline \multirow[b]{2}{*}{ Well } & \multicolumn{3}{|l|}{ Location } & \multirow{2}{*}{$\begin{array}{c}\text { Elevation } \\
\text { (feet) }\end{array}$} & \multirow{2}{*}{$\begin{array}{l}\text { Approximate } \\
\text { interval from } \\
\text { surface to con- } \\
\text { tour datum } \\
\text { (feet) }\end{array}$} & \multirow{2}{*}{$\begin{array}{l}\text { Total } \\
\text { depth } \\
\text { (feet) }\end{array}$} & \multirow[b]{2}{*}{ Oldest rock penetrated } & \multirow[b]{2}{*}{ Remarks } \\
\hline & Section & $\begin{array}{l}\text { Town- } \\
\text { ship }\end{array}$ & Range & & & & & \\
\hline \multicolumn{9}{|c|}{ Colorado } \\
\hline Argo Oil Co. Govt. Chorney 1... & NE1/4SE1/4NW1/435. & $1 \mathrm{~N}$. & $103 \mathrm{w}$. & $5,423 \mathrm{~KB}$ & $-1,650$ & 10,270 & Weber Sandstone. & Plugged and abandoned. \\
\hline Roy M. Johnson Govt. Warner 1. . & NW1/NEL/SEY//4 7 & $2 \mathrm{~s}$. & $103 \mathrm{w}$. & $7,054 \mathrm{Gr}_{\mathrm{H}}$ & -980 & 3,349 & Mancos Shale..... & Do. \\
\hline Roy M. Johnson Govt. Warner 2... & NW1/4NE1/4NE1/4 $7 .$. & $2 \mathrm{~s}$. & $103 \mathrm{~W}$. & 7,077 Gr.... & $-1,020$ & 2,862 & Mancos(?) Shale_. & Do. \\
\hline Alamo Corp. Lower Horse Draw 6.. & CNW1/4SE1/4 $16 \ldots$ & $2 \mathrm{~S}$. & $103 \mathrm{~W}$ & 6,450 $\mathrm{Gr}(?)$ & $-1,600$ & & & Tight hole. \\
\hline Alamo Corp. Lower Horse Draw $5 \ldots$ & CNW1/4SE1/417 & $2 \mathrm{~s}$. & $103 \mathrm{~W}$. & 6,593 KB.... & $-1,420$ & 3,388 & Mancos Shale.... & Plugged and abandoned. \\
\hline Roy M. Johnson Govt. Barrows 2... & NE1/4SE1/4SE1//11.. & $2 \mathrm{~s}$. & $104 \mathrm{~W}$. & 6,634 Gr.... & $-1,110$ & 2,800 & -....do............. & Do. \\
\hline Roy M. Johnson Govt. Barrows 1.. & CSE $/ 412 \ldots$ & $2 \mathrm{~s}$. & $104 \mathrm{~W}$ & $6,784 \mathrm{Gr}_{-}$ & $-1,040$ & 2,495 & Mesaverde Formation. & $\begin{array}{l}\text { Initial flow } 11,200 \text { MCFGPD from Mesaverde } \\
\text { Formation. }\end{array}$ \\
\hline Phillips Petroleum Co. Hells Hole Canyon 1..- & NE1/4SW1/4NW1/4 12.. & $2 \mathrm{~s}$. & $104 \mathrm{~W}$. & $6,905 \mathrm{~KB} .$. & $-1,000$ & 12,524 & Sawatch Quartzite.. & Plugged and abandoned. \\
\hline Phillips Petroleum Co. Hells Hole Canyon B-1 & CSW $1 / 2$ NEY/4 $12 \ldots$ & $2 \mathrm{~S}$. & $104 \mathrm{w}$ & 6,976 KB.. & -970 & 7,913 & Entrada Sandstone... & Do. \\
\hline Phillips Petroleum Co. Hells Hole Can yon C-1_. & CNE1/4 13 & 2 S. & $104 \mathrm{w}$ & $7,328 \mathrm{DF}$ & -550 & 3,320 & Mancos Shale & Do. \\
\hline Alamo Corp. Missouri Creek 28-1............ & $\mathrm{SE} 1 / 4 \mathrm{NW} / 4 \mathrm{SW} 1 / 428$ & 3 s. & $103 \mathrm{~W}$. & $6,228 \mathrm{Gr} \ldots$ & $-1,620$ & 6,910 & Entrada Sandstone..... & $\begin{array}{l}\text { Initial flow } 414 \text { MCFGPD (34-in. choke) from } \\
\text { Morrison Formation. }\end{array}$ \\
\hline Continental Oil Co. Govt. Minton 2... & NE1/4NE1/4SE1/430 30. & 3 s. & $103 \mathrm{~W}$. & $6,176 \mathrm{RB}$ & $-1,580$ & 4,052 & Mancos Shale. & Plugged and abandoned. \\
\hline
\end{tabular}

Utah

\begin{tabular}{|c|c|c|c|c|c|}
\hline 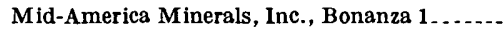 & $N W 1 / 424$ & $\theta \mathrm{s}$ & & $24 \mathrm{E}$. & $5,469 \mathrm{DF}$ \\
\hline Roy M. Johnson Bonanza 1... & SW1/4SW1/4SW1/4 27. & $9 \mathrm{~s}$ & s. & $25 \mathrm{E}$. & $5,050 \mathrm{Gr}(?)$ \\
\hline Phillips Petroleum Co. Watson B-1. & SW $1 / 4$ NW1/4NW1/4 34 & $9 \mathrm{~s}$ & s. & $25 \mathrm{E}$. & $5,048 \mathrm{DF}$ \\
\hline Roy M. Johnson Watson 3 & NW1/4NW1/4NW1/434. & & s. & $25 \mathrm{E}$. & $5,026 \mathrm{DF}$. \\
\hline Johnson and Bunn Watson 4 & SW1/4SW1/4NW1/434 & $9 \mathrm{~s}$ & s. & & $5,015 \operatorname{Gr}(?)$ \\
\hline Continental Oil Co. Watson 2. & $\mathrm{SW} / 4 \mathrm{SW} / / 414$ & $10 \mathrm{~s}$ & s. & $24 \mathrm{E}$. & $5,247 \mathrm{Gr}$ \\
\hline Continental Oll Co. Watson 1. & $\mathrm{SW1/4SW1/424}$ & & & & $5,417 \mathrm{Gr}$. \\
\hline Oil, Inc., Bonanza 2. & SW1/4NE1/4SE1/422. & $10 \mathrm{~s}$ & s. & $25 \mathrm{E}$. & $5,625 \mathrm{DF}$. \\
\hline Oil, Inc., $\mathrm{I}$ & $\mathrm{NW} 1 / 4 \mathrm{NW} 1 / 4 \mathrm{NE} 1 / 435$ & $10 \mathrm{~S}$ & s. & & $5,723 \mathrm{Gr}$ \\
\hline Shamrock 0 & NW $1 / 4$ NW1/4NW1/423. & 118 & & & $5,795 \mathrm{Gr}$ \\
\hline Belco Petroleum Co. Great Yellowstone 1. & $\mathrm{SE} / 4 \mathrm{SE} / 429 \ldots$ & $11 \mathrm{~s}$ & s. & $20 \mathrm{E}$. & $5,564 \mathrm{~KB}$ \\
\hline Ohio Oil Co & $\mathrm{SW} 1 / 4 \mathrm{SW} / / 2 \mathrm{NE} 1 / 28$ & $11 \mathrm{~s}$ & s. & $21 \mathrm{E}$. & 5, $524 \mathrm{DF}$. \\
\hline Fee 1... & $\mathrm{NE} / 4 \mathrm{SW} / 45 \ldots$ & $11 \mathrm{~s}$ & s. & $25 \mathrm{E}$. & $5,533 \mathrm{Gr}$ \\
\hline Continental Oil & $\mathrm{SE} 3 / \mathrm{SW} 1 / 422$ & & s. & $25 \mathrm{E}$. & $5,722 \mathrm{Gr}$ \\
\hline H. M. I & $N W Y / 4 W 1 / 426$ & $12 \mathrm{~s}$ & s. & $20 \mathrm{E}$. & $5,638 \mathrm{Gr}$. \\
\hline Delhi-Taylor Oil Corp. & SW1/4NE1/4 15 & & s. & $21 \mathrm{E}$. & $6,240 \mathrm{DF}$ \\
\hline Delhi & SW1/ & $12 \mathrm{~s}$ & s. & $21 \mathrm{E}$. & $6,187 \mathrm{~K}$ \\
\hline Delhi-Taylor Oll Corp. 1-22. & $8 W 1 / 4 N E 1 / 42$ & $12 \mathrm{~s}$ & s. & $21 \mathrm{E}$. & $6,375 \mathrm{~KB}$ \\
\hline Delhi & NW3, & $12 \mathrm{~s}$ & & $22 \mathrm{E}$. & $6,037 \mathrm{~K}$ \\
\hline Sincla & $\mathrm{sw} / 4 \mathrm{SW}$ & $12 \mathrm{~s}$ & s. & $22 \mathrm{E}$. & 6, $194 \mathrm{Gr}_{\text {- }}$ \\
\hline Alamo Corp. Oll Springs 2 & NE1/4SW1/43 3 & $12 \mathrm{~s}$ & s. & 24 E. & $5,900 \mathrm{DF}$ \\
\hline Sky-Hi Oll Co. O & $\mathrm{NW} / 4 \mathrm{NW} / 4$ & & s. & $24 \mathrm{E}$. & 6,18 \\
\hline Con & SEY/SW1/4SEY//4 15 & $12 \mathrm{~s}$ & s. & $24 \mathrm{E}$. & 6, $291 \mathrm{I}$ \\
\hline Continental Oil Co. $\mathrm{O}$ & NW1/4SW1/4 18 & $12 \mathrm{~s}$ & s. & $25 \mathrm{E}$. & 6,172 Gr. \\
\hline & NW3 & $12 \mathrm{~s}$ & s. & $25 \mathrm{E}$. & 6,17 \\
\hline Contine & $\mathrm{SW} / 4 \mathrm{NW} / 4 \mathrm{SW}$ & $12 \mathrm{~s}$ & s. & 25 & $6,184 \mathrm{Gr}$ \\
\hline
\end{tabular}

\begin{tabular}{|c|c|c|}
\hline$+1,110$ & 7,215 & Mancos Shale \\
\hline-400 & 2,080 & Wasatch Formation. \\
\hline-440 & 13,538 & Mississippian. \\
\hline-420 & 1,252 & Wasatch Formation. \\
\hline-500 & 1,212 & ....do.. \\
\hline+840 & 3,315 & $\ldots$.... do \\
\hline+700 & 4,249 & Mesaverde Formation. \\
\hline$-1,030$ & 4,524 & Mancos Shale. \\
\hline$-1,250$ & 3,985 & ..do.. \\
\hline$+1,350$ & 5,487 & Wasatch Formation. \\
\hline+800 & 8,827 & Mesaverde Formation. \\
\hline$+1,260$ & 5,520 & Wasatch Formation. \\
\hline+320 & 839 & Green River Formation.. \\
\hline-170 & 6,300 & Mancos Shale... \\
\hline+310 & 7,725 & \\
\hline+950 & 6,524 & Mesaverde Formation \\
\hline+940 & 6,205 & ...do. \\
\hline+940 & 8, 294 & Mancos Shale \\
\hline+770 & 5,821 & Mesaverde Formation. \\
\hline+600 & 7,400 & Mancos Shale_ \\
\hline+240 & 5,734 & -..._do_.. \\
\hline+80 & 5,270 & -..do. \\
\hline+300 & 4,350 & Mesaverde I \\
\hline-80 & 2,667 & Wasatch Formation... \\
\hline-80 & 4,170 & Mesaverde Formation.. \\
\hline-120 & 3,498 & \\
\hline
\end{tabular}

Plugged and abandoned.

Old well drilled deeper; plugged and abandoned. Plugged and abandoned.

Plugged and
Do.
Do.

Do.

Do.

Do.

Do.

Do.

Do.

Do.

Tight hole.

Initial flow 3,569 MCFAPD (3/4-in. choke) from Wasatch Formation.

Temporarily abandoned.

Initial flow 6,800 MCFGPD from Wasatch Fornation.

Plugged and abandoned.

Do.

Initial flow 3,250 MCFGPD (11/4-in. choke) from Wasatch Formation.

Initial flow 180 MCFaPD from Mesaverde Formation.

Plugged and abandoned.

Plugged and abandoned. Skidded rig to location 2A.

lugged and abandoned. 
TABLE 5.-Exploratory wells drilled within the mapped area-Continued

\begin{tabular}{|c|c|c|c|c|c|c|c|c|}
\hline \multirow[b]{2}{*}{ Well } & \multicolumn{3}{|c|}{ Location } & \multirow{2}{*}{$\begin{array}{c}\text { Elevation } \\
\text { (feet) }\end{array}$} & \multirow{2}{*}{$\begin{array}{l}\text { Approximate } \\
\text { interval from } \\
\text { surface to con- } \\
\text { tour datum } \\
\text { (feet) }\end{array}$} & \multirow{2}{*}{$\begin{array}{c}\text { Total } \\
\text { depth } \\
\text { (feet) }\end{array}$} & \multirow[b]{2}{*}{ Oldest rock penetrated } & \multirow[b]{2}{*}{ Remarks } \\
\hline & Section & $\begin{array}{l}\text { Town- } \\
\text { shi p }\end{array}$ & Range & & & & & \\
\hline \multicolumn{9}{|c|}{ Utah-Continued } \\
\hline Alamo Corp. Oil Springs 1.................. & NW1/4SW1/4 $18 \ldots$ & & $25 \mathrm{E}$. & 6,296 DF.. & -80 & 4,869 & Mancos Shale. & Old well drilled deeper; plugged and abandoned \\
\hline H. M. Byllesby \& Co. Inc., Byllesby $2 \ldots$ & $\mathrm{NE} 1 / 4 \mathrm{SW} 1 / 45 \ldots$ & $13 \mathrm{~s}$. & $20 \mathrm{E}$. & 6,154 Gr... & +470 & 8,520 & Mancos (?) Shale. & Tight hole. \\
\hline Sunray Oil Co. Agency Draw $1 \ldots \ldots$ & NW $1 / 4$ SW1/412. & $13 \mathrm{~s}$. & $20 \mathrm{E}$. & $5,767 \mathrm{DF}$ & -30 & 7,316 & Mancos Shale & Plugged and abandoned. \\
\hline H. M. Byllesby \& Co. Inc., Byllesby 3.. & NW1/4SW1/423. & & & $6,127 \mathrm{Gr}$. & -20 & 6,918 & Mesaverde (?) Formation. & Initial gas flow not released. \\
\hline Sinclair Oil \& Gas Co. Uintah Oil Assoc. 1.. & CNW $1 / 4 N^{2} 1 / 48$ & & $21 \mathrm{E}$. & $5,945 \mathrm{Gr}$ & +180 & 7,433 & Mancos Shale & $\begin{array}{l}\text { Initial production } 20 \text { bbls of oil and } 80 \text { bbls of } \\
\text { water per day from Wasatch Formation. }\end{array}$ \\
\hline Continental Oll Co. Bull Canyon 1......... & SW $1 / 4 \mathrm{SE} 1 / 4 \mathrm{SW} 1 / 427 \ldots$ & $13 \mathrm{~s}$. & $21 \mathrm{E}$. & $5,672 \mathrm{Gr}$ & -700 & 4,215 & Mesaverde Formatio & Plugged and abandoned. \\
\hline Sinclair Oil \& Gas Co. Uintah 1-122........ & $\mathrm{NE} 1 / 4 \mathrm{SE} 1 / 418$ & $13 \mathrm{~s}$. & $22 \mathrm{E}$. & $6,039 \mathrm{Gr}$ & -100 & 6,500 & Mancos Shale. & Do. \\
\hline Woodward \& Co. McCook Ridge $1 \ldots$ & NW1/4NW1/425. & $13 \mathrm{~s}$. & $23 \mathrm{E}$. & $6,489 \mathrm{Gr}$ & +70 & 6,095 & ......do-... & Do. \\
\hline Skyline Oil Co. Preston M. Neilson 1.. & SW $1 / 4$ NE1/4 $26 \ldots$ & $13 \mathrm{~s}$. & $23 \mathrm{E}$. & $6.428 \mathrm{Gr}$ & +90 & 5,852 & do do d & Do. \\
\hline Continental Oil Co. Oil Springs 3 & $\mathrm{NW} / 4 \mathrm{NW} 1 / 4 \mathrm{NE} 1 / 415$ & $13 \mathrm{~s}$. & $24 \mathrm{E}$. & $6,661 \mathrm{DF}$ & +60 & 4,177 & Mesaverde Formation. & Do. \\
\hline $\begin{array}{l}\text { Pacific States Cast Iron Pipe Co. Wild Horse } \\
\text { Creek 1. }\end{array}$ & $\mathrm{SE} 1 / 4 \mathrm{SE} 1 / 425 \ldots$ & & $17 \mathrm{E}$. & 7,441 Gr... & +450 & 5,700 &.$---d o$ & Do. \\
\hline El Paso Natural Gas Co. Firewater Canyon 1.. & $\mathrm{SE} 1 / 4 \mathrm{SE} 1 / 41 \ldots$ & $14 \mathrm{~s}$. & $18 \mathrm{E}$. & $7,050 \mathrm{Gr}$ & +430 & 5,513 & ...do.. & Do. \\
\hline Castle Dale Oil Co. Hill Creek 1............ & $\begin{array}{l}\text { (?) } 24 \text { (Not shown on } \\
\text { pl. 1.) }\end{array}$ & $14 \mathrm{~s}$. & $19 \mathrm{E}$. & $6,300 \mathrm{Gr}(?)$ & -670 & 900 & Wasatch Formation ... & Do. \\
\hline Castle Dale Oil Co. Hill Creek 2. & $\begin{array}{l}\text { (?) } 24 \text { (Not shown on } \\
\text { pl. 1.) }\end{array}$ & $14 \mathrm{~s}$. & $19 \mathrm{E}$. & $6,275 \operatorname{Gr}(?)$ & -670 & 1,170 & ....do. & Do. \\
\hline Midwest Refining Co. Cannon 1. & $\mathrm{SW} 1 / 4 \mathrm{SW} 1 / 4 \mathrm{SW} 1 / 429$ & $14 \mathrm{~s}$. & $20 \mathrm{E}$ & 7,475 $\mathrm{Gr}(?)$ & +420 & 26 & Green River Formation & Do. \\
\hline Midwest Refining Co. Evans 1... & $\mathrm{SE} 1 / 4 \mathrm{SE} 1 / 4 \mathrm{SE} 1 / 430$ & $14 \mathrm{~s}$. & $20 \mathrm{E}$ & 7,475 Gr(?). & +420 & 20 & ..... do & Do. \\
\hline Utah Oil and Refining Co. Hill Creek 1 & $\mathrm{SE} 1 / 4 \mathrm{NW} / 432 \ldots$ & $14 \mathrm{~s}$. & $20 \mathrm{E}$. & $7,500 \mathrm{Gr}(?)$ & +420 & 2,150 & Wasatch Formation.. & Do. \\
\hline Carter Oil Co. Minton State 1 & $\mathrm{NE} 1 / 4 \mathrm{SE} 1 / 432 \ldots$ & $14 \mathrm{~s}$. & $20 \mathrm{E}$ & 7,489 Gr.... & +420 & 12,897 & Precambrian & Do. \\
\hline Continental Oil Co. Bull Canyon 2. & $\mathrm{SE} 1 / 4 \mathrm{SE} 1 / 49$ & $14 \mathrm{~S}$. & $21 \mathrm{E}$ & $5,885 \mathrm{Gr}$ & -740 & 4,205 & Mesaverde Formation. & Do. \\
\hline Skyline Oil Co. Sweetwater Creek $2 \ldots$ & $\mathrm{SW} 1 / 4 \mathrm{NE} 1 / 414 \ldots$ & $14 \mathrm{~s}$. & $22 \mathrm{E}$ & 6, $955 \mathrm{DF}$ & -40 & 9,421 & Morrison Formation... & Temporarily abandoned. \\
\hline Phillips Petroleum Co. Two Waters 1. & SW $1 / 4 \mathrm{SW} 1 / 422$ & $14 \mathrm{~s}$. & $25 \mathrm{E}$. & $7,099 \mathrm{RB}_{-}$ & $-1,200$ & 9,375 & Precambrian quartzite. & Plugged and abandoned. \\
\hline Alpine Oil Co. Winter Ridge 1 & CNE $1 / 4 \mathrm{SW}^{1 / 4} 22 \ldots$ & $15 \mathrm{~s}$. & $21 \mathrm{E}$ & $7,404 \mathrm{~KB}$ & +150 & 10,060 & Morrison(?) Formation. & Old well drilled deeper; temporarily abandoned. \\
\hline Texaco, Inc., Fence Canyon 2.......... & $\mathrm{NE} 1 / 4 \mathrm{SE} 1 / 426 \ldots$ & $15 \mathrm{~S}$. & $22 \mathrm{E}$ & $7,029 \mathrm{~KB}$ & -600 & 8,585 & Morrison Formation.... & $\begin{array}{l}\text { Initial flow } 600 \text { MCFGPD (11/4-in. choke) from } \\
\text { Morrison Formation and } 1,175 \text { MCFGPD } \\
\text { (11/1/-in. choke) from Lower Cretaceous. }\end{array}$ \\
\hline Texaco, Inc., Fence Canyon 1 & $\mathrm{NE} 1 / 4 \mathrm{SE} 1 / 436$ & $15 \mathrm{~s}$. & $22 \mathrm{E}$. & $7,692 \mathrm{Gr}$ & -120 & 10,348 & Precambrian & Initial flow 3,100 MCFGPD from Dakota \\
\hline Mountain Fuel Supply Co. Main Canyon $1 .$. & $\mathrm{NE}_{1 / \mathrm{SE}} 1 / 28$ & & $23 \mathrm{E}$. & 7,799 DF_... & -150 & 9,051 & Entrada Sandstone & $\begin{array}{l}\text { Sandstone. } \\
\text { Plugged and abandoned. }\end{array}$ \\
\hline John Pope 1 & $\mathrm{NE} / / \mathrm{SE} 1 / 4 \mathrm{NW} 1 / 435$ & $15 \mathrm{~S}$. & $23 \mathrm{E}$. & $8,100 \mathrm{Gr}(?)$ & -100 & 1,000 & Wasatch Formation. & Do. \\
\hline Texaco, Inc., Fence Canyon 3............ & $\mathrm{SW} 1 / 4 \mathrm{SE} 1 / 433 \ldots$ & $151 / 2 \mathrm{~s}$. & $23 \mathrm{E}$. & $7,516 \mathrm{~KB} \ldots$ & -400 & 8,750 & Entrada Sandstone... & $\begin{array}{l}\text { Initial flow } 877 \text { MCFGPD (1/2-in. choke) from } \\
\text { I.ower Cretaceous. }\end{array}$ \\
\hline Superior Oil Co. Moon Ridge 31-15 & CNW $1 / 4$ NE $1 / 415$. & $16 \mathrm{~s}$. & $21 \mathrm{E}$. & $7,653 \mathrm{~KB}$. & +450 & 10,297 & Morrison Formation. & Temporarily abandoned. \\
\hline $\begin{array}{l}\text { Sunray Mid-Continent Oil Co. Diamond } \\
\text { Ridge } 4 .\end{array}$ & NW $1 / 4$ SE1/436....... & $16 \mathrm{~s}$. & $22 \mathrm{E}$. & $6,861 \mathrm{~KB} \ldots$ & $-1,070$ & 8,370 & Entrada Sandstone. ... & Do. \\
\hline Tidewater Oil Co. Horse Point $1 \ldots \ldots \ldots \ldots$ & NW1/4NE1/414. & $16 \mathrm{~s}$. & $23 \mathrm{E}$. & $8,355 \mathrm{DF}$. & -20 & 3,108 & Mesaverde Formation.... & Plugged and abandoned; junk in hole. \\
\hline Tidewater Oil Co. Horse Point 1-X... & NW1/4NE1/4 14 & $16 \mathrm{~s}$. & $23 \mathbf{E}$ & $8,367 \mathrm{DF} \ldots \ldots$ & -20 & 8,774 & Entrada Sandstone. ..... & $\begin{array}{l}\text { Initial flow } 1,025 \text { MCFGPD (11/4-in. choke) } \\
\text { from Dakota Sandstone. }\end{array}$ \\
\hline R. C. Underwood Seagull 1.. & SE1/4NE1/4 $13 \ldots$ & $16 \mathrm{~s}$. & $24 \mathrm{E}$ & 6,858 KB... & $-1,900$ & 6,050 & Morrison Formation... & Initial flow 3,025 MCFGPD (1/2-in. choke) \\
\hline R. C. Underwood Murphy 1-16 & NE1/4SW1/4 16. & $16 \mathrm{~s}$. & & $6,897 \mathrm{~KB} \ldots . .$. & $-1,800$ & 7,205 & Morrison (?) Formation... & $\begin{array}{l}\text { from Cedar Mountain Formation. } \\
\text { Plugged and abandoned. }\end{array}$ \\
\hline Shamrock Oil \& Gas Corp. East Canyon 2. & SW1/4NE1/4 24 & $16 \mathrm{~s}$. & $24 \mathrm{E}$ & $6,594 \mathrm{Gr}$ & $-2,100$ & 6,217 & .....do do & $\begin{array}{l}\text { Initial flow 4,193 MCFGPD from Morrison } \\
\text { Formation. }\end{array}$ \\
\hline Belco Petroleum Co. Jim Creek 1...... & SW $1 / 4$ SE $1 / 410 \ldots$ & $16 \mathrm{~S}$. & $25 \mathrm{E}$. & $6,599 \mathrm{Gr} \ldots \ldots$ & $-1,900$ & 5,725 & Morrison Formation... & Initial flow 612 MCFGPD (58-in. choke) from \\
\hline
\end{tabular}




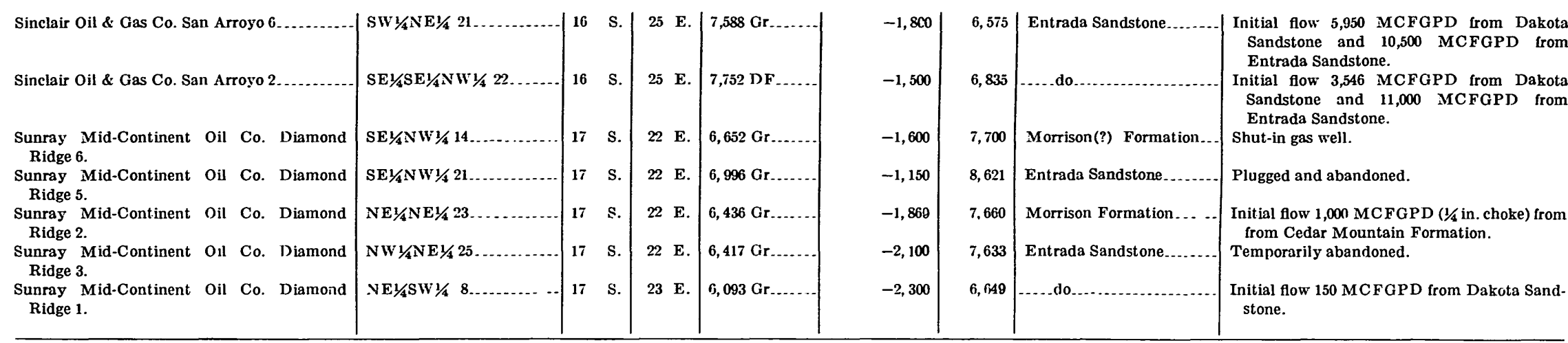




\section{REFERENCES}

Abbott, Ward, 1957, Tertiary of the Uinta Basin [Utah], in Intermountain Assoc. Petroleum Geologists Guidebook 8th Ann. Field Conf., Geology of the Uinta Basin: p. 102-109.

Abraham, Herbert, 1945, Asphalts and allied substances, their occurrence, modes of production, uses in the arts and methods of testing: 5th ed., New York, D. Van Nostrand Co., v. $1,887 \mathrm{p}$.

Adelman, F. L., Bacigalupi, C. M., and Momyer, F. F., 1960, Final report on the Pinot experiment: California Univ. Lawrence Radiation Lab. Rept. UCRL-6274, $21 \mathrm{p}$.

Bell, K. G., 1960, Uranium and other trace elements in petroleums and rock asphalts: U.S. Geol. Survey Prof. Paper 356-B, 21 p. [1961].

Blake, W. P., 1885, Uintahite, a new variety of asphaltum from the Uinta Mountains, Utah : Eng. Mining Jour., v. 40, p. 431.

Bradley, W. H., 1926, Shore phases of the Green River formation in northern Sweetwater County, Wyoming: U.S. Geol. Survey Prof. Paper 140-D, 11 p.

1929, Algae reefs and oolites of the Green River Formation: U.S. Geol. Survey Prof. Paper 154-G, 21 p. [1930].

1930, The varves and climate of the Green River epoch : U.S. Geol. Survey Prof. Paper 158-E, 24 p.

1931, Origin and microfossils of the oil shale of the Green

River formation of Colorado and Utah: U.S. Geol. Survey Prof. Paper 168, $58 \mathrm{p}$.

1948, Limnology and the Eocene lakes of the Rocky Mountain region: Geol. Soc. America, Bull., v. 59, no. 7, p. 635-648.

- 1964, Geology of Green River Formation and associated Eocene rocks in southwestern Wyoming and adjacent parts of Colorado and Utah : U.S. Geol. Survey Prof. Paper 496-A, 86 p. [1965].

Cashion, W. B., 1957, Stratigraphic relations and oil shale of the Green River Formation in the eastern Uinta Basin [Utah], in Intermountain Assoc. Petroleum Geologists Guidebook 8th Ann. Field Conf., Uinta Basin: p. 131-135. 1959, Geology and oil-shale resources of Naval Oil-Shale Reserve No. 2, Uintah and Carbon Counties, Utah: U.S. Geol. Survey Bull. 1072-0, 41 p. [1960].

-1961, Potential oil-shale reserves of the Green River Formation in the southeastern Uinta Basin, Utah and Colorado, in Short papers in the geologic and hydrologic sciences: U.S. Geol. Survey Prof. Paper 424-C, p. C22-C24. 1964, Other bituminous substances, in Mineral and water resources of Utah: Utah Geol. and Mineralog. Survey Bull. 73, p. 63-70.

Cashion, W. B., and Brown, J. H., Jr., 1956, Geology of the Bonanza-Dragon oil-shale area, Uintah County, Utah, and Rio Blanco County, Colorado: U.S. Geol. Survey Oil and Gas Inv. Map OM-153.

Culbertson, W. C., 1962, Laney Shale Member and Tower Sandstone Lentil of the Green River Formation, Green River area, Wyoming, in Short papers in geology and hydrology: U.S. Geol. Survey Prof. Paper 450-C, p. C54-C57.

Dane, C. H., 1954, Stratigraphic and facies relationships of upper part of Green River formation and lower part of Uinta formation in Duchesne, Uintah, and Wasatch Counties, Utah: Am. Assoc. Petroleum Geologists Bull., v. 38, no. 3, p. $405-425$.

1955, Stratigraphic and facies relationships of the upper part of the Green River formation and the lower part of the Uinta formation in Duchesne, Uintah, and Wasatch Counties, Utah: U.S. Geol. Survey Oil and Gas Inv. Chart OC-52.
Donnell, J. R., 1957, Preliminary report on oil-shale resources of Piceance Creek basin, northwestern Colorado: U.S. Geol. Survey Bull. 1042-H, p. 255-271.

1961, Tertiary geology and oil-shale resources of the Piceance Creek basin between the Colorado and White Rivers, northwestern Colorado: U.S. Geol. Survey Bull. 1082-L, $57 \mathrm{p}$.

Eldridge, G. H., 1896, The uintaite (gilsonite) deposits of Utah, in Walcott, C. D., U.S. Geol. Survey 17th Ann. Rept., pt. 1: p. 909-949.

1901, The asphalt and bituminous rock deposits of the United States, in Walcott, C. D., U.S. Geol. Survey 22d Ann. Rept., pt. 1: p. 209-452.

Endlich, F. M., 1878, Report on the geology of the White River district, in Hayden, F. V., U.S. Geol. and Geog. Survey Terr. 10th Ann. Rept. : p. 61-131.

Erickson, R. L., Myers, A. T., and Horr, C. A., 1954, Association of uranium and other metals with crude oil, asphalt, and petroliferous rock: Am. Assoc. Petroleum Geologists Bull., v. 38 , no. 10 , p. $2200-2218$.

Graham, E. H., 1937, Botanical studies in the Uinta Basin of Utah and Colorado: Pittsburgh, Carnegie Mus. Annals, v. $26,432 \mathrm{p}$.

Guthrie, Boyd, 1938, Studies of certain properties of oil shale and shale oil : U.S. Bur. Mines Bull. 415, $159 \mathrm{p}$.

Hansen, G. H., 1957, History of drilling operations in Utah's Uinta Basin, in Intermountain Assoc. Petroleum Geologists Guidebook 8th Ann. Field Conf., Uinta Basin: p. 165-167.

Hayden, F. V., 1869, Review of leading groups, in U.S. Geol. Survey Terr. 3d Ann. Rept. : p. 189-192.

Hunt, J. M., Stewart, Francis, and Dickey, P. A., 1954, Origin of hydrocarbons of Uinta Basin, Utah: Am. Assoc. Petroleum Geologists Bull., v. 38, no. 8, p. 1671-1698.

Kay, J. L., 1934, The Tertiary formations of the Uinta Basin, Utah: Pittsburgh, Carnegie Mus. Annals, v. 23, p. 357-372. - 1957, The Eocene vertebrates of the Uinta Basin, Utah, in Intermountain Assoc. Petroleum Geologists Guidebook 8th Ann. Field Conf., Uinta Basin : p. 110-114.

Kilborn, G. R., 1964, New methods of mining and refining gilsonite, in Intermountain Assoc. Petroleum Geologists Guidebook 13th Ann. Field Conf., Guidebook to the geology and mineral resources of the Uinta Basin, Utah's hydrocarbon storehouse : p. 247-252.

Kinney, D. M., 1955, Geology of the Uinta River-Brush Creek area, Duchesne and Uintah Counties, Utah: U.S. Geol. Survey Bull. 1007, $185 \mathrm{p}$.

Kretchman, H. F., 1957, The story of gilsonite: Am. Gilsonite Co., $96 \mathrm{p}$.

Miller, D. F., 1956, The Hill Creek area [Utah], in Intermountain Assoc. Petroleum Geologists Guidebook 7th Ann. Field Conf., Geology and economic deposits of east-central Utah : p. 199-201.

Milton, Charles, and Eugster, H. P., 1959, Mineral assemblages of the Green River formation [Colo.-Utah-Wyo.], in Abelson, P. H., ed., Researches in geochemistry: New York, John Wiley \& Sons, Inc., p. 118-150.

Osborn, H. F., 1895, Fossil mammals of the Uinta beds [Utah] : Am: Mus. Nat. History Bull., v. 7, p. 71-105.

Peale, A. C.; 1878, Geological report on the Grand River district, in Hayden, F. V., U.S. Geol. and Geog. Survey Terr. Ann. Rept., 1876 : p. 161-185.

Picard, M. D., 1955, Subsurface stratigraphy and lithology of Green River formation in Uinta Basin, Utah: Am. Assoc. Petroleum Geologists Bull., v. 39, no. 1, p. 75-102. 
Picard, M. D., 1957, Green River and lower Uinta formationssubsurface stratigraphic changes in central and eastern Uinta Basin, Utah, in Intermountain Assoc. Petroleum Geologists Guidebook 8th Ann. Field Conf., Uinta Basin : p. 116-130.

Rapp, J. R., 1962, Roll in a sandstone lentil of the Green River Formation, in Short papers in geology and hydrology: U.S. Geol. Survey Prof. Paper 450-C, p. C85-C87.

Ray, R. G., Kent, B. H., and Dane, C. H., 1956, Stratigraphy and photogeology of the southwestern part of Uinta Basin, Duchesne and Uintah Counties, Utah : U.S. Geol. Survey Oil and Gas Inv. Map OM-171.

Spieker, D. M., 1946, Late Mesozoic and early Cenozoic history of central Utah : U.S. Geol. Survey Prof. Paper 205-D, $45 \mathrm{p}$.

Stagner, W. L., 1941, The paleogeography of the eastern part of the Uinta Basin during Uinta $B$ (Eocene) time: Pittsburgh, Carnegie Mus. Annals, v. 28, p. 273-308.

Stanfleld, K. E., Frost, I. C., McAuley, W. S., and Smith, H. N., 1951, Properties of Colorado oil shale: U.S. Bur. Mines Rept. Inv. $4825,27 \mathrm{p}$.

Stanfleld, K. E., Rose, C. K., McAuley, W. S., and Tesch, W. J:, Jr., 1954, Oil yields of sections of Green River oil shale in Colorado, Utah, and Wyoming, 1945-52: U.S. Bur. Mines Rpt. Inv. 5081, 153 p.
1957, Oil yields of sections of Green River oil shale in Colorado, 1952-54: U.S. Bur. Mines Rept. Inv. 5321, 132 p. Stanfield, K. E., Smith, J. W., and Trudell, L. G., 1964, Oil yields of sections of Green River oil shale in Utah, 1952-62: U.S. Bur. Mines Rept. Inv. 6420, 217 p.

Swain, F. M., 1956, Early Tertiary ostracode zones of Uinta Basin [Colo.-Utah], in Intermountain Assoc. Petroleum Geologists Guidebook 7th Ann. Field Conf., Geology and economic deposits of east-central Utah : p. 125-139.

White, C. A., 1878, Report on the geology of a portion of northwestern Colorado, in Hayden, F. V., U.S. Geol. and Geog. Survey Terr. Ann. Rept., 1876: p. 1-60.

Whittier, W. H., and Becker, R. C., 1962, Geologic map and sections of the bituminous sandstone deposits in the P. R. Springs area, Grand and Uintah Counties, Utah: U.S. Geol. Survey open-file report, $1 \mathrm{p}$.

Winchester, D. E., 1916, Oil shale in northwestern Colorado and adjacent areas: U.S. Geol. Survey Bull. 641-F, 60 p. [1917]. 1918, Oil shale of the Uinta Basin, northeastern Utah: U.S. Geol. Survey Bull. 691-B, 24 p. [1919].

Woodruff, E. G., and Day, D. T., 1915, Oil shale of northwestern Colorado and northeastern Utah: U.S. Geol. Survey Bull. 581-A, 21 p. 



\section{INDEX}

[Italic page numbers indicate major references]

\begin{tabular}{|c|c|}
\hline \multirow[t]{2}{*}{ A } & Page \\
\hline & \\
\hline \multicolumn{2}{|l|}{ 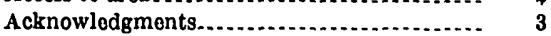 } \\
\hline \multicolumn{2}{|c|}{ 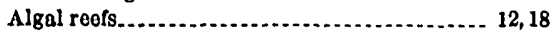 } \\
\hline Alluvial deposits, Quaternary ........... & 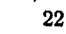 \\
\hline American Gllsonito Co., mining methods. & \\
\hline & \\
\hline
\end{tabular}

Badlands, Duchesne Rlver Formation........ Bitumin, source.

Bituminous sandstonos, Douglas Creek Mamber....................... 8

Black Dragon veln, gllsonite................... 35, 37

Black shalo facies, Douglas Creek Member... 10

Bonanza voln. See Indopendent-Tabor veln.

Burnt Timber Canyon, ofl shale suitable for strip mining near..................

C

Chimney Rock, tuffaceous dikes near........ Classiffcation of ofl-shale reserves.

Colluvial deposits, Quaternary..........

Colorado, exploration wells.

indicated oll-shale reserves, estimated at $15 \mathrm{gal}$ per ton.

ostimated at $25 \mathrm{gal}$ per ton.

estimatod at $30 \mathrm{gal}$ per ton.............

Inforred ofl-shale reserves, estimated at 15 gal per ton.

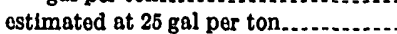

estimated at $80 \mathrm{gal}$ per ton

Colton Formation..............................

Cowboy vein, gllsonite.

Cralg, Colo., shlpping point

Dakota Bandstone, oll and gas................ Dopositional environment, Dougias Creek Member.

Evacuation Creak Member................ Garden Gulch Member.

Green River Formation.

Parachuto Creek Member ..................

Uinta Formation

Wasatch Formation.

Dovelopment of oil shale

Dikes, tuffaceous, Green River Formation...

Douglas Creek arch, Wasatch Formation near.

Douglas Creek Member, aquifer

bituminous sandstones.....................

black-shalo facles

characteristio topography as

discussion................................ 8,8

fossills......................................... 7,18

gllsonite velns........................... 31

oil shale..........................

stratigraphlo relations..................... 10

Drainage, study area......................... 4, 22

Duchesne River Formation

gilsonite veins.

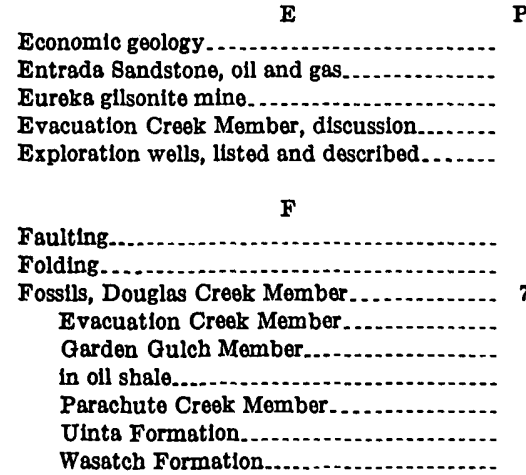

G

Garden Gulch Member

Qas. See Oll and gas.

Gilsonite, age relative to folding characteristics

classiflcation

mafor voins

mining and marketing

mining methods

occurrence

origin

reserves a

uses.

lsonite veins, characteristics

in joints.

major

relation to structure

Green River Formation

bituminous sandstones.

Douglas Creek Member.

Evacuation Creek Member

Garden Gulch Member.

gilsonite veins

Joint system.

kerogen-rich beds

lithology..

modiflcations of member boundaries

oll and gas.

Parachute Creek Momber

tufi beds.

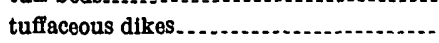

See also individual members.

Green River Shales, name change............ 7

Griggs, R. L., quoted........... 18, 18

Hill Creek anticline..........

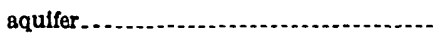

description.

I

Independent-Tabor vein, gilsonite

Industry In area.

Investigations, present and past..............

\begin{tabular}{|c|c|}
\hline Page & $\mathbf{J}, \mathbf{K}$ \\
\hline $\begin{array}{l}24 \\
40\end{array}$ & Joints. - \\
\hline 34 & Kerogen-rich beds, Green River Formation.... \\
\hline 16 & IIthologic characteristics. . . . \\
\hline 41 & weathering characteristics................ \\
\hline
\end{tabular}

\section{L}

Lake Uinta

Little Bonanza veln, gilsonite................. 34, 37

Little Emma veln, gilsonite................. 34

$\mathbf{M}$

McCook Ridge, ofl shale sultable for strip mining:-

Marker beds, Parachute Creek Member

Marketing, gilsonite.

Marketling, gllsonite.

Mahogany ledge.

Mahogany marker, tuff bed.

Mahogany oll-shale bed.

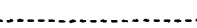

bedding-plane slippage....................

time plane.

Mahogany zone...

Marlstone. See O1l shale.

Mesaverde Formation, ofl and gas............ 40

Mining, gllsonite

requirements, oll shale.....................

Morrison Formation, oil and gas............. 40

Oll and gas.

Oll shale, assay procedures

characteristics.

color, relation to kerogen content. ........ 13

defined....................................... 13,24

development............... 24

Douglas Creek Member..................... 9,12

fossils in

Garden Gulch Member........ 12

mining requirements..................... 24

Parachute Creek Member.................. 19

potentíal reserves..................... 24, $27,28,29$

relation of specific gravity to oll content:-

weathering characteristics.

resources, Uinta Basin.

Oil traps, stratigraphic and structural features.

Origin of gllsonite-forming petroleum, theories.

$\mathbf{P}, \mathbf{Q}$

P.R. Springs area, bituminous sandstones.... Parachute Creek Member, bituminous sandstones.............................. discussion

fossils..............................................

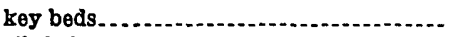

oil shale...

tuff beds

Petroleum, gllsonite-forming, theories on ori-

Phosphoris Formation, ofl and gas

Piceance Creek basin...................... 1

Plastlc flowage, sandstone beds............... $\quad 15$

tuff beds. 


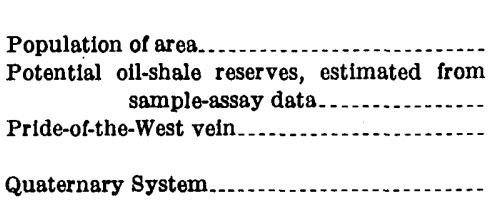

Page 25

$\mathbf{R}$

Rainbow vein, gilsonite.

Red beds, Wasatch Formation 34,37

Referen

Renegade Tongue, Wasatch Formation....... 4, Wasatch Formation, gilsonite veins....... 31

Reserves, gilsonite, estimated................. $\quad 97$

oll-shale, classification

methods of computing................. 25 potential.

summary 26

Sandstones, bituminous Source of sedime Duchesne Formation. Evacuation Creek Member.

Garden Gulch Member.

Green River Formation

Parachute Creek Member

Uinta Formation.

Wasatch Formation
Specific gravity of oil shale, relation to oil content.

Springs...

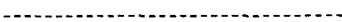

Stratigraphic section, south flank of Uinta Mountains.

Structure.

relation to bitumin accumulations

Uinta Basin

Sweetwater Canyon, bituminous sandstones near

Tertiary System, oil and gas

stratigraphy.

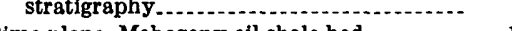

Tonnage estimates, Mahogany zone, 15 gallons oil per ton.

Mahogany zone, 25 gallons oil per ton 30 gallons oil per ton

Topography of area.

Tuff beds, Evacuation Creek Member.......

flowage conditions.

Green River Formation...................

Parachute Creek Member

$\mathrm{U}, \mathrm{V}$

Uinta Basin, description.

gilsonite mining.

structure.
Page

24

5

28

39

22

40
5

16

29

27

7

18

14
Uinta Formation, discussion

fossils

gilsonite veins.

Utah, exploration wells.

Indicated oil-shale reserves, estimated at $15 \mathrm{gal}$ per ton.

estimated at 25 gal per ton.............. estimated at $30 \mathrm{gal}$ per ton

inferred oll shale reserves, estimated at 15 gal per ton.......................... estimated at $25 \mathrm{gal}$ per ton............. estimated at $30 \mathrm{gal}$ per ton............

Vegetation.

Wagonhound vein, gilsonite

Wasatch Formation, basal conglomerate...... discussion.

fossils.

gilsonite veins.

oll and gas.

Water supply, study area.

Weathering, effect on oll shales.

Weaver-Colorado vein, gilsonite

Weber Sandstone, oll and gas.

Wells, exploration, mapped area

White River, rich ofl shale near
Page

19

21 